DOE /NASA CONTRACTOR REPORT

\title{
PRELIMINARY DESIGN PACKAGE FOR PROTOTYPE SOLAR HEATING SYSTEM
}

Prepared from documents furnished by

Honeywell, Inc.

Energy Resources Center

2600 Ridgway Parkway N.E。

Minneapolis, MN 44513

Under Contract NAS8-32093 with

National Aeronautics and Space Administration

George C. Marshall Space Flight Center, Alabama 35812

For the U.S. Department of Energy

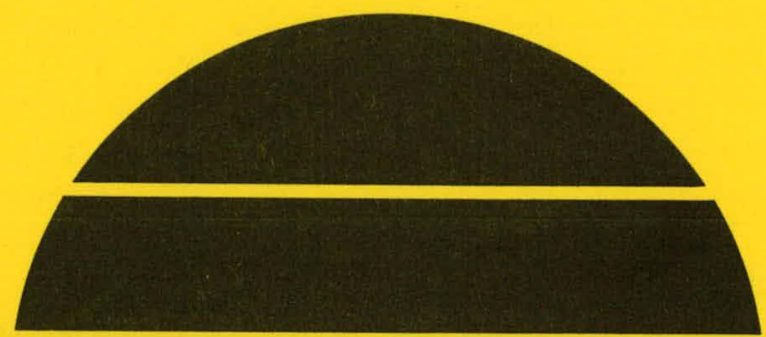

\section{U.S. Department of Energy}




\section{DISCLAIMER}

This report was prepared as an account of work sponsored by an agency of the United States Government. Neither the United States Government nor any agency Thereof, nor any of their employees, makes any warranty, express or implied, or assumes any legal liability or responsibility for the accuracy, completeness, or usefulness of any information, apparatus, product, or process disclosed, or represents that its use would not infringe privately owned rights. Reference herein to any specific commercial product, process, or service by trade name, trademark, manufacturer, or otherwise does not necessarily constitute or imply its endorsement, recommendation, or favoring by the United States Government or any agency thereof. The views and opinions of authors expressed herein do not necessarily state or reflect those of the United States Government or any agency thereof. 


\section{DISCLAIMER}

Portions of this document may be illegible in electronic image products. Images are produced from the best available original document. 
This report was prepared to document work sponsored by the Unfted States Government. Nelther the United States nor its agents the United States Department of Energy, the United States National Aeronautics and Space Adminlstration, nor any federsl employees, nor any of thefl contractors, sutcutractors or their employees, make any warranty, express or 1miflita, or assume any legal 11ability or responsibility for the accuiacy, completeness, or usefulness of any information, apparatus, product or procses disclosed, or represent that its use would not infringe privately owned rights. 
TECHNICAL REPORT ST ANDARD TITLE PAGE

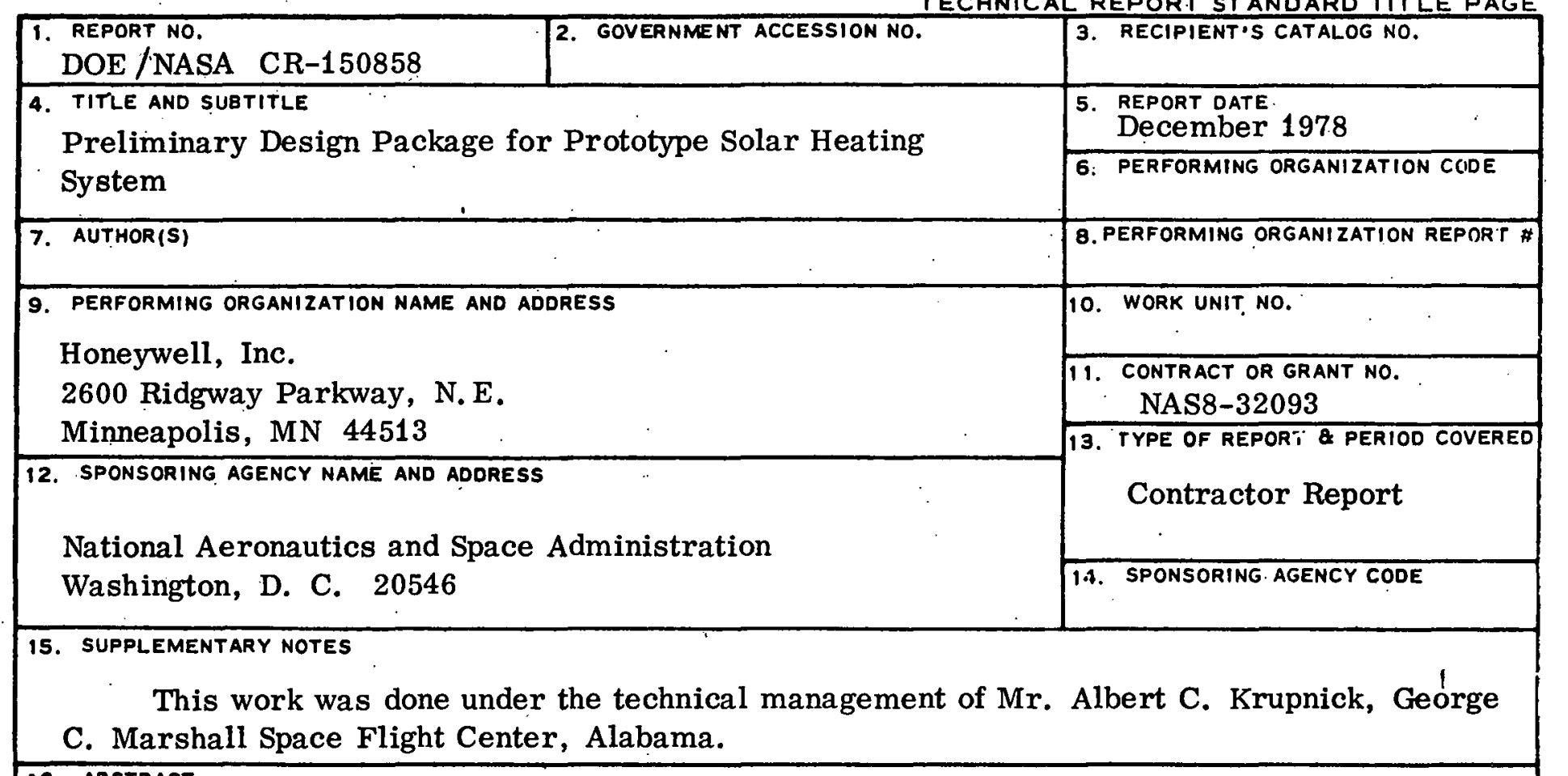

16. ABSTRACT

This report contains a summary of the preliminary analysis and design activity on solar heating systems. The analysis was made wi thout site specific data other than weather; therefore, the results indicate performance expected under these special conditions.

Major items in this report include system candidates, design a'pproaches, trade studies and other special data required to evaluate the preliminary analysis and design.

The program calls for the development and delivery of eight prototype solar heating and cooling systems for installation and operational test. Two $\dot{\sim}$ heating and six heating and cooling units will be delivered for Single Family Residences (SFR), Multi-Family Residences (MFR) and : commercial applications.

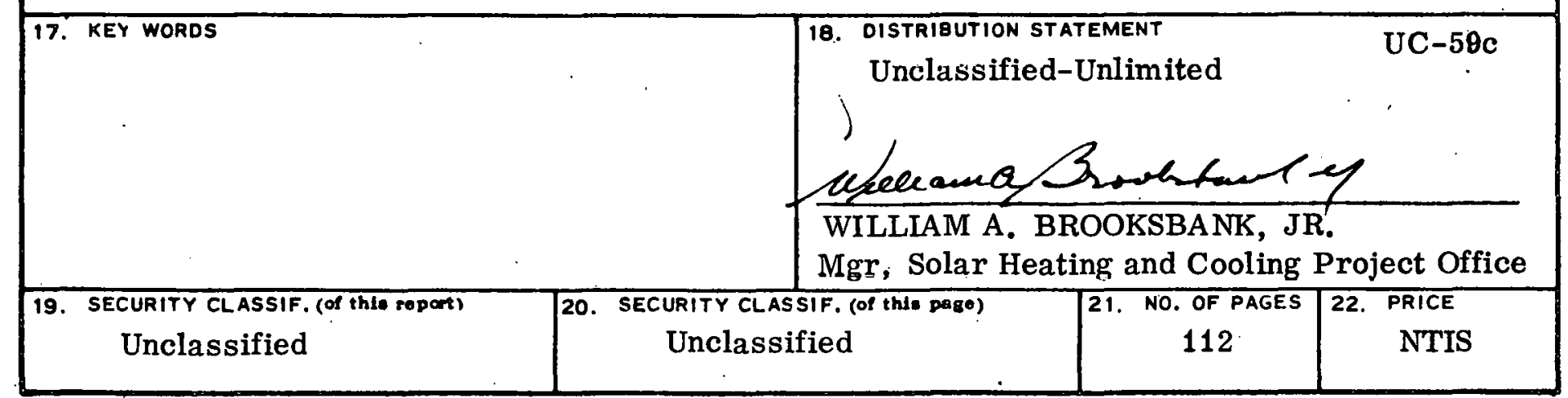


THIS PAGE

\section{WAS INTENTIONALLY LEFT BLANK}


1.0 Introduction

2.0 Market Analysis (This section is not included.)

3. 0 Systems Candidates

4. 0 Baseline System

5. $0 . \quad$ Trade - Studies

6.0 Recommended and Alternate Designs 6-1

7.0 Design \& Development Approaches 7-1

8. 0 Special Data for Preliminary Design Review 8-1

- Hazards Analysis 8-2

- Drawing List $8-10$

- Type I \& Type II Documents $8-12$

- Data for Prototype Design Review 8-13

- Data Acquisition SS Schedule 8-14

\begin{tabular}{l} 
- Symbology \\
\hline-15
\end{tabular}

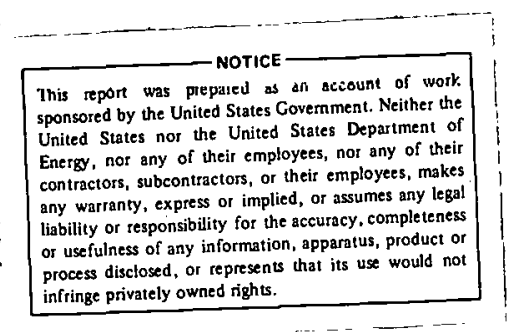


1.0 INTRODUCTION

The information presented in this document summarizes the Heating Systems preliminary analysis and design activity. It is provided to NASA/MSFC to prepare for the Heating Systems Preliminary Design Review to be held in Minneapolis, October $6 \& 7,1976$.

$1-1$ 


\subsection{MARKET ANALYSIS}

A market evaluation to supplement the design optimlzation studies is being prepared for the preliminary design review. This section is reserved for the market analysis data that will be submitted and presented at the preliminary design review meeting. 
3.0 System Candidates

3.1 Approach to the Selection of Delive rable Systems Honeywell's approach to the selection of solar-heating systems is illustrated in Figure 3-1. Primarily, the approach consists of two parallel efforts: identification of all candidate solar-heating subsystem components, and identification of subsystem constraints or evaluation criteria. The next step, preliminary subsystem selection, is designed to narrow the list of candidate subsystem components, using the defined constraints. It becomes evident that the major components for system selection are collector type, storage medium, and auxiliary heating method.

The next step in system selection incorporates subsystem trade-offs and economic trade-offs to further reduce the number of workable and economically desirable systems. The subsystems upon which trade-offs are examined are the following:

- Collector

- Storage

- Auxiliary energy

- Working fluids

- Supplementary elements such as controls, piping, pumps, etc.

The economic analysis is made using methods which incorporate life cycle costing techniques to establish the most economical solar system. 


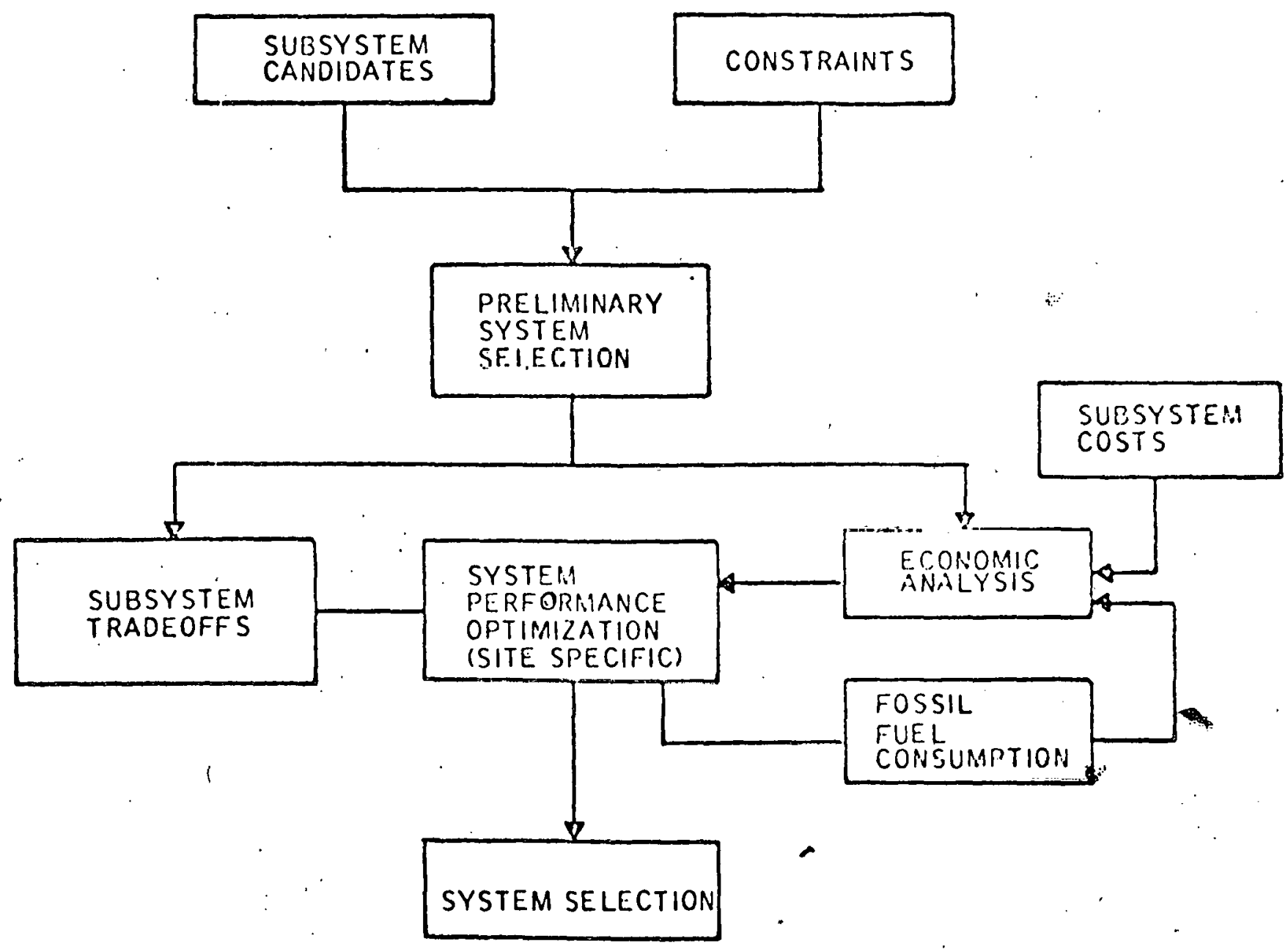

Figure 3-1. System Selection Flow Chart 
The solar system performance is determined using Iloneywell's Solar Systems Simulation Program. The economic analysis technique is used in conjunction with the simulation program to optimize the selected systems for the designated area and application.

\subsection{Subsystem Candidates}

Subsystem candidates include all those solar heating system components that could be used to design heating systems. Candidate subsystem components identified are listed in Table 3-1. The table includes all those subsystem components that appear to be feasible candidates. Subsystem candidates are categorized by collectors, storage, auxiliary subsystems, working fluid and supplementary elements.

\subsection{Constraints and Design Criteria}

Constraints or evaluation criteria have been identified for purposes of performing preliminary and detailed trade-offs of subsystem components. These include the following:

- Modularity -- subsystems components that are of standard design and size that can be put together to achieve the desired capability. An example that meets this constraint is the flat plate collector panel, a component of standard size that can be combined to create any desired collector area.

- Scalability -- a subsystem component of standard design that can provide a progressive increase in capability by changing some of the components of that subsystem. An example of this type of subsystem component is the standard home furnace, the output capability of which can be increased by scaling burners and blower motor. 
Table 3-1

Subsystem Component Candidates

Subsystem

Collectors

Thermal Storage Media

Auxiliary Subsystems

Working Fluids

Supplementary Elements

\section{Component}

- Liquid Mat plate

- Concentrator:

- Tracking - two planes

- Partial tracking - tracking in one plane

- Nontracking - fixed

- Air hcater

- Water

- Ethylene glycol/water solution

- Rock pile

- Heat-of-fusion materials

- Fossil fueled forced air furnace

- Fossil fueled hydronic boiler

- Heating only heat pumps

- Air

- Water/ethylene glycol

- Water

- Oil

- Heat transfer fluids

- Fans

- Ducts

- Controls

- Piping

- Pumps 
- Architectural Aspects -- includes interface of solar heating systems on a building (especially collectors), impact on construction and aesthetic qualities

- Fuel Type Availability -- assurance that local utilities will provide the type and amounts of fuel required

- Economic Aspects -- costs of procurement, installation, maintenance and operation

- Development Risks -- availability of components within required time frame - subsystem design maturity:

- Maintainability -- skill, knowledge. and training required to maintain system.

- Reliability -- confidence in assuring continued system operation over life cycle

- Safety -- safety of operation and use of system

- Control Philosophy -- control of solar heating system to use needed energy di rectly from collector or storage. Store excess energy and use auxiliary energy when required.

\section{4 Preliminary Subsystem Component Selection}

The preliminary subsystem selection is designed to narrow the list of subsystem candidates for final consideration. By using the constraints identified, advantages and disadvantages of each subsystem component are examined with respect to these constraints. Relative strengths and weaknesses are identified and components can be ranked with respect to each other. 
It becomes evident that collectors, auxiliary heating, and storage subsystems are the three most critical elements of heating system designs. Other subsystems, such as space heat, domestic hot water and controls, are easily defined after the selection of these three primary subsystems. There are three types of collectors which have been considered, liquid cooled flat plate, concentrators and air heaters. The types of auxiliary heating subsystems are a fossil fueled or electric forced air furnace, a fossil fueled or electric hydronic boilder and the third is an electric heat pump. Storage choices are rock, water and salt. The matix shown in Figure 3-2 defines various system possibilities.

Figure 3-2

Possible System Combinations
Collector
Storage
Furnace

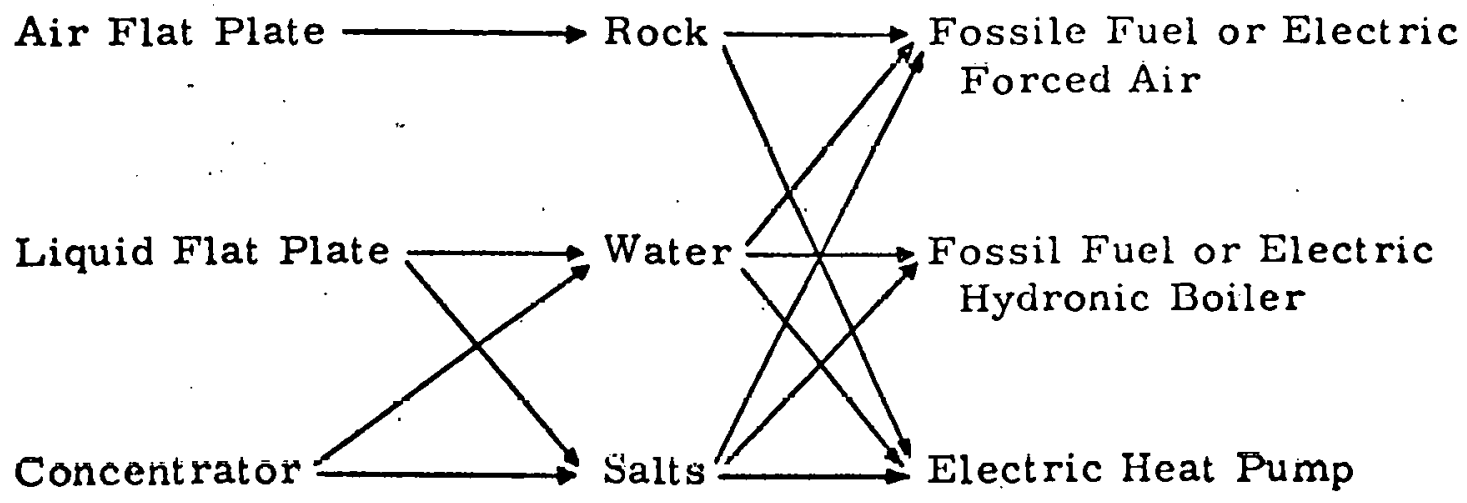

Some system combinations were eliminated because of the general mismatch between subsystems such as air collectors and water storage. Some combinations may be possible but development risks, at present, outweigh advantages (i.e., air collectors with salt storage). Other general tradeoffs are listed below for each of the three major subsystem types. 
Collector type --

- Air and liquid flat plate collectors are generally simpler and offer less development risk than concent rator collectors.

- Liquid flat plates are slightly better than air collectors based on performance and development risk criteria.

Storage type --

- Phase change storage systems require a significant development risk.

- Liquid storage is more efficient than rock storage and is readily available from storage tank manufacturers.

Auxiliary subsystem type --

- Fossil fuel or electric forced air furnaces are the most common heating source and are easily adapted auxiliary energy subsystems for solar system applications.

- Heat pumps for solar application require development and some initial system cost increases.

- Due to the potential shortage of gas and oil in various regions, heat pumps may be necessary as auxiliary heating units.

The system providing the best match of subsystem components with the smallest development risk for space heating applications is a liquid cooled flat plate collector with sensible heat water storage and a gas fired forced air furnace as the auxiliary heating source. In the event that gas is not available, heat pumps or electric furnaces may be considered in conjunction with the solar heating systcm.

Numerous other workable systems exist for heating applications. Further studies and trade-offs could yield insights into the use of concent rators or air heaters along with the associated storage and auxiliary energy, subsystems mentioned above for space heating applications. 


\subsection{Baseline Systems}

\subsection{Introduction}

The proposed solar assisted heating systems are two fluid loop solar collector systems interfacing with conventional fossil fuel fired furnaces. These proposed system designs may be easily sized to fit a wide spectrum of applications. First, the collectors are modular and can be combined in arrays to satisfy site-specific collector configurations. Second, the auxiliary subsystems are selected from a broad product line of fossil fuel-fired warm air furnaces, allowing many choices to fit site-specific requirements. Finally, the storage, hot water, transport and control subsystems are commercially produced items in a broad range of sizes. This subsystem modularity allows variations in system design to accommodate the variable performance requirements that are expected nationwide.

The proposed solar systems are designed to maximize the amount of solar energy collected for use and storage. This is accomplished by:

- A control system that minimizes collector inlet temperatures (maximizes energy into the building)

- Optimum transfer rate heat exchangers

- Direct collector to space heating by by-passing storage.

- Using high-performance flat plate collectors 
- Storage which can be operated in parallel and independently from collectór loop

System reliability and maintainability is assured through design features which include the following:

- A slosed collector loop for over temperature protection via a purge coil

- A control system employing simple logic

- A minimum of components in the system

- Manifolding external to the collector modules

Maintenance of space temperature, hence occupant comfort, is assured through the use of the following components and design techniques:

- A two-stage thermostat with a min imum differential for solar operation

- Conventional furnace control of air temperature to the spare

The systems have been designed to minimize contamination of the potable water supply by the use of:

- A two-fluid loop system that isolates the collector heat transfer fluid

- A system in which domestic water pressure is higher than system pressures 
4.2 Single Family Residential Heating System Description

The proposed system for a single family residential heating system is a two-fluid-loop, solar assisted, hydronic-to-warm-air system with solar assisted domestic water heating. The system is composed of the following major components:

- Liquid cooled Mat plate collectors

- A water storage tank

- A passive solar fired domestic water preheater

- A gas fired hot water heater

- A gas fired warm air furnace with hot water coil unit

- A tube-and-shell heat exchanger, three pumps and associated pipes and valving

- A control system

- An air-cooled heat purge unit

A schematic of the system configuration is shown in Drawing SK140094. The solar collectors supply heat to the furnace through the hot water coil in the furnace return air section and to the storage both through the tubeand-shell heat exchanger in the collector loop. Heat is withdrawn from storage to the hot water coil in the furnace when energy from the collectors is not available. Domestic hot water heating is supplied from storage by the passive heating system in the storage tank. Auxiliary heat is supplied by the gas fired section of the warm air furnace and domestic water heating is tempered by the gas fired hot water heater. The system operates on a priority load basis, providing energy to the space heating load whenever the solar collectors have adequate energy available and the load demands heat. If the space heating load is not demanding energy, the solar collectors can provide energy to the storage tank and hence to the domestic hot water preheater. The storage tank can supply energy to the space heating load and to the domestic hot water system if the solar 
collectors do not have adequate energy available. In the case of high solar availability and no energy demand from space heating, domestic hot water, or storage load, a purge coil has been provided to dissipate the excess energy.

4.3 Multifamily Residential Heating System Description

The proposed system for a multifamily residential dwelling is a two-fluidloop primary-secondary circulation system for hydronic-to-warm-air heating with solar assisted domestic water heating. The system will provide heat for 12 apartments through individual gas fired furnaces with hot water coils in the return air system, and domestic water to the apartments through a central domestic water heating system. The system has the following major components:

- Liquid cooled flat plate collectors

- A water storage tank for sensible heat storage

- An active solar fired domestic water preheater

- Three gas fired water heaters

- Twelve gas fired warm air furnaces with hot water coil unit

- A tube-and-shell heat exchanger, two main circulating pumps, 12 secondary pumps, 1 hot water pump and associated pipes and valving.

- Control system

- An air-cooled heat purge unit

A schematic of the system configuration is shown in Drawing SK 140095. The solar collectors supply heat to the apartment units through the hot water coils in each furnace. The gas fired domestic water heaters are connected in parallel to provide the capacity requirements of the RFP. 
The system is similar to the single family residence heating system only in that both have pressurized collector loops isolated from the nonpressurized water loop through a tube-and-shell heat exchanger. In addition, the multifamily residence system has a series of secondary pumping loops to each multifamily unit. These secondary loops provide for independent supply of solar heated water without the expenditure of excessive pumping power requirements. The control system is an expanded version of the single family system.

\subsection{Commercial Applications Heating System Description}

The proposed system for commercial building heating is a two-nuid-loop. primary-secondary circulation system for hydronic-to-warm-air heating with solar assisted domestic water heating. The system will provide space heating through gas fired rooftop heating furnaces, and domestic water heating through a solar heated preheater and gas fired water heater. The system is composed of the following major components:

- Liquid cooled flat plate collectors

- A water storage tank for sensible heat storage

- An active solar fired domestic water preheater

- A gas fired water heater

- Gas fired, rooftop mounted furnaces with hot water coil units

- A tube-and-shell heat exchanger, two main pumps and four secondary pumps and associated pipes and valves

- A control system

- An air cooled heat purge unit

A schematic of the proposed system configuration is shown in Drawing SK 140096. The system is similar in operation to the residential and multifamily systems and will provide for four zones of heating with operation of each zone similar to the residential system or to the multifamily heating system. 


\subsection{System Controls}

Each of the proposed systems is controlled to assure maximum utilization of collected energy and excellent control of space temperature: The single family control sensor locations are shown in Drawing SK 140103 while a control ladder diagram and sequence of operation are shown in Drawing SK 140104.

Similar drawings are shown for the multifamily system in Drawing SK 140101 and SK 140102 while the commercial system controls are shown in SK 140106 and SK 140107. 


\subsection{Trade Studies}

\subsection{Methodology}

A methodology for a comparison of solar-assisted heating system concepts has been established. The methodology or approach allows a complete examination of the solar system and subsystem candidates. In order to assure that the solar systems development results in products that meet the requirements, the studies included variations in key parameters that influence solar heating systems casts and performance. A systems simulation program was used to study the solar sys tems cost and/or performance variation as a result of $a$ variation in the key parameters.

The system tradeoff methodology is shown schematically in Figure $5.1-1$.

\subsection{Criteria}

The criteria for selection of a solar system configuration will be the following.

- Minimum annual cost per million Btu solar energy provided

- System safety

- Development risk

- Architectural considerations 


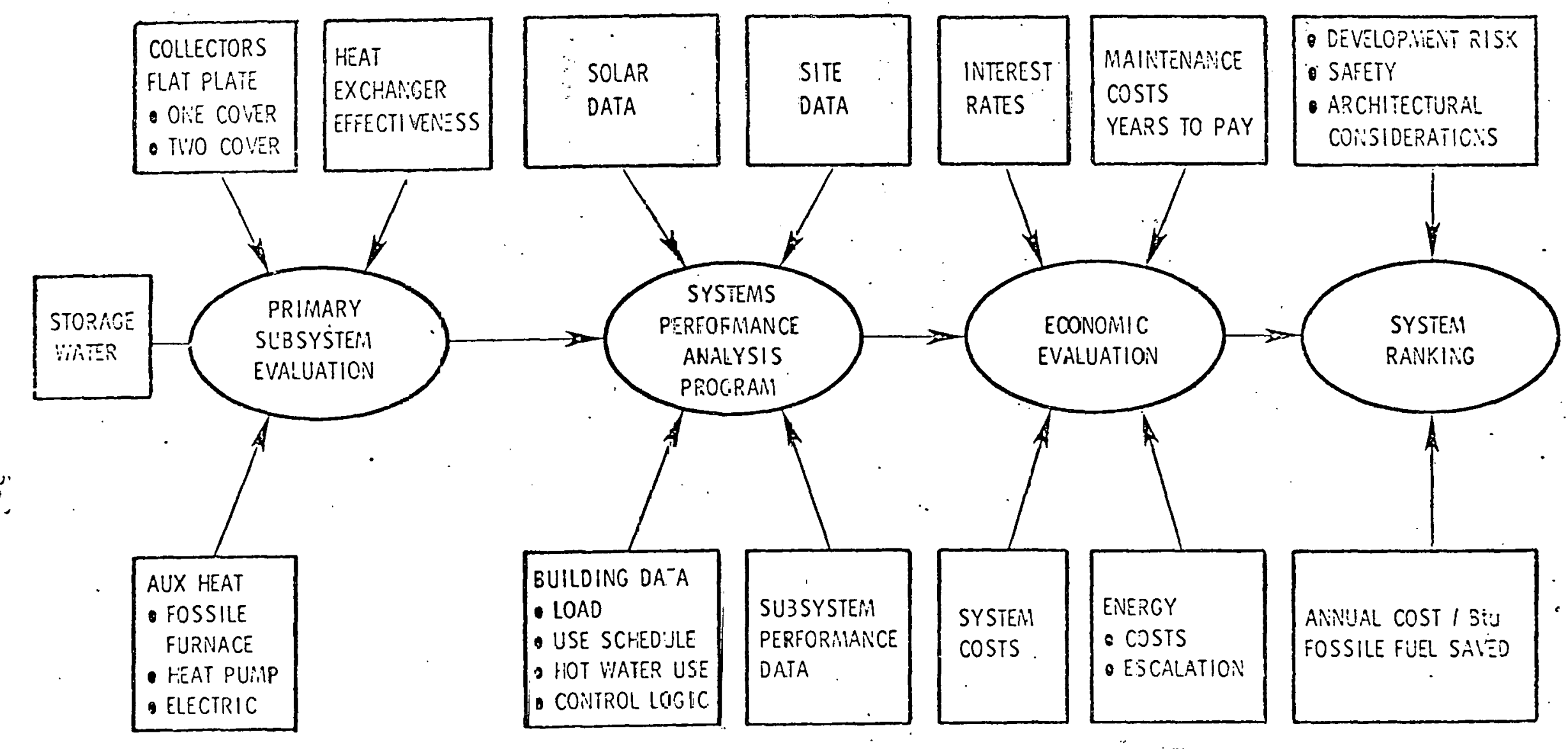

SYSTEN: IRADEOFF FLOW CHART

Figure 5.1-1 
Table 5.3.1-1

Average Monthly Degree Days for Minneapolis

January

1631

February

1380

March

1166

April

621

May

288

June

81

July

22

August

31

September

189

October

505

November

1014

December

1454

Total

8382 
5.3 Parameters and Assumptions

The prediction of the performance and economics of a solar heating system is based on a simulation analysis using observed weather and solar data generated from cloud cover. The actual system is simulated by a digital computer code on an hour-by-hour basis.

Since specific government selected sites were not available prior to the heating systems preliminary design review, Minneapolis was selected as a site for the systems. A description of the basic parameters and assumptions used in the trade-off studies follows.

5.3.1 Site

Minneapolis was selected as the site for the trade-off studies for heating systems. Minneapolis is located at $44.7 \mathrm{deg} r e e s$ north latitude and 93 degrees longitude.

The mean daily total solar radiation for Minneapolis is approximately 345 1 Langleys. This value varies from about 125 Langleys in December to about 560 Langleys in June. The contoured charts of solar radiation are shown in Figures 5.3.1-1 to 5.3.1-3. These data were taken from the Climatic Atlas of the United States published in 1968 by National Climatic Center, Asheville, North Carolina. The national charts showing mean percentage of sunshine and total hours of sunshine are presented in Figures 5.3.1-4 and 5.3.1-5. An interpolation of these charts shows that Minneapolis has approximately 2550 hours of sunshine annually, or approximately 55 percent of the possible sunshine.

The average annual degree days for Minneapolis is 8382. (Reference ASHRAE Systems Handbook, Chapter 43.4). The average heating season temperature, Octoiver to April, is approximately $28 \mathrm{~F}$. The monthly average degree days in shown in Table 5.3.1-1. 
MEAN DARY SOLAR RAD:ATON, MONTHEY AND ANNJALL

MHT Of THE NATONA: ATH US DEPAKTMENT OF COMMERCE

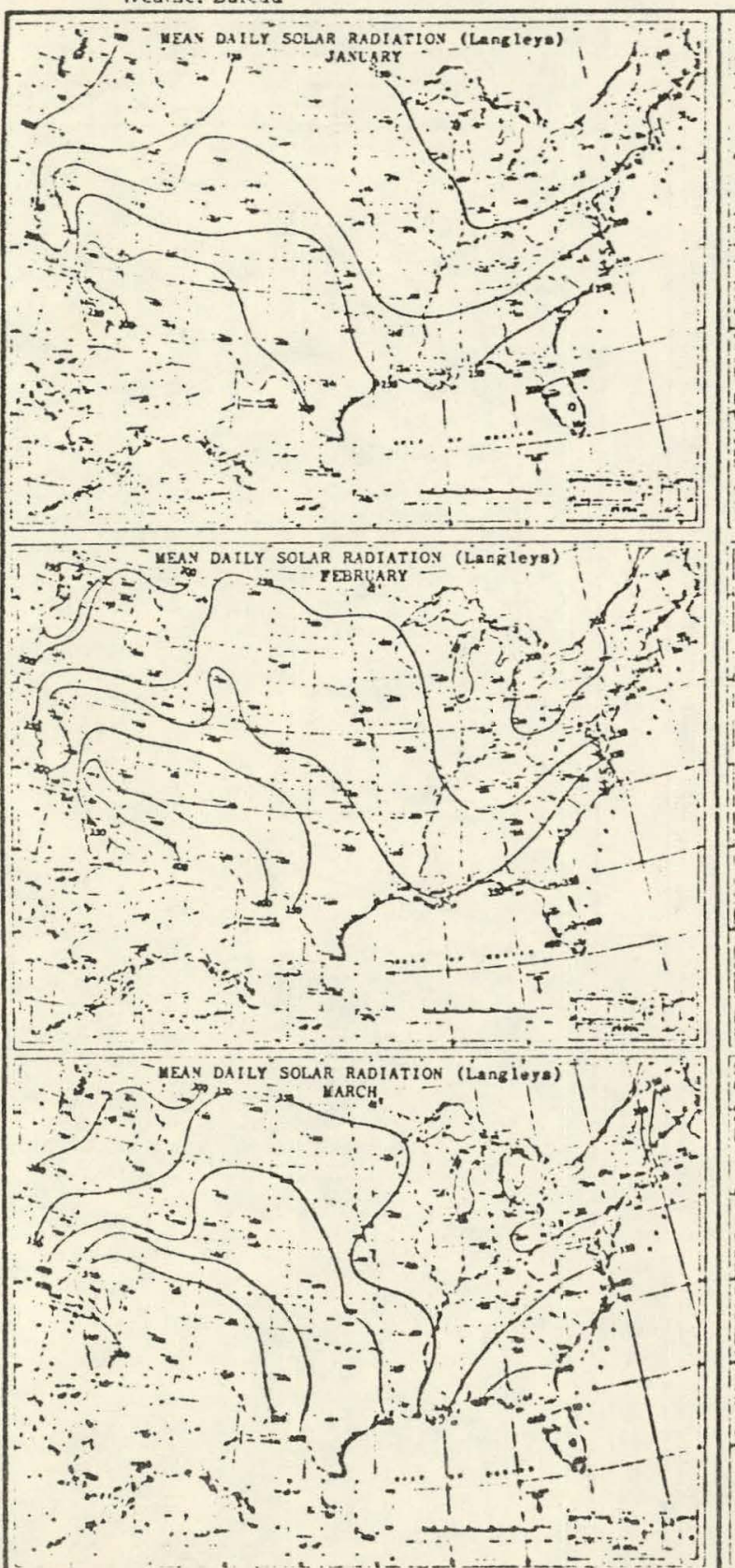

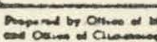

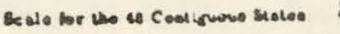

\section{(Y) WEAN OAILY SOLAT RADIATION (LANK LEYB)}

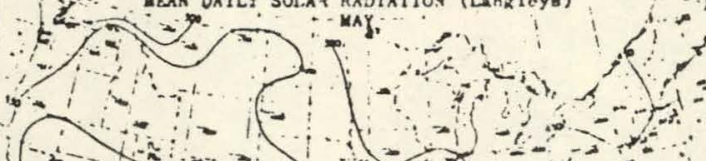

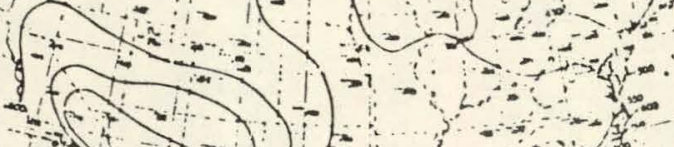
$\because-1=0$

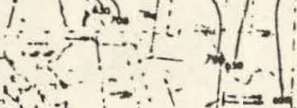

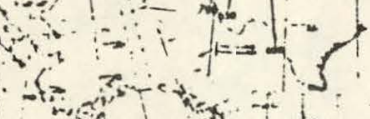

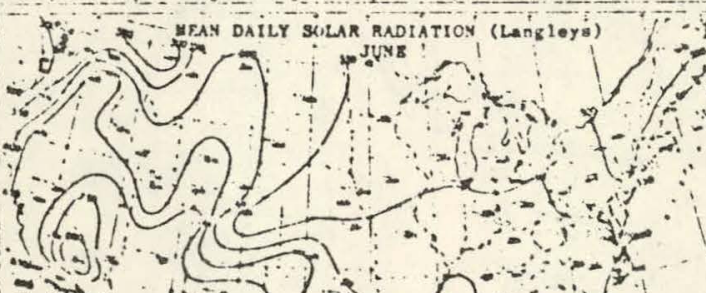

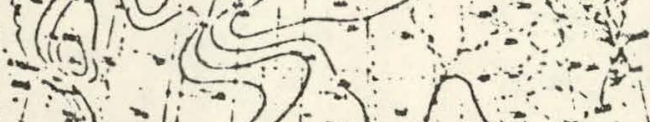

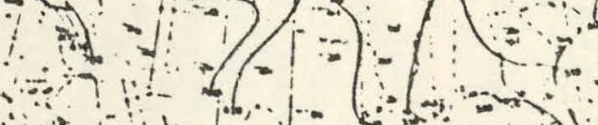

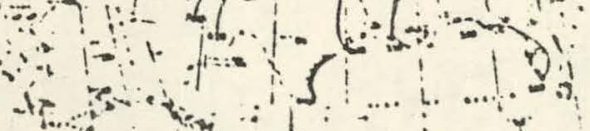

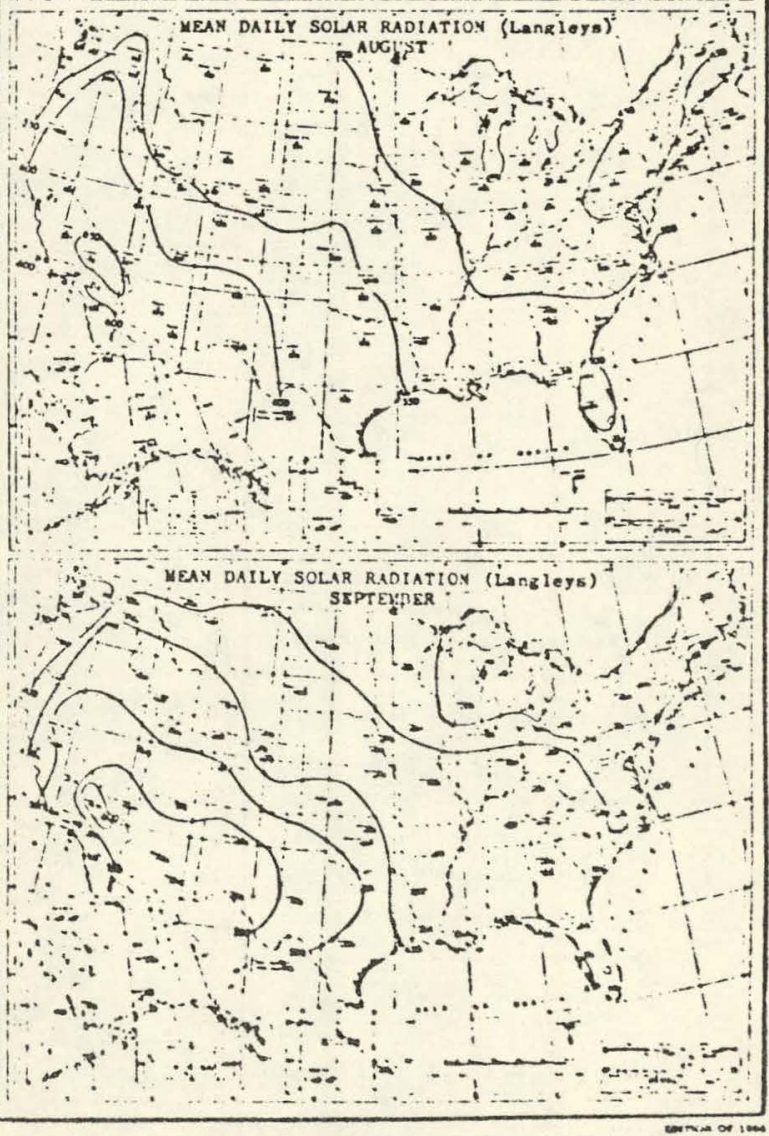

DOAN DAIY SOLAR ROLATOK, WONTRIY AND NYNUN

I1gure $3.3 .1-1$ 
MEN DALY SOLAR RADUTOR, MONTHYY AND ANWUR-CONHUEd



Elgure 5.3.1-2 


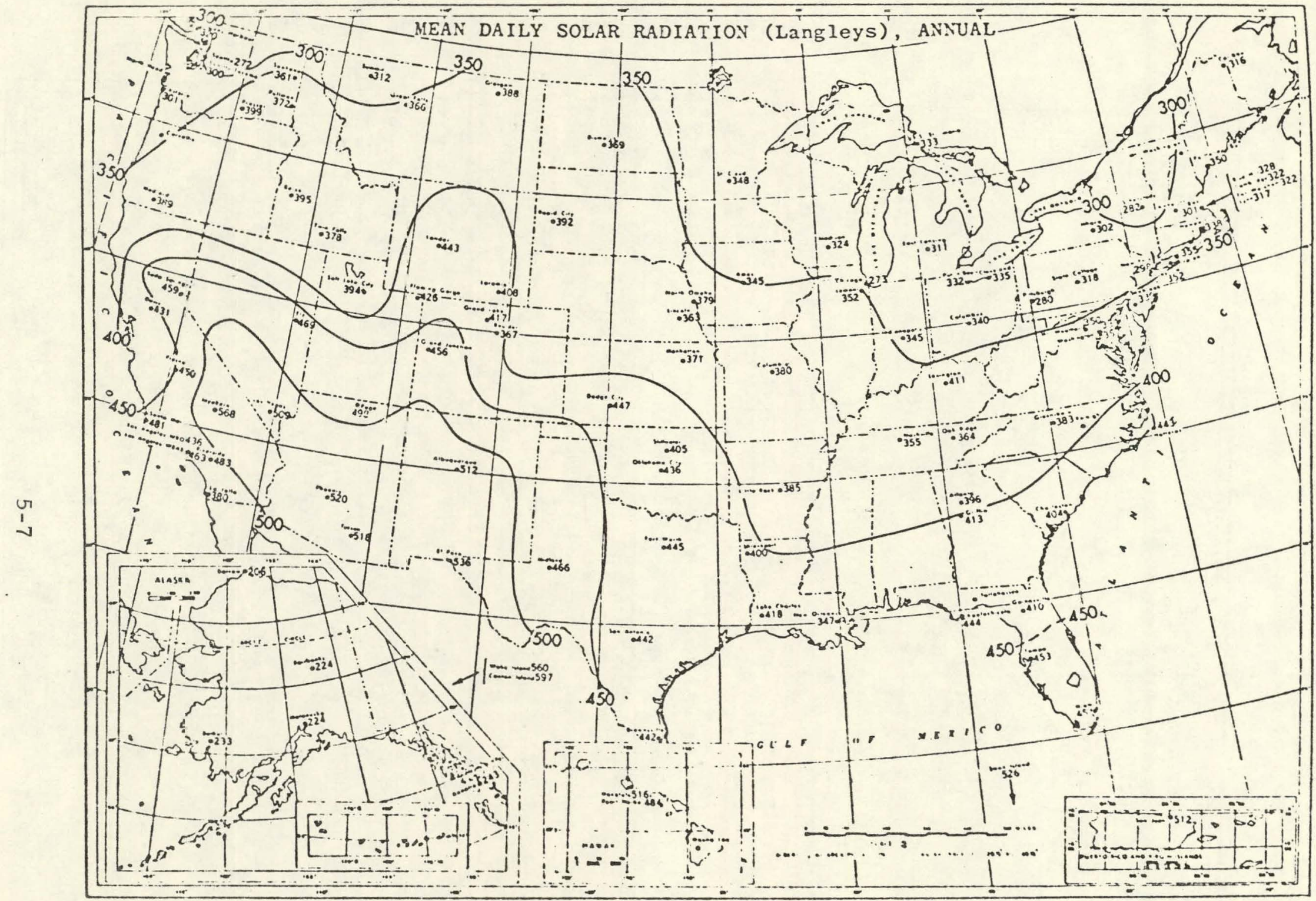

Figure 5.3.1-3 Mean Daily Total Radiation, Annual 

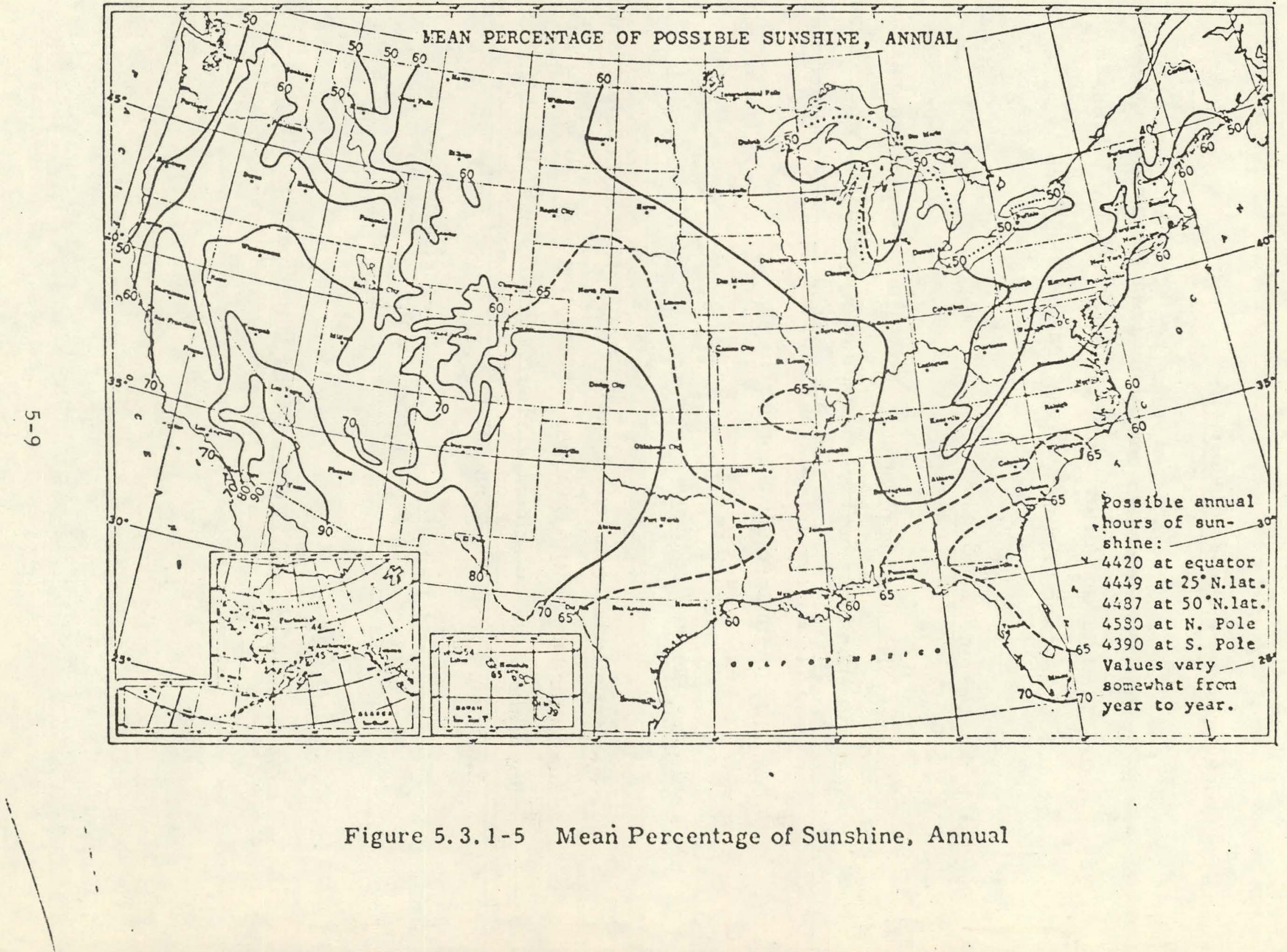

Figure 5.3.1-5 Mean Percentage of Sunshine, Annual 


\section{3 .2 Heating System Design Conditions}

The heating system design conditions are based on the requirements outlined in Interim Performance Criteria for Solar Heating and Combined Heating and Cooling systems and Dwellings (IPC).

\subsubsection{Inside Design Conditions}

Winter - - The heating plant capacity will be based on the maximum instantaneous block heat loss at outside winter design when calculated for an inside temperature of $70^{\circ} \mathrm{F}$ dry bulb, and the selected relative humidity for the project if applicable.

\subsubsection{Outside Design Conditions}

The design will be based on weather data given in the latest issue of the applicable ASHRAE Guide. The heating load will be designed on the basis of the coincident wind velocity and the $97 \mathrm{l} / 2$ percent column. These conditions for Minneapolis are:

Winter: $\quad-10 \mathrm{~F}(971 / 2 \%$ column $)$

For reference, the medium of annual extremes for Minneapolis is - $19 \mathrm{~F}$. 


\subsubsection{Building Heating Loads}

The building heating loads are based on the ASHRAE standard 90-75.

- Since no specific buildings or sites have been identified, typical sizes have been used for calculating the energy demands for heating a single family and multifamily residence and a small commercial building.

\subsubsection{Single Family Residence}

The single family residence was assumed to be a single story, 1500 $\mathrm{ft}^{2}$, rectangular building $(25 \times 60 \mathrm{ft})$, facing south. The " $\mathrm{U}$ " valves for the walls and ceiling were taken from ASHRAE standard 90-75. For Minneapolis with 8382 degree days, Figure 5.3.6-1 shows for a type " $\mathrm{A}$ " building, the " $\mathrm{U}$ " valve is $0.185 \mathrm{Btu} / \mathrm{hr}$ - $\mathrm{ft}^{2} \cdot \mathrm{F}$. (Reference ASHRAE 90-75 paragraph 4.3.2.2).

The overall thermal transmission conductance is the combination of heat flow through the walls and ceiling.

$$
\begin{aligned}
\mathrm{U}_{\text {WALL }} & =.185 \\
\mathrm{U}_{\text {CEILING }} & =.04 \\
\mathrm{UA}_{\text {TOT }} & =.185(170)(8)+1500(.04) \\
& =311.6 \mathrm{Btu} / \mathrm{hr}^{\circ} \mathrm{F}
\end{aligned}
$$

This value includes the transmission through any doors and windows included in the outside walls. 
The infiltration through cracks and seams was assumed to be .75 air changes per hour. For a $1500 \mathrm{ft}^{2}$ house with an $8 \mathrm{ft}$. ceiling this is $9000 \mathrm{ft}^{3} / \mathrm{hr}$ of outside air which has to be heated.

$$
\text { For infiltration } \begin{aligned}
\mathrm{UA}=\dot{\mathrm{m}} \mathrm{C}_{\mathrm{p}} & =9000(.24)(.075) \\
& =162 \mathrm{Btu} / \mathrm{hr} \mathrm{F}
\end{aligned}
$$

The total "UA" including transmission and infiltration is:

$$
\mathrm{UA}_{\text {TOTAL }}=162+311=473 \mathrm{Btu} / \mathrm{hr} \mathrm{F}
$$

The design load for the single family residence is:

$$
\begin{aligned}
& \mathrm{Q}=\mathrm{UA}\left(\mathrm{T}_{\text {ROOM }}{ }^{-\mathrm{T}_{\text {AMBIENT }}}{ }^{\prime}\right. \\
& \mathrm{Q}=473(70-(-10))=37840 \mathrm{Btu} / \mathrm{hr}
\end{aligned}
$$

Our internal load was assumed to account for people and lighls. This load schedule was:

$$
\begin{aligned}
& 8 \text { a.m. }-8 \text { p.m. }--2550 \mathrm{Btu} / \mathrm{hr} \\
& 8 \text { p.m. }-8 \text { a.m. }--1350 \mathrm{Btu} / \mathrm{hr}
\end{aligned}
$$


TYPE A BUILDINGS SHALL INCLUDE:

A 1 DETACHED ONE AND TWO FAMILY DWELLINGS

A 2 ALLOTHER RESIDENTIAL BUILDINGS, THREE STORIES OR LESS, INCLUDING BUT NOT LINIITED TO:

MULTI.FAMILY DWELLINGS HOTELS AND MOTELS

ANNUAL CELSIUS HEATING DEGREE DAYS (18 C BASE) (IN THOUSANDS)

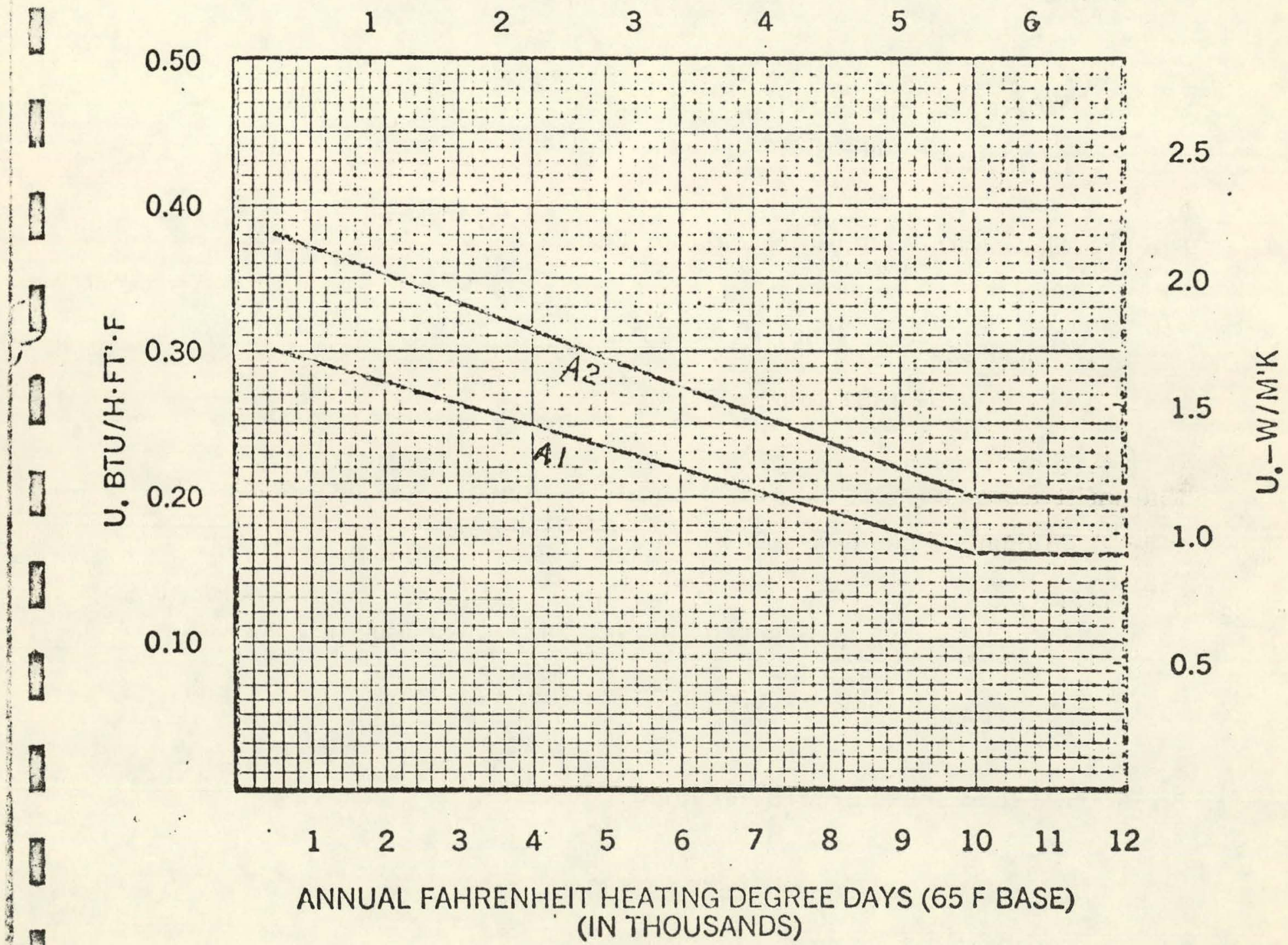

Figure 5.3.6-1 


\subsubsection{Multifamily Residence}

The multifamily residence was assumed to be a 12 unit, two story, $15000 \mathrm{ft}^{2}$, rectangular building $(70 \times 105 \mathrm{ft})$, facing south. Each unit would contain $1250 \mathrm{ft}^{2}$. The " $\mathrm{U}$ " valves for the walls and ceiling were taken from Figure 5.3.6-1 and paragraphs 4.3.2.2 of ASHRAE 90-75.

$$
\begin{aligned}
& U_{\text {WALL }}=.23 \\
& U_{\text {CEILING }}=.04
\end{aligned}
$$

The overall transmission is calculated as:

$$
\begin{aligned}
\mathrm{UA}_{\text {TOTAL }} & =.23(350)+.04(7350) \\
& =1582 \mathrm{Btu} / \mathrm{hr} \mathrm{F}
\end{aligned}
$$

The infiltration, as with the single family residence, was assumed to be 0.75 changes per hours, or $90000 \mathrm{ft}^{3} / \mathrm{hr}$.

$$
\begin{aligned}
& \text { UA } \\
& \text { INFILTRATION } \\
& \text { UA }_{\text {TOTAL }}=160000(.075)(.29)=1620 \mathrm{Btu} / \mathrm{hr} \mathrm{F}
\end{aligned}
$$

An internal load schedule was assumed.

$$
\begin{aligned}
& 8 \text { a.m. }-8 \text { p.m. } \\
& 8 \text { p.m. }-8 \text { a.m. }
\end{aligned}
$$

These internal loads are the same as was included in RFP-404. 
5.3.8 Commercial Building

The commercial building was a $32500 \mathrm{ft}^{2}$ single story, rectangular $\left(100-325 \mathrm{ft}^{2}\right)$ building. This is identical to the building size specified in RFP-404. The building loads are different than RFP-404 and were calculated from ASHRAE 90-75.

The " $U$ " valve for the commercial building was taken from figure 5.3.8-1. For a building under three stories and 8382 degree days in Minneapolis, the " $\mathrm{U}$ " valve is $0.23 \mathrm{Btu} / \mathrm{Hr}$. $\mathrm{ft}^{2} \mathrm{~F}$. The ceiling " $\mathrm{U}$ " valve is $0.06 \mathrm{BTU} / \mathrm{Hr}, \mathrm{ft}^{2} \mathrm{~F}$ as shown in figure 5.3.8-2 for 8382 degree days. The combined transmission conductance is calculated for a 10 foot high wall as:

$$
\begin{aligned}
\mathrm{UA}_{\text {Transmission }} & =.23(850)(10)+.06(32500) \\
& =3905 \mathrm{Btu} / \mathrm{Hr} . \mathrm{F}
\end{aligned}
$$

The infiltration load was assumed to be the same as specified in RFP -404 as $225 \mathrm{cfm}$ or UA Infiltration $=243 \mathrm{Btu} / \mathrm{Hr} . \mathrm{F}$ The ventilation schedule was also taken from RFP-404.

$$
\begin{array}{ll}
270000 \mathrm{ft}^{3} / \mathrm{Hr} .(\mathrm{UA}=4860) & 8 \mathrm{AM}-7 \mathrm{PM} \\
0 & 7 \mathrm{PM}-8 \mathrm{AM}
\end{array}
$$

The internal load schedule for people and lights was:

$$
\begin{aligned}
& \text { Lights: } 213180 \mathrm{Btu} / \mathrm{Hr} \text {. } 8 \text { AIM - } 7 \text { PIM } \\
& 106590 " \quad 7 \mathrm{PM}-8 \mathrm{AM} \\
& \text { People: } 60000 " \quad \text { " } 8 \text { AM }-7 \text { PM } \\
& 0 \quad " \quad 7 \mathrm{PM}-8 \mathrm{AM}
\end{aligned}
$$

The total "UA" coefficient is:

$$
\begin{aligned}
\mathrm{UA}_{\text {Total }} & =\mathrm{UA}_{\text {Trans }}+\mathrm{UA}_{\text {Vent }}+\mathrm{UA}_{\text {In fil }} \\
& =3905+243+4860 \\
& =9008 \mathrm{Btu} / \mathrm{Hr} . \mathrm{F} 8 \mathrm{AM}-7 \mathrm{PM} \\
& =4148 \mathrm{Btu} / \mathrm{Hr}, \mathrm{F} 7 \mathrm{PM}-8 \mathrm{AM}
\end{aligned}
$$


UO WALLS-HEATNGG-TYPE- "B" BULLDMGG FOR ALL BUILDINGS NOT COVERED BY PARA. 4.3

ANNUAL CELSIUS HEATING DEGREE DAYS (13 C BASE) (IN THOUSANDS)

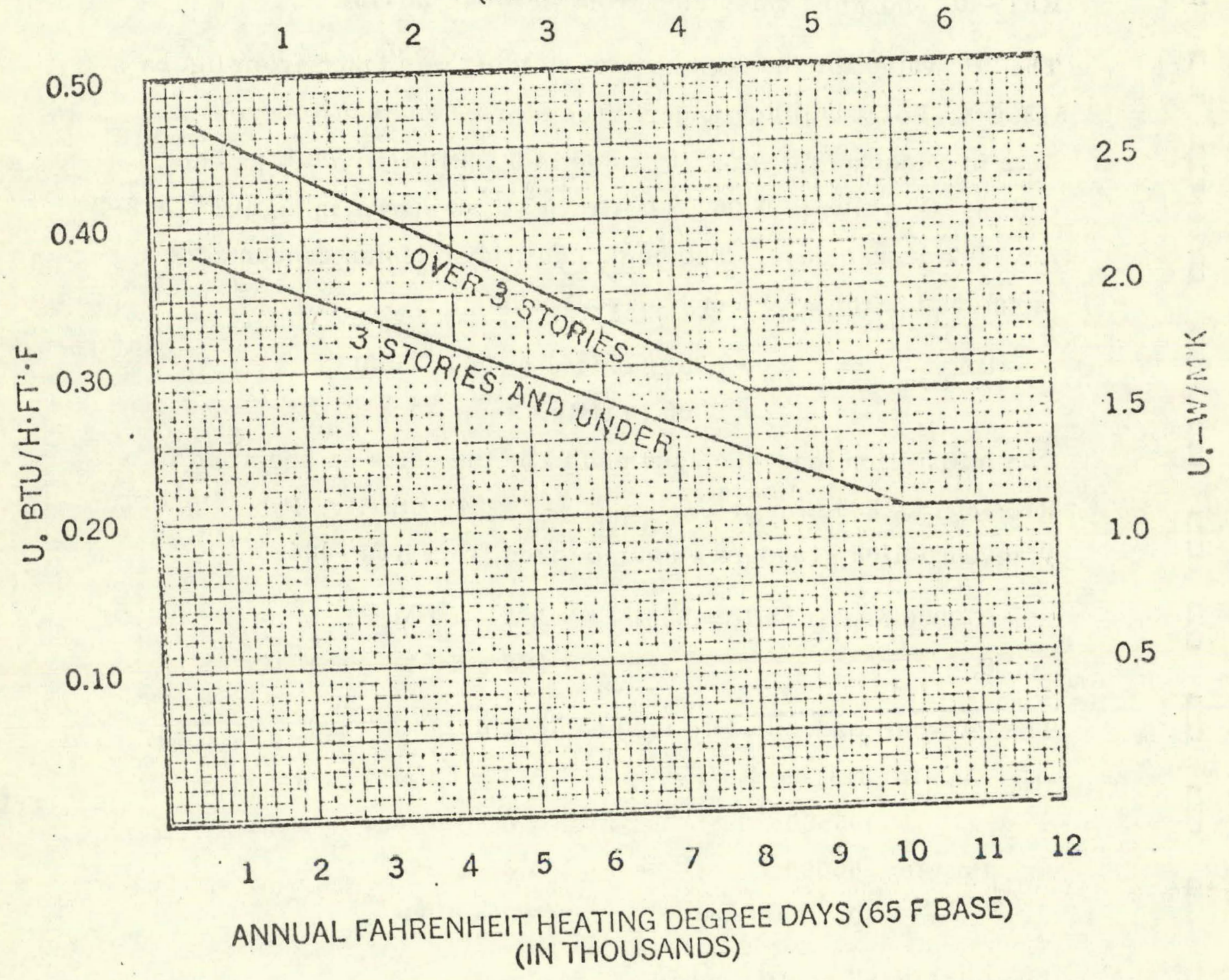

Figure 5.3.8-1 


$$
\begin{gathered}
\text { Uo-ROOFS AND CEILLNGS } \\
\text { TYPE"B" BUILDINGS }
\end{gathered}
$$

FOR ALL BUILDINGS NOT COVERED BY PARA. 4.3 ANNUAL CELSIUS HEATING DEGREE DAYS (18 C BASE)

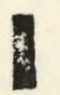

1

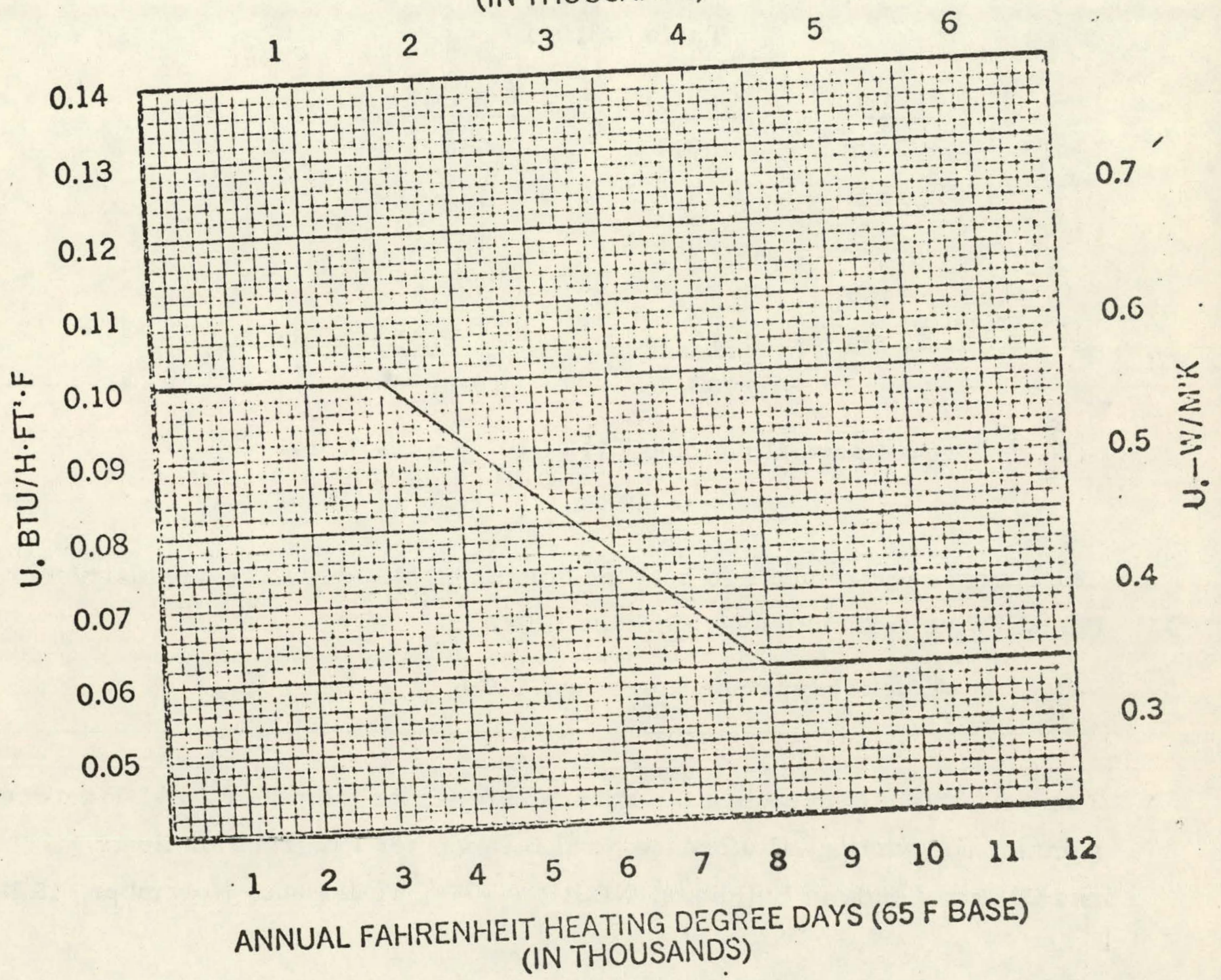

Figure 5.3.8-2 
5.3.9 Domestic Hot Water

The domestic hot water schedule for the three types of building is shown in Table 5.3.9-1 and graphically in Figure 5.3.9-1 to 5.3.9-3.

Table 5.3.9-1

$\begin{array}{rrrr}\frac{\text { Time }}{7 \mathrm{am}} & \text { Gal (SF) } & & \text { Gal (MF) } \\ 10 \mathrm{am} & 90.4 & 630 \\ 1 \mathrm{pm} & 9.8 & 122.4 \\ 4 \mathrm{pm} & 9.8 & 122.4 \\ 10 \mathrm{pm} & \frac{11.1}{100.7} & \frac{138.4}{1258}\end{array}$

Commercial building: $\begin{array}{ccc}115 \mathrm{GPH} & 8 \mathrm{am}-7 \mathrm{pm} \\ 0 \mathrm{GPH} & 7 \mathrm{pm}-8 \mathrm{am}\end{array}$

The energy requirements to heat the domestic hot water were calculated with the following assumptions (reference IPC).

$$
\begin{aligned}
& \text { delivery temperature }=140 \mathrm{~F} \\
& \text { supply lemperaluse }
\end{aligned}
$$

The well water temperature for Minneapolis varies from $39 \mathrm{~F}$ to $57 \mathrm{~F}$ between summer and winter. (Reference NBSLD Computer Program for Heating and Cooling Loads in Buildings, NBS1R 74-574, T. Kusuda, November, 1974). 
Figure 5.3.9-1

ASSUMED USE PROFILE FOR DONIESTIC HOT WATER SINGLE FAMILY RESIDENCE

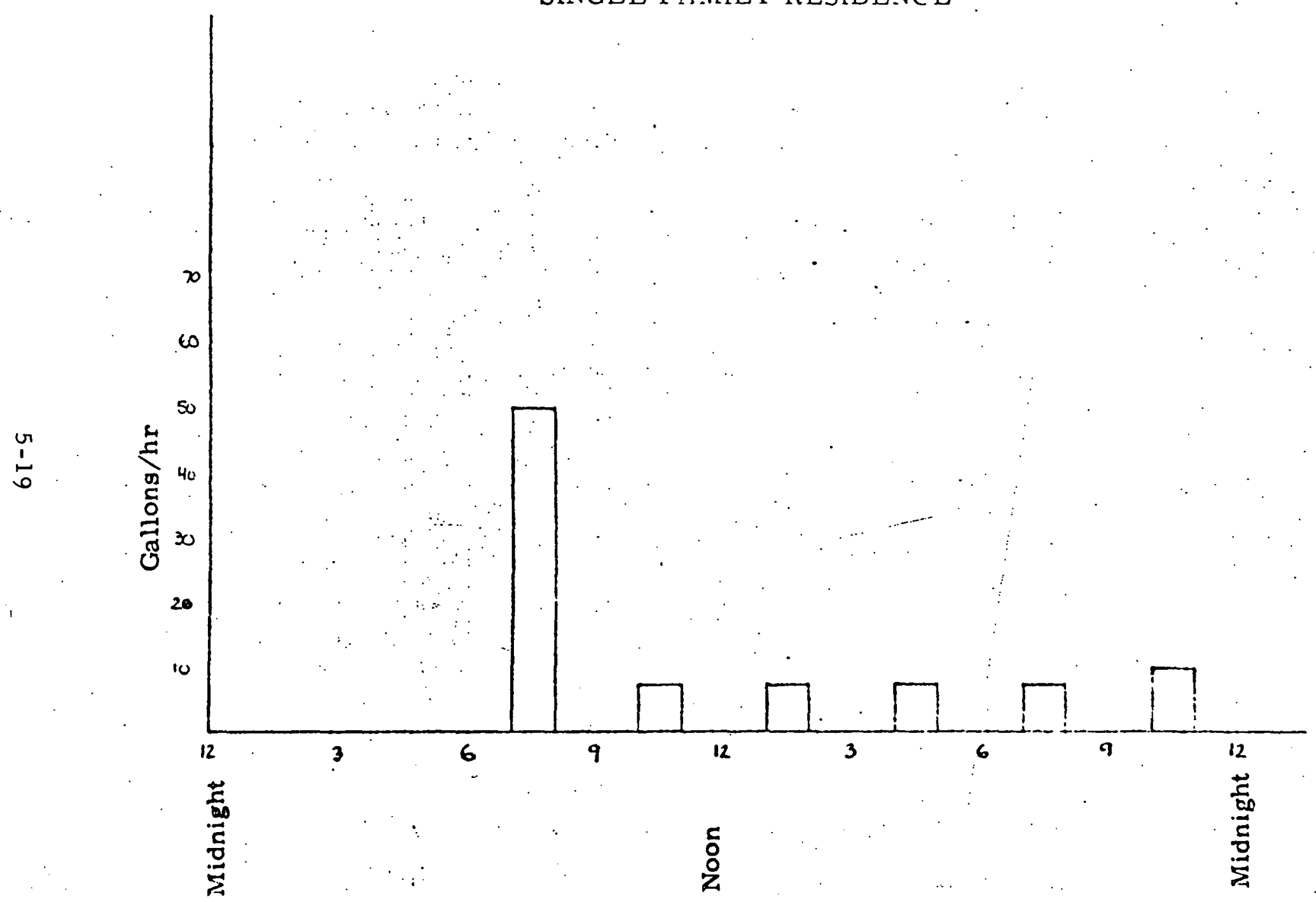

Time of Day 
Figure 5.3.9-2

ASSUMIED USE PFOFILE FOR DOMIESTIC HOT WATER

MULTIFAMILY RESIDENCE

$\stackrel{T}{i}$

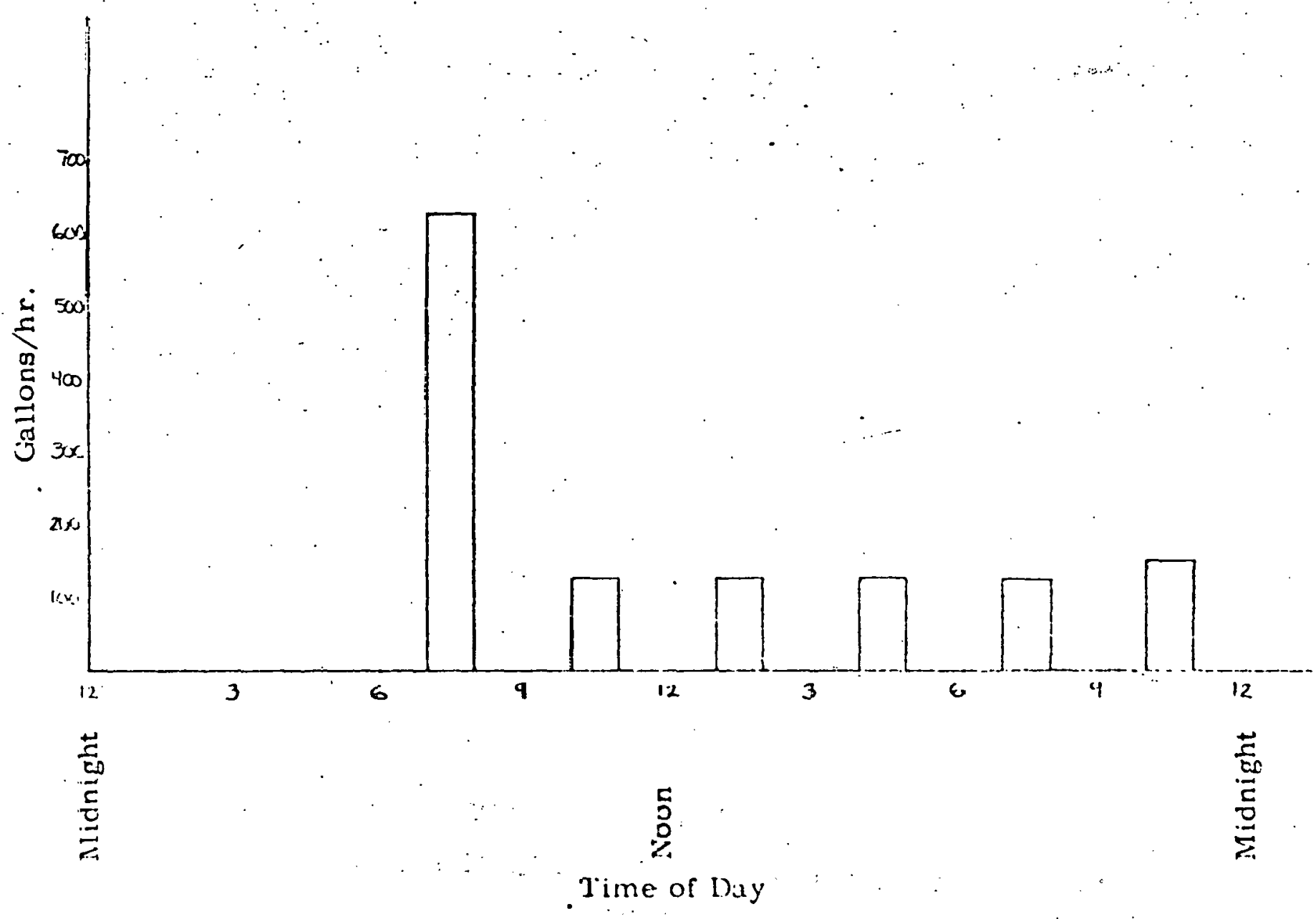




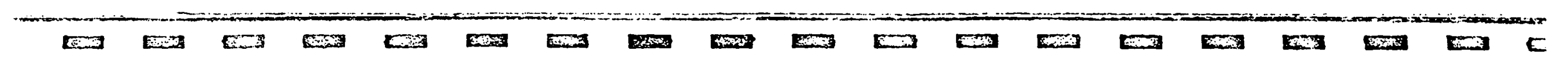

Figure 5.3.9-3

ASSUMED USE FROFILE FOR DCMESTIC HOT WATER

COMMERCIAL BUILDING

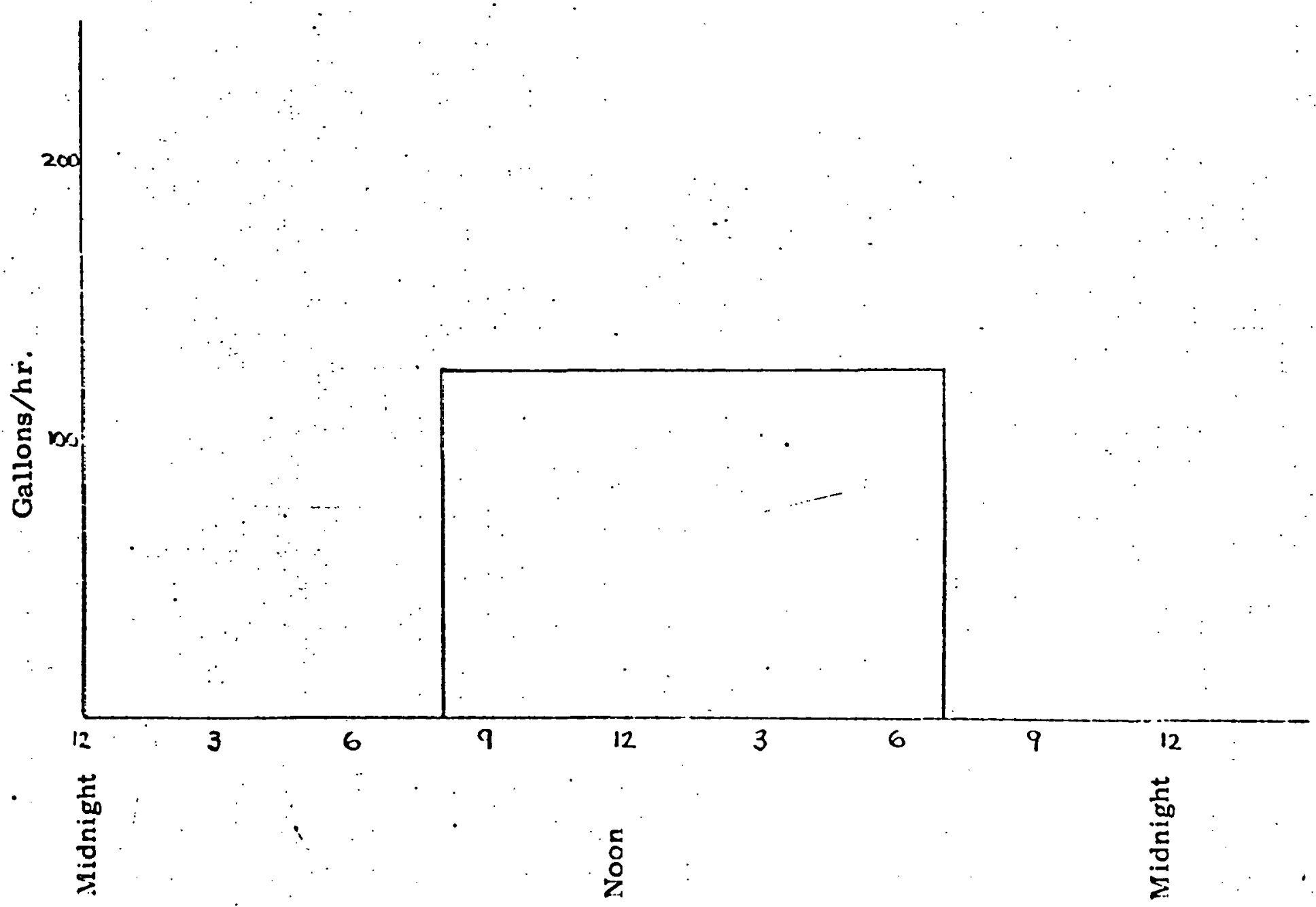

Time of Day 


\subsubsection{Weather Model}

The following hourly recorded data is taken from weather tapes provided by the National Climatic Center, Asheville, N. C. (Reference Airways TDF-14, Surface Observations Manual, Director National Climatic Center, Federal Building, Asheville, N. C., 28801).

Dry Bulb Temperature

Dew Point Temperature

Wet Bulb Temperature

Wind Speed

Barometric Pressure

Total Cloud Cover

Type of Cloud

Occurrence of Wet Precipitation

Occurrence of Dry Precipitation

\subsubsection{Flat Plate Collector Model}

The flat plate model is based on a tilted flat plate facing south. Although the model allows both the tilt and direction to be specified, they are held constant for any one simulation run. The amount of energy cullecled is expressed by:

$$
\mathrm{Q}_{\text {out }}=\mathrm{K}_{1} \mathrm{Q}_{\text {ine }}-\mathrm{K}_{2}\left(\mathrm{~T}_{\text {in }}-\mathrm{D}_{\mathrm{b}}\right)
$$

where:

$Q_{\text {inc }}=$ Amount of solar radiation incident on the collector surface

$\mathrm{T}_{\text {in }} \quad=$ Temperature of input tiluid

$\mathrm{D}_{\mathrm{b}} \cdot=$ Dry bulb temperature

$\mathrm{K}_{1}, \mathrm{~K}_{2}=$ Constants for proposed Lennox collector 
For 2 cover collector:

L

$$
\begin{aligned}
& \mathrm{K}_{1}=.74 \\
& \mathrm{~K}_{2}=.6
\end{aligned}
$$

For 1 cover collector

$$
\begin{aligned}
& \mathrm{K}_{1}=.8 \\
& \mathrm{~K}_{2}=.68
\end{aligned}
$$

\subsubsection{Storage}

Energy storage is accomplished through the sensible rise in temperature of a tank filled with water. For the purposes of our analysis, an insulated cylindrical steel tank with specified length and diameter was assumed. Energy supplied to the tank was assumed to be evenly distributed to all segments.

Two types of insulation for reducing heat loss from the tank were considered - fiberglass and urethane. The thermal conductivity of these materials are:

$$
\begin{aligned}
& \mathrm{k} \text { (fiberglass) }=.26 \mathrm{Btu}-\mathrm{in} / \mathrm{HR} \mathrm{ft}{ }^{2} \mathrm{~F} \\
& k \text { (urethane) }=.13 \mathrm{Btu}-\mathrm{in} / \mathrm{HR} \mathrm{ft}^{2} \mathrm{~F}
\end{aligned}
$$




\subsubsection{Economic Studies}

A computer subroutine is being used to make economic comparisons between alternate systems and subsystems. The economic evaluations are based on annual cost requirement. The methodology for calculation of the annual cost requirement is based on formulas derived by Grant and Ireson" and Rosalie T. Ruegg.

Figure 5.3.13-1 shows a diagram that summarizes the procedure. The output is the annual revenue requirement and is the average dollar amount that would be required each year to cover the cost of operating and paying for the solar system.

The basic inputs needed for the procedure are as follows:

- System cost

- Annual hours of equipment operation (i.e. pumps and fans)

- Energy demand for the building

- Maintenance and major replacement costs

- Energy costs

- Energy escalation rates

- Cost of money

Fuel costs are shown separately because it is expected that electricity will escalate at a different rate than natural gas or oil. Also maintenance costs are separate since the timing of maintenance may not be demanded at a constant rate whereas the operating costs will be constant.

"Eugene L. Grant and W. Grant Ireson, Principles of Engineering Economy, Ronald Press Company, New York, 1964.

*** R. T. Ruegg, "Solar Heating and Cooling in Buildings: Methods of Economic Evaluation", NBSIR 75-712. 


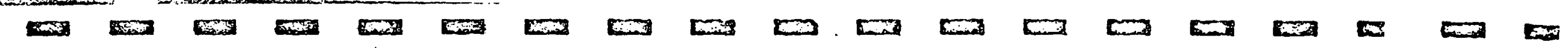

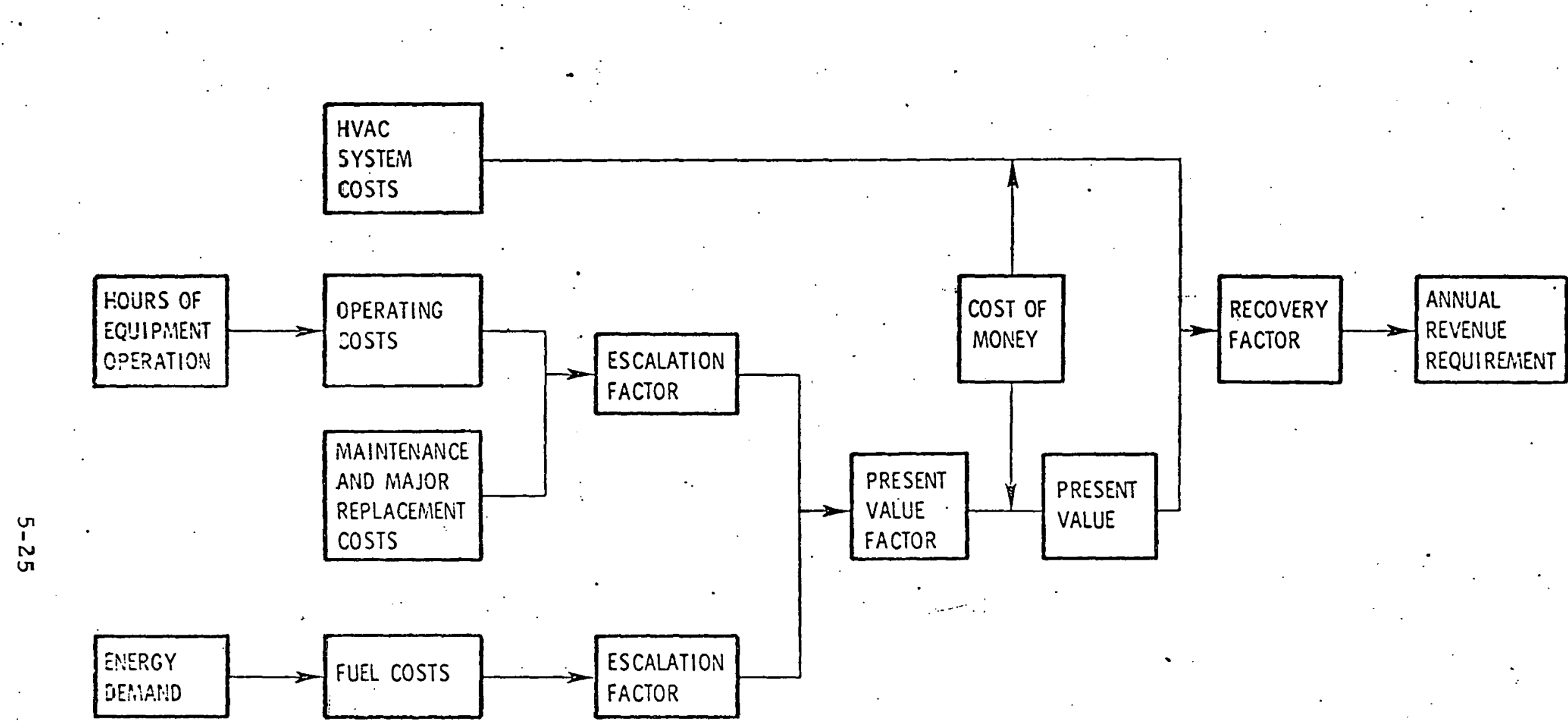

LEVEL ANNUAL REVENUE REQUIREMENT

Figure 5.3.13-1 
The system operating costs, including fuel and equipment operating. is brought to an equivalent basis for comparison purposes by computing the present value. The formula for this is:

$$
P V=\frac{1}{(1+i)^{n}}
$$

where $\mathrm{i}=$ interest rate or cost of money and $\mathrm{n}=$ number of interest periods or years. The interest rate selected for the study was $7 \%$. The economic subroutine in the computer simulation allows for inserting various interest rates for study purposes.

The annual cost required by the homeowner to pay for the system . as well as the operating and energy costs is predicted by summing the present value of fuel and operating costs over the life of the system, adding the system first cost and then reducing this amount to a uniform payment by the capital recovery factor formula.

$$
C R f=\frac{i(1+i)^{n}}{(1+i)^{n}-1}
$$

For a 20 year interest period and $7 \%$ interest, the capital recovery factor is 0.09439 .

The maintenance costs have been neglected. Also not included are allowances for increases in property tax, increases in insurance, or other factors which might incrcasc of decrease payments: Salvage value of equipment at the end of the amortization period was not considered. 
5.3.14 Cost of Energy

The cost of natural gas, oil and electricity for Minneapolis for 1976 were based on current rate schedules recently obtained from Northern States Power Company, Minneapolis Gas Company and Mobile Oil Company. These current rates are as follows:

Natural gas: $\left(1000 \mathrm{Btu} / \mathrm{ft}^{3}\right)$

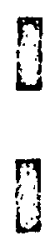

$\frac{\mathrm{ft}^{3}}{300}$

$0-300$

$300-3700$

$3700-26000$

26000 -

Oil: (14000 Btu/gal)

No. 2

Electricity:

Fixed charge per month -

First $500 \mathrm{KWH}$ per KWH -

Next $500 \mathrm{KWH}$ per KWH

For excess per KWH $\frac{\$}{2: 4603}$

$1.9790 / 1000 \mathrm{ft}^{3}$

$1.5590 / 1000 \mathrm{ft}^{3}$

$1.5090 / 1000 \mathrm{ft}^{3}$

$.393 /$ gal .

2.50

.0353

.0309

.0190

5.3.15 Projected Cost of Energy

to

There appears to be many scenarios for the escalation of energy in the future. While future availability problems are speculative, the critical nature of energy use in todays society will obviously result in increased fuel costs. Energy costs, unless regulated nationally, will escalate at different rates for each geographical area. 
The escalation rates assumed are the rates presented at the NASA contractors meeting of 3 August 1976. (Reference A. D. Little, "Base Prices and Forecast", April, 1974).

\begin{tabular}{|l|c|c|c|}
\hline \multirow{2}{*}{ Energy } & \multicolumn{2}{|c|}{ Year } & \multirow{2}{*}{ Rate } \\
\cline { 2 - 4 } Electricity & 1976 & 2000 & $(1.014)^{24}=1.4$ \\
Gas & 1 & 1.4 & $(1.043)^{24}=2.72$ \\
Oil & 1 & 2.72 & $(1.022)^{24}=1.68$ \\
\hline
\end{tabular}

5.3.16 Example of Economic Procedure

The following example shows the econamics procedure for a solar assisted $1500 \mathrm{ft}^{2}$ residence in Minneapolis. For present day energy costs (1976) and energy demands based on ASHRAE standard 90-75, the following yearly demands and prices are predicted:

$\begin{array}{ll}\text { Heating demand } & 106.6 \mathrm{MBtu} \\ \text { Solar supplied to heating } & 45.4 \mathrm{MBtu} \\ \text { Electric demand (pumps) } & 2358 \mathrm{KWH} \\ \text { Ilot water demand } & 3.4 \mathrm{MBtu} \\ \text { Solar supplied to hot water } & 2.1 \mathrm{MBtu} \\ \text { Fucl cost } & \$ 3.6 / \mathrm{MBtu} \\ \text { Electric cost } & \$ 10.43 / \mathrm{MBtu}\end{array}$

Assuming electricity escalates at $1.4 \%$ per year and natural gas at $4.3 \%$ per year, the total energy costs over the next 20 years come to $\$ 6572.49$ which represents a present value of $\$ 3462.54$ at an interest rate of $7 \%$.

In other words, $\$ 3462.54$ invested at $7 \%$ interest would generate enough money over the next 20 years to meet all the energy costs as they occur. 
月

The solar system costs are approximately $\$ 11,000$ for a $540 \mathrm{ft}^{2}$ solar collector/array system. These costs added to the total energy costs of 3462.54 gives $\$ 14,462.54$. Assuming a 20 year pay period with interest of $7 \%$ would yield an annual homeowner payment for both the system and operating costs of

$$
\begin{aligned}
\text { payment } & =14462.54(\mathrm{CRf}) \\
& =14462.54 \quad(.09439) \\
& =\$ 1365 . \\
& =\$ 113.75 / \mathrm{mo} .
\end{aligned}
$$

H

.

I

留

(1)

8

B

8

8

8

8 
5.4. Simulation Description

Honeywell has developed a general purpose computer program (SUNSIM) for use in closed loop solar system simulation. This computer program has been adapted for use in the design and evaluation of the solar heating and cooling demonstration systems.

Component relationships and loop constraints a re used in the SUNSIM computer program to model multiple loop solar systems as sets of nonlinear differential equations. The differential equation may be integrated forward in time to determine fuel savings or linearized numerically for stability analysis using a fully automated modern control software package.

The closed loop simulation structure, illustrated in Figure 5.4-1 consists of three key functional blocks:

- A MAIN program which inputs data, controls the integration and linearization of the differential equations, samples the output and generates report quality output plots and tables.

- A first order Adams-Bashforth integration STEP routine which updates state variables based on current and past values of the derivatives.

- A DERIVative routine which contains the differential equations used to model the system.

A derivative subroutine contains deterministic functions of time such as the diffuse and direct components of solar radiation on cloudy days and hourly weather data available for over 300 weather stations in the United States. Two different models may be used to compute the diffuse and direct components of solar radiation. 
MAIN PROGRAM

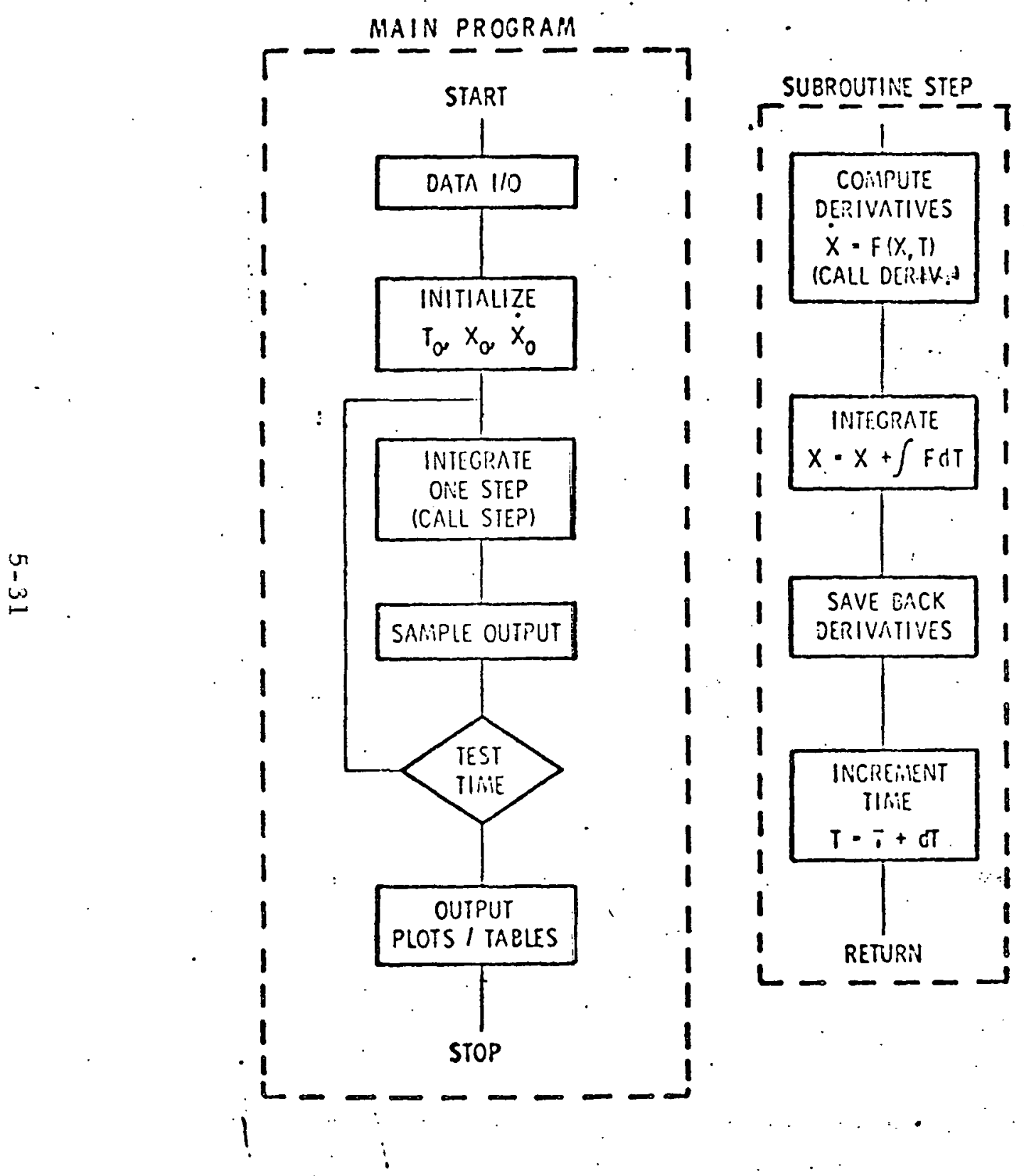

SUBP.OUTIRE DERIV.

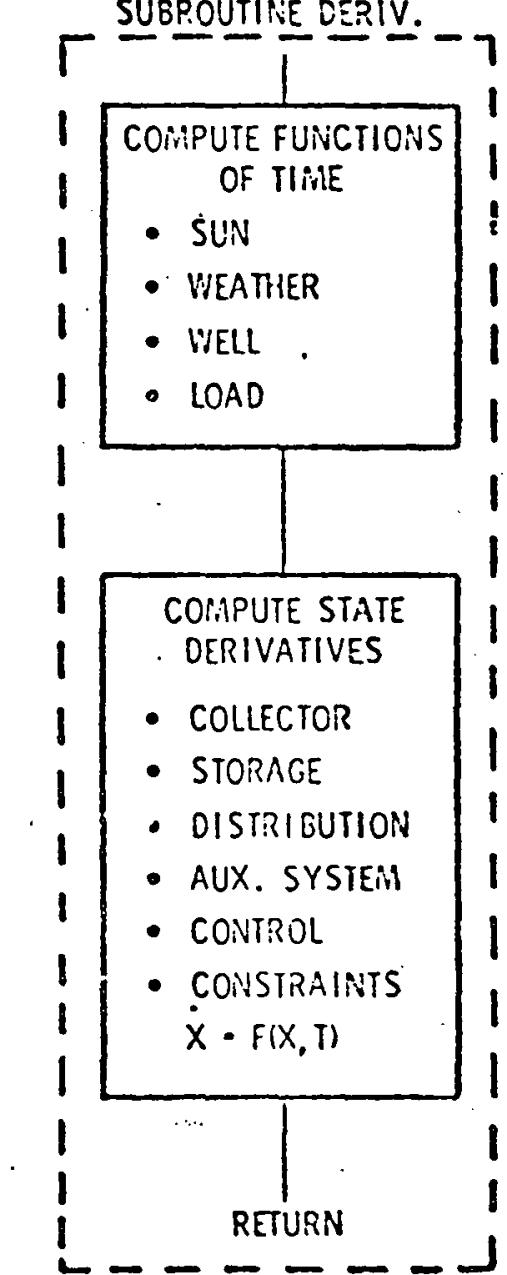

Closed Loop Solar System Simulation Structure

Figure 5.4-1 
- An ASHRAE procedure based on weather data provided by the National Climatic Center and a cloud cover radiation model due to Kimura and Stephenson.

- Actual measurements of total radiation on a horizontal surface with an analytical estimate of diffuse and direct components based on a Liu-Jordan correlation. The radiation data is provided on tapes by the University of Wisconsin.

In addition, the DERIVative subroutine contains performance models for solar and conventional system components commonly used in shallow solar ponds, flat plate, Fresnel and trough concentrator systems. The simulation is modular in structure and well documented to minimize modeling time required for the different types of systems.

Figure 5.4-2 illustrates four modes of the solar HVAC system presently being considered for residential space heating and hot water. The four modes of the system modelled are:

- Mode 1 -- no solàr, auxiliary when needcd, hot water from storage when available.

- Mode 2 -- space heating in the direct mode and hot water heating.

- Mode 3 -- space heating from storage and hot water heating.

o Mode 4 -- storage charging and heating hot water. 


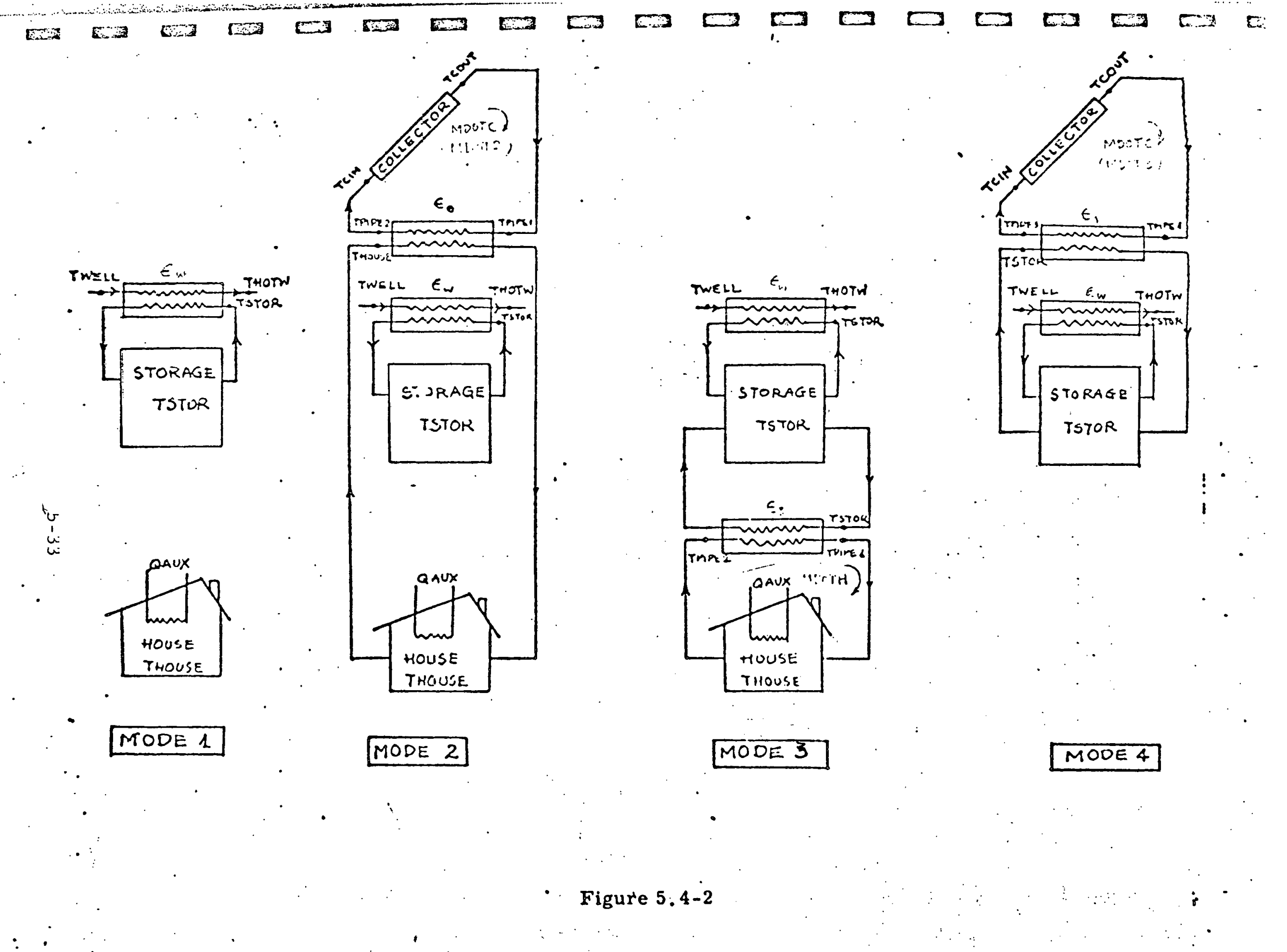


A first order model of this system has been constructed for use in computing annual fuel savings in support of system design trades. The effect on annual system performance of all major design variables including finite heat exchangers, pumping power, distribution system sizing and insulation, storage tank volume and insulation, loop flow rates and collector manifolding configurations can be readily evaluated with this simulation.

In this simulation, relatively high frequency transients associated with the collector loop thermal capacitance are neglected. As a result, an iterative procedure is required at every integration step to determine the collector loop temperatures in order to satisfy an energy balance constraint on the differential equations.

Simulation of space heating systems and industrial process heat systems have also been conducted using the SUNSIM computer program in which the effects of collector loop thermal capacitance on system dynamics and performance were considered. These simulations required integration steps ranging from 30 seconds to 6 minutes and are primarily used for stability analysis and the investigation of short period effects such as limit cycle frequencies and amplitudes. 
$5.5 \quad$ Results

Performance and economic simulations of the selected solar assisted heating system was performed for systems for single family residences, multifamily residences and commercial buildings. The trade-off studies began with a "standard" system and various parameters were varied separately to determine their effect on system performance and economics. The effects of these parameter variations have been studied only for Minneapolis and the magnitude of the effects would be different for different locälities.

\subsubsection{Single Family Residence (SFR)}

The basic solar system modelled in the digital simulation program is shown schematically in Drawing SK140094 consists of a collector array with piping headers on both sides of the collectors for inlet and outlet of the collector fluid, a collector with 2 glass covers and a single storage tank filled with water for sensible heat storage. The most important variable which greatly effects both performance and economics is the. collector area.

The collector area for the SFR was varied from $180 \mathrm{ft}^{2}$ to $756 \mathrm{ft}^{2}$. Figure 5.5,1-1 shows the percent of solar energy supplied to a SFR varies from about 21 percent for $180 \mathrm{ft}^{2}$ of collector area to about 45 per-. cent for a $756 \mathrm{ft}^{2}$ system. These predictions were made for a system with a 1000 gallon storage tank. From this curve, it is not obvious what size. system to install since the percent of energy increases as the system collector area increases. 
An analysis of the economics of the system by the method described in Section 5.3.13 shows that a minimum cost per million Btu's of solar energy provided is realized with a solar system with approximately $540 \mathrm{ft}^{2}$ of collector. This is shown in Figure 5.5.1-2. The minimum cost per million Btu's provided is approximately $\$ 34 / \mathrm{M} 3 \mathrm{tu}$.

Collector tilt is important. Figure 5.5.1-3 shows that $55^{\circ}$ is optimum which corresponds closely to the rule of thumb of latitude plus $10^{\circ}$ for heating systems. The performance is within 1 percent of maximum over the range of $45^{\circ}$ to $65^{\circ}$. The economics of the system operation for various collector tilt angles is presented in Figure 5.5.1-4. The optimum tilt angle is $55^{\circ}$ as was shown in the performance curve (Figure 5.5.1-3).

The performance of the system with the collector array facing away from south was not simulated. It is well known that the optimum system performance is achieved with collectors facing due south. Previous calculations have shown that variations of $30^{\circ}$ east or west reduce performance about 3 percent.

The performance of a $540 \mathrm{ft}^{2}$ solar system with different size storage tanks is shown in Figure 5.5.1-5. The percent of solar energy supplied to the load varies from about 23.5 percent for a 125 gallon tank to approximately 42 percent for a 1500 gallon tank. The optimum size storage tank is more obvious from curves shown in Figure 5.5.1-6. An analysis of the figure shows that the cost per million Btu's provided decreases rapidly to about 600 gallons and then decreases more gradual up to 1500 gallons. This is approximately 1.11 to 2.5 gallons per square foot of collector. A 1000 gallon storage tank was selected as the preferred size. 
The heat loss from the storage tank was investigated. Figure 5.5.1-7 shows that for a storage tank UA of 9.44 (4 inches of fiberglass), the system would provide about 2 percent less over the year than if no heat was lost from storage. If the storage tank is located inside the building, the heat loss would decrease the building heat load and the net effect would be the same as a perfectly insulated storage tank.

The baseline solar systems described in Section 4.0 have two heat exchangers between the solar collectors and the building air. Figure 5.5.1-8 shows that the performance of the solar system varies approximately 2 percent for a range of heat exchanger heat transfer effectiveness.

A method to cut the cost of solar energy systems is to reduce the piping and solar collector header costs. This can be accomplished by mounting two flat plate collectors in series. The exit flow of one collector enters the second collector directly. Fluid exiting from the second collector then goes into the piping header. The disadvantage of this arrangement. is that the performance of the second collector in series is degraded because the fluid inlet temperature is higher. The performance of solar system with the collectors arranged in series is only degraded by a fraction of a perecnt.

The solar collector can be configured with one cover. This results in the performance equation of the collector having a greater $\alpha \tau$ but also a larger heat loss, $U_{L}$. The performance effect of one cover collector versus a two cover collector is presented in Figure 5.5.1-9. The figure shows that the one cover collector provides approximately 2 percent more energy over the year. Figure 5.5.1-10 presents the cost per million Btu's versus the number of collector covers. This figure shows that the overall cost is reduced for the one cover collector. 
Figure 5.5.1-1

\section{PERCENT OF ENERGY SUFPLIED BYY SOLAR}

VS.

COLLECTOR AREA

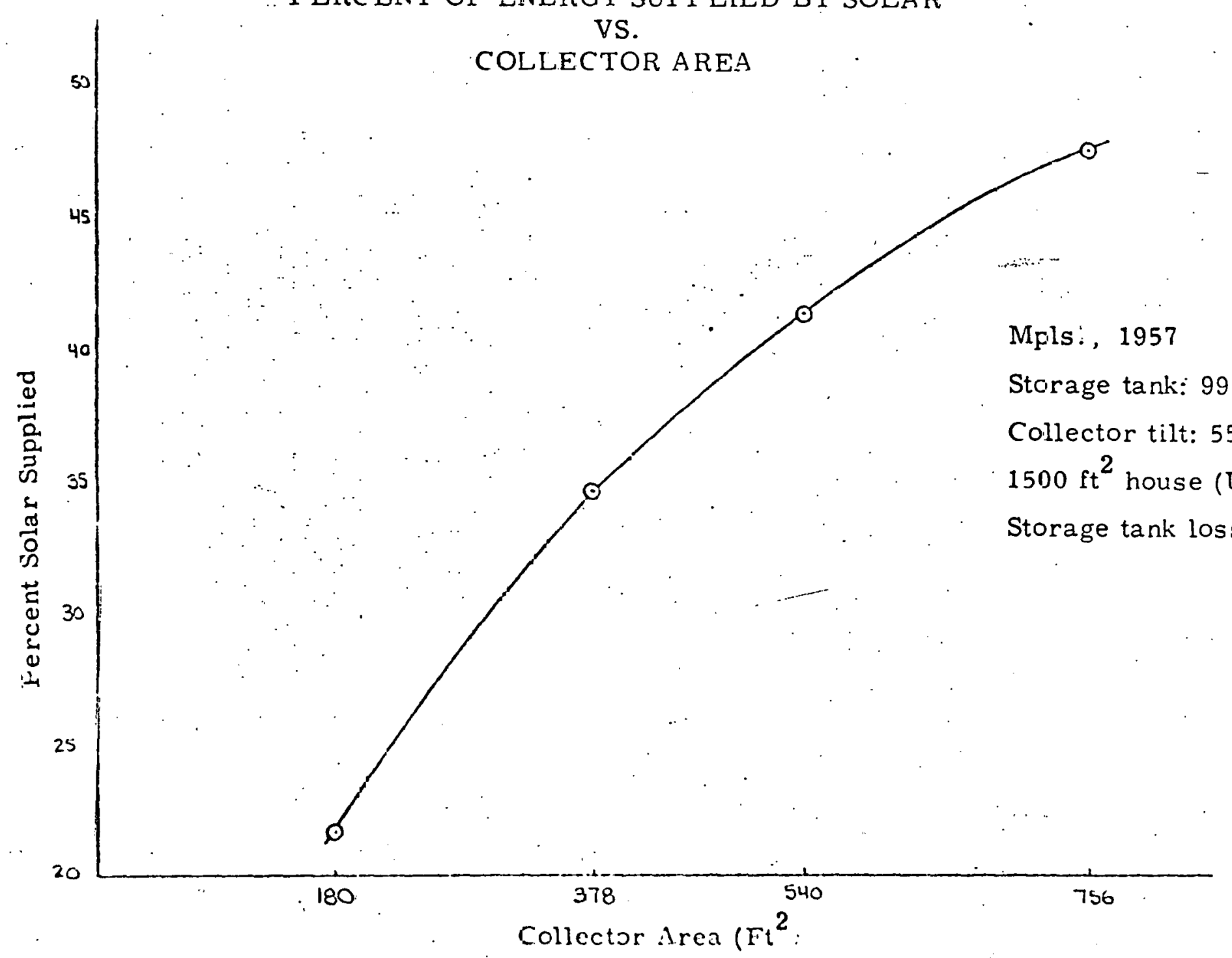


DOLLARS PER MILLION BTU'S OF SOLAR ENERGY

VS.

COLLECTOR AREA

SINGLE FAMILY RESIDENCE

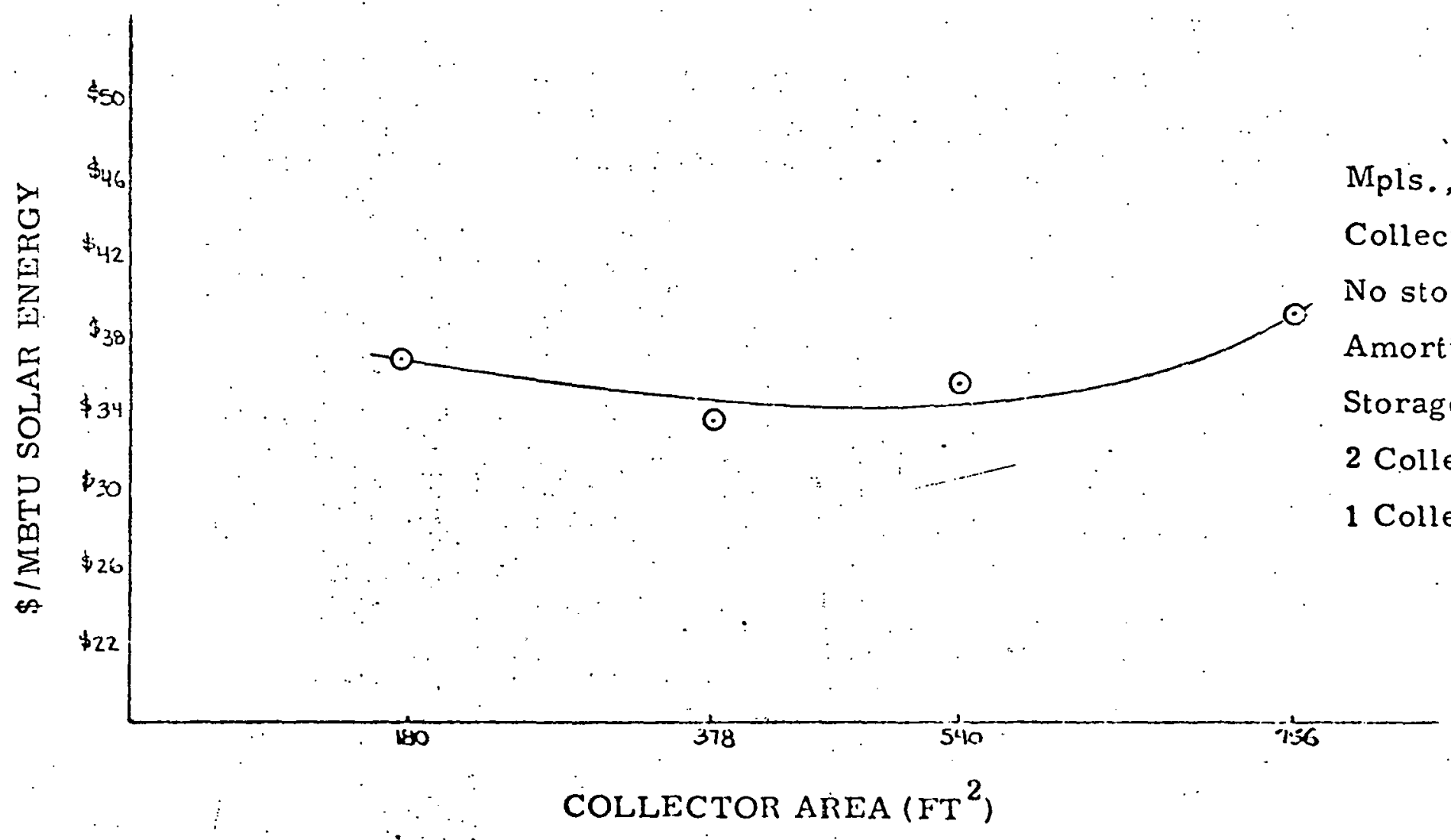




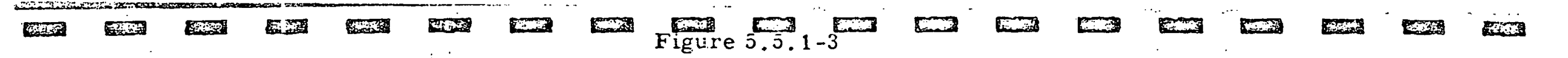

FERCENT OF ENERGY SLFF LIED BY SOLAR

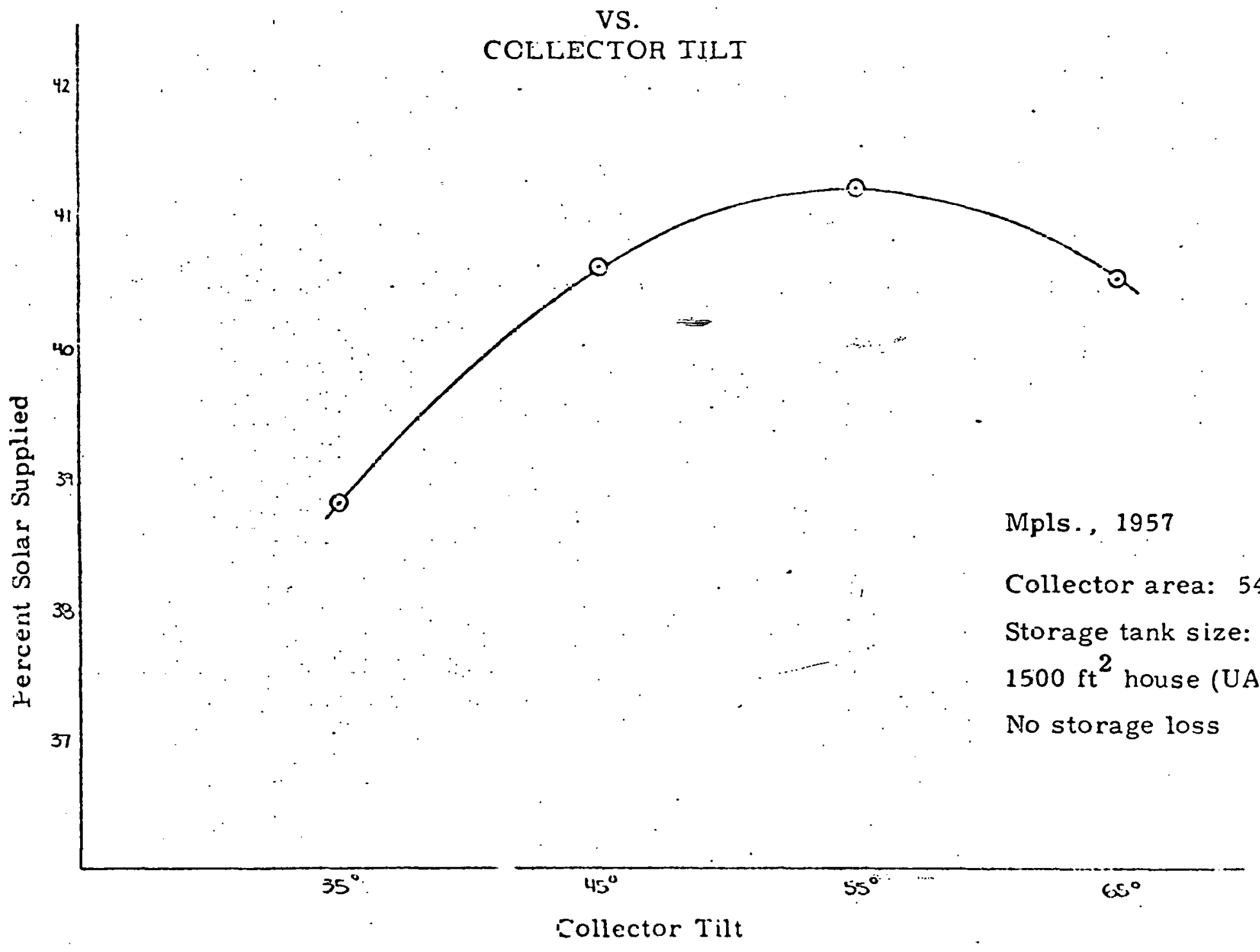


DOLLARS PER MILLION ETUS OF SOLAR ENERGY

VS.

COLLECTOR.TILT

Mpls., 1957

Amortization: 20 yrs. at $7 \%$

Collector area: $540 \mathrm{ft}^{2}$

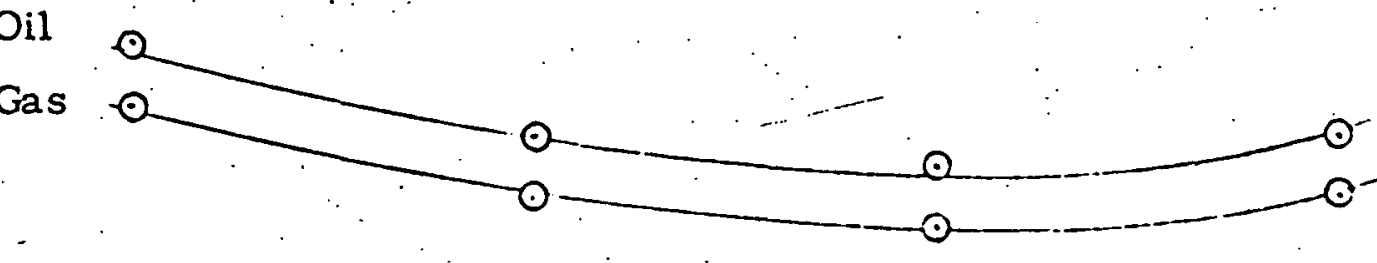

Storage tank size: $1000 \mathrm{gal}$

$1500 \mathrm{Ft}^{2}$ House (UA $=473$ )

No storage loss

2 Collector covers

$35^{\circ}$

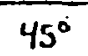

S5

Collector Tilt 

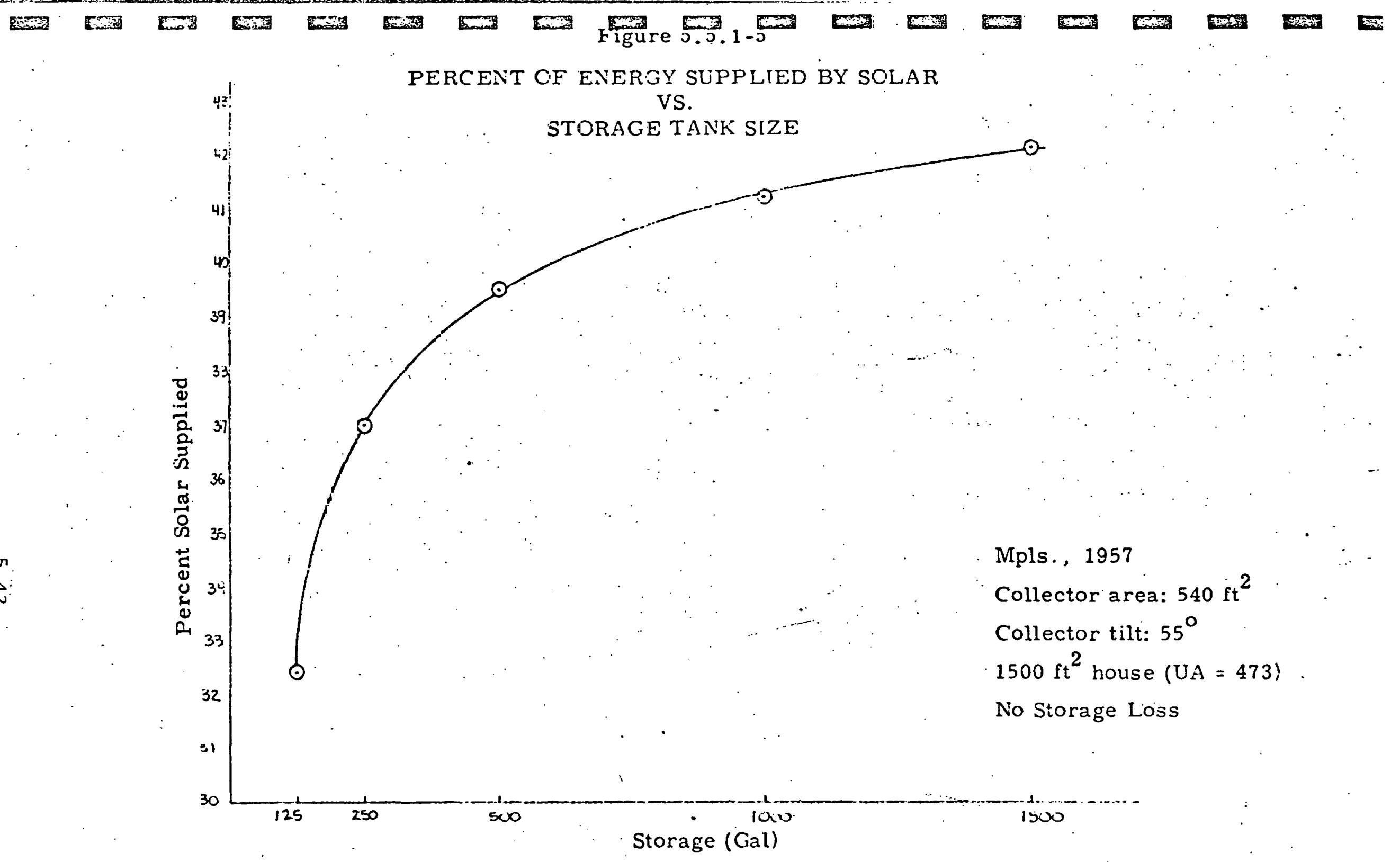


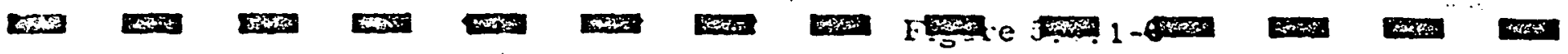

DOLLARS PER MILLION BTLS OF SOLAR ENERGY vS.

STORAGE TANK SIZE

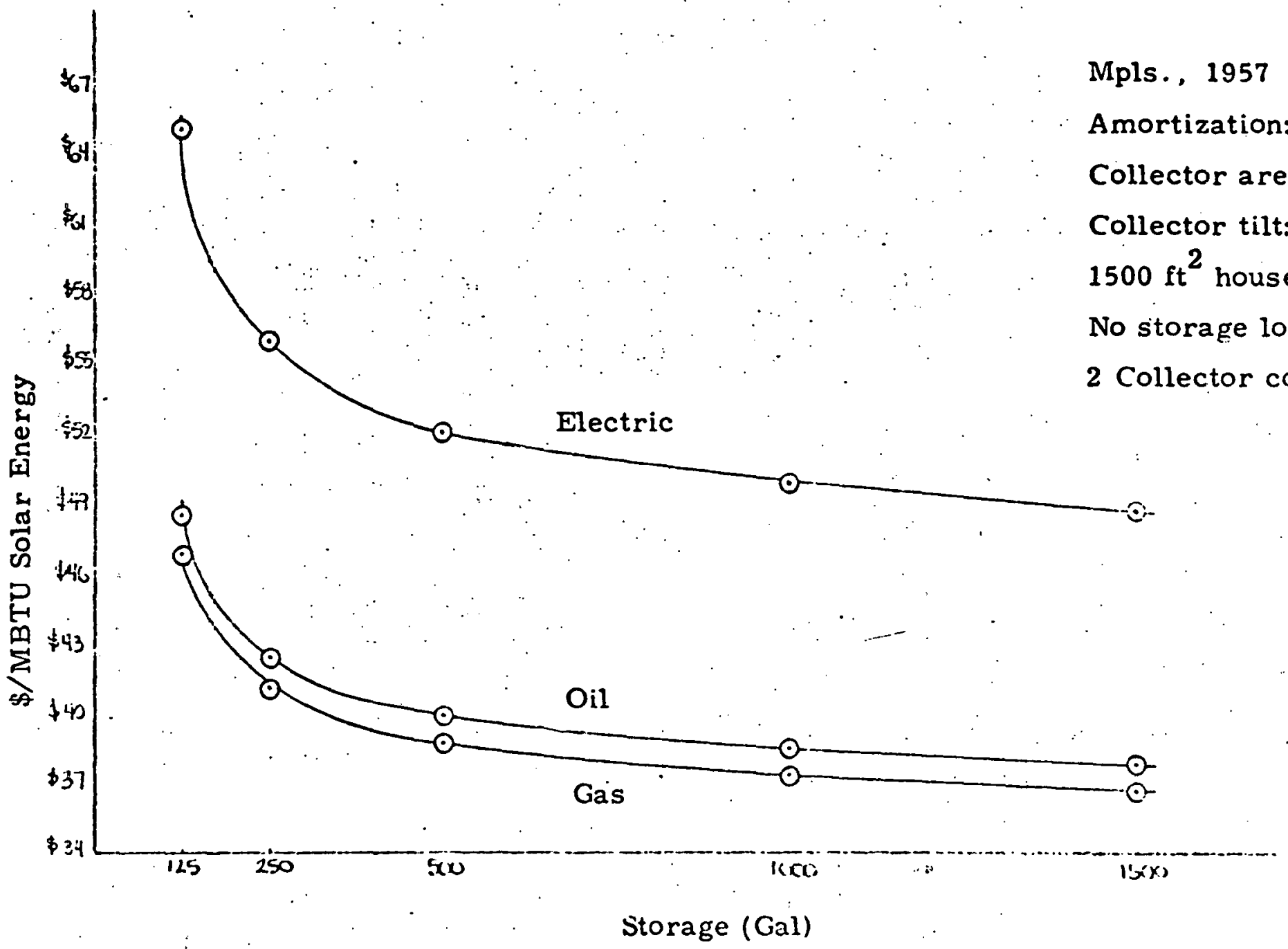

$\frac{125}{\$ 250} \frac{1500}{\text { Cost of Storage Tank (\$) }}$




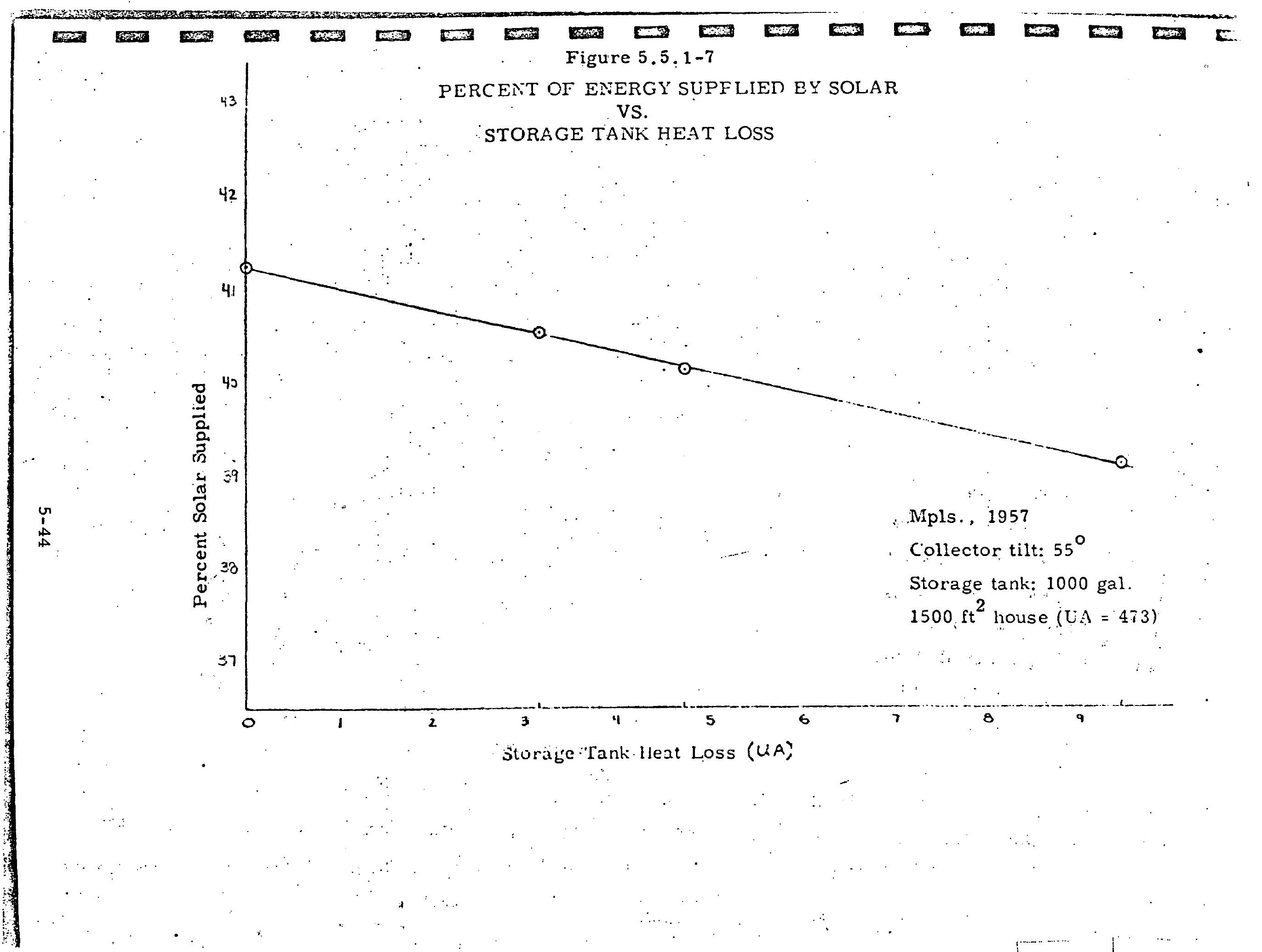


$\therefore$ FERCENT CF ENERGY SUFFLIED BY SOLAR

VS.

HEAT EXCHANGER HEAT TRANSFER EFFECTIVENESS

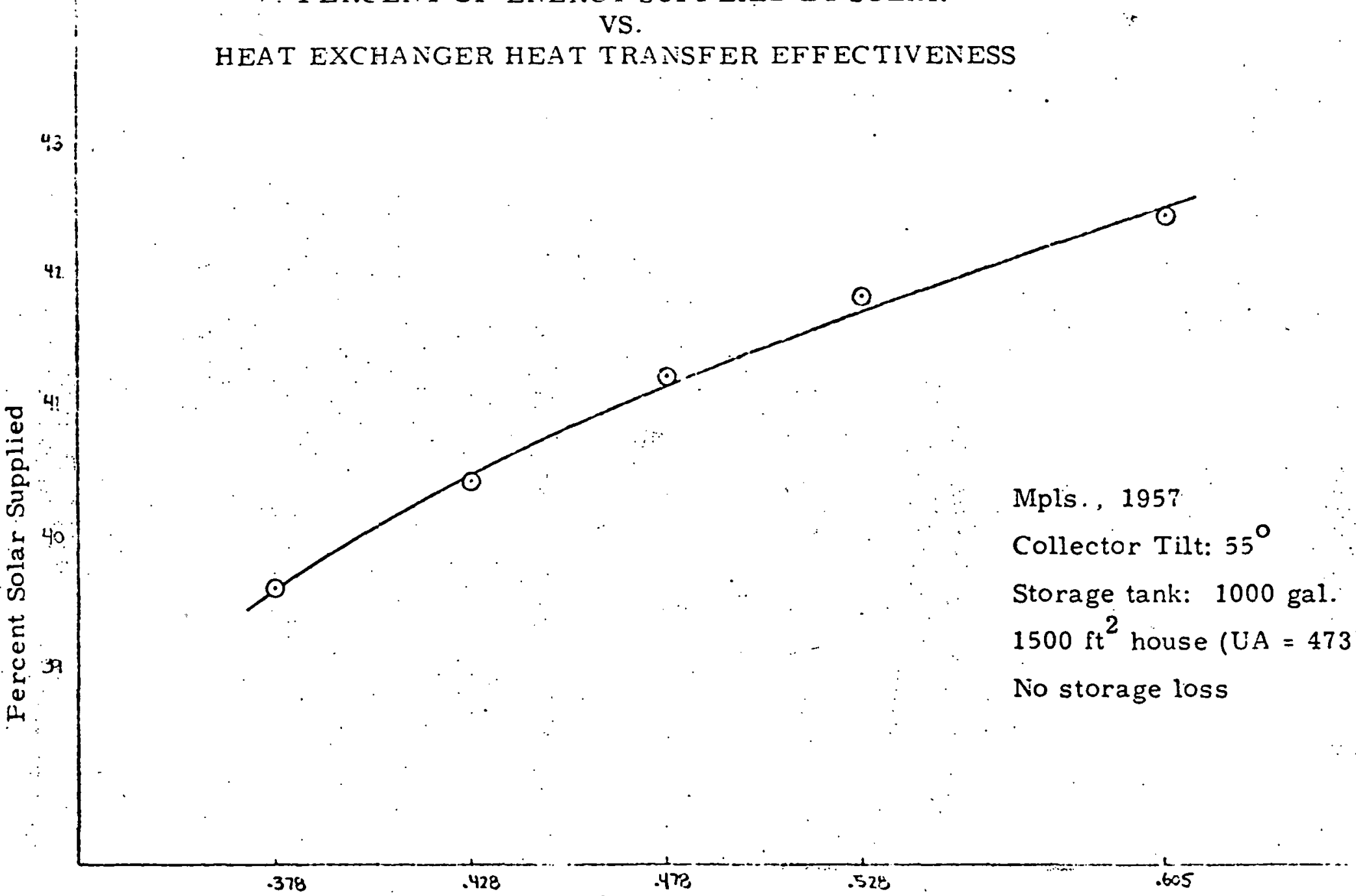

Heat Exchanger Heat Transfer Effectiveness - Collector to House H. E.

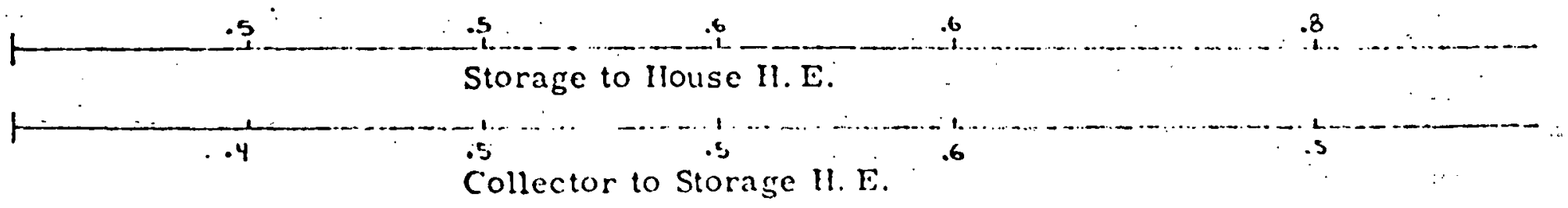


PERCENT OF ENERGY SUTFLIED BY SOLAR

VS.

NUMBER OF COLLECTOR COVERS

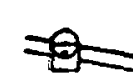

1 collector in series

2 collectors

in series

No. of Collector Covers
Mpls., 1957

Collector tilt: $55^{\circ}$

Storage tank: 1000 gal. $1500 \mathrm{ft}^{2}$ house (UA $=473$ : No storage loss 


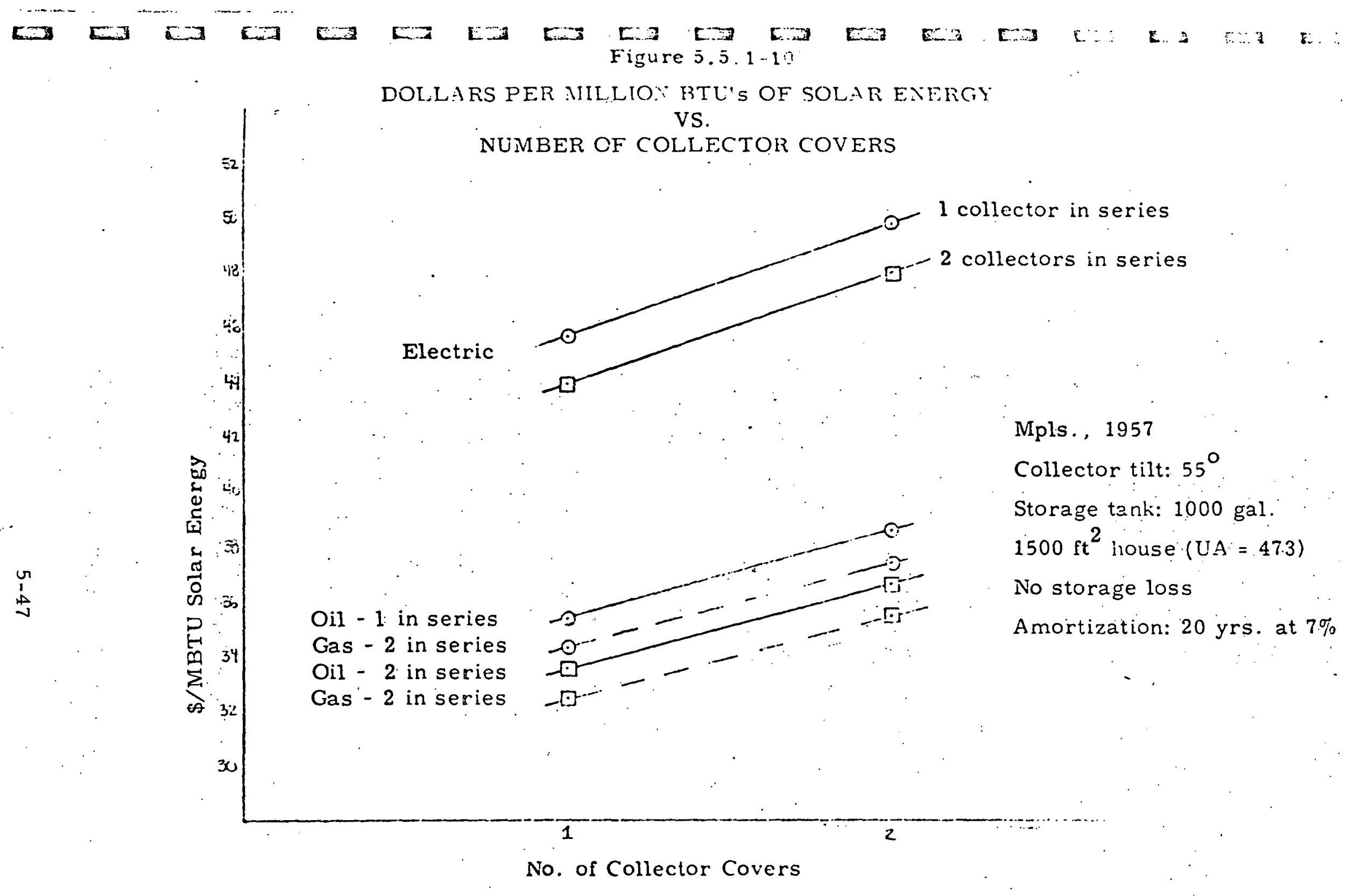




\subsubsection{Multifamily Residence (MFR)}

The basic solar system modelled in the digital simulation program is shown schematically in Drawing SK 140095. The results of the tradeoff for the SFR were used so that not all variables nceded to be studied. Since collector area is the most important variable, it was optimized. Figure 5.5.2-1 shows the solar cost as a function of collector area. The minimum cost system consists of 3780 squa re feet of collector or 210 collector modules.

\subsubsection{Commercial Building ( $C B$ )}

The baseline solar system model simulated in the digital computer code is shown in Drawing SK 140096. As in the multifamily system, the collector area was optimized. The performance of the system was predicted for collector areas of $2484 \mathrm{ft}^{2}$ to $11250 \mathrm{ft}^{2}$. The percentage of solar energy supplied to the building varies from 36 percent to 74 percent for the cases studied. Figure 5,5,3-1 shows the solar cost as a function of collector area for the commercial building. $\Lambda$ minimum cost per million Btu's supplied occurs at a collector area of $5500 \mathrm{ft}^{2}$. 
Figure 5.5.2-1

DOLLARS PER NILLION BTU'S OF SOLAR ENERGY

VS.

COLLECTOR AREA

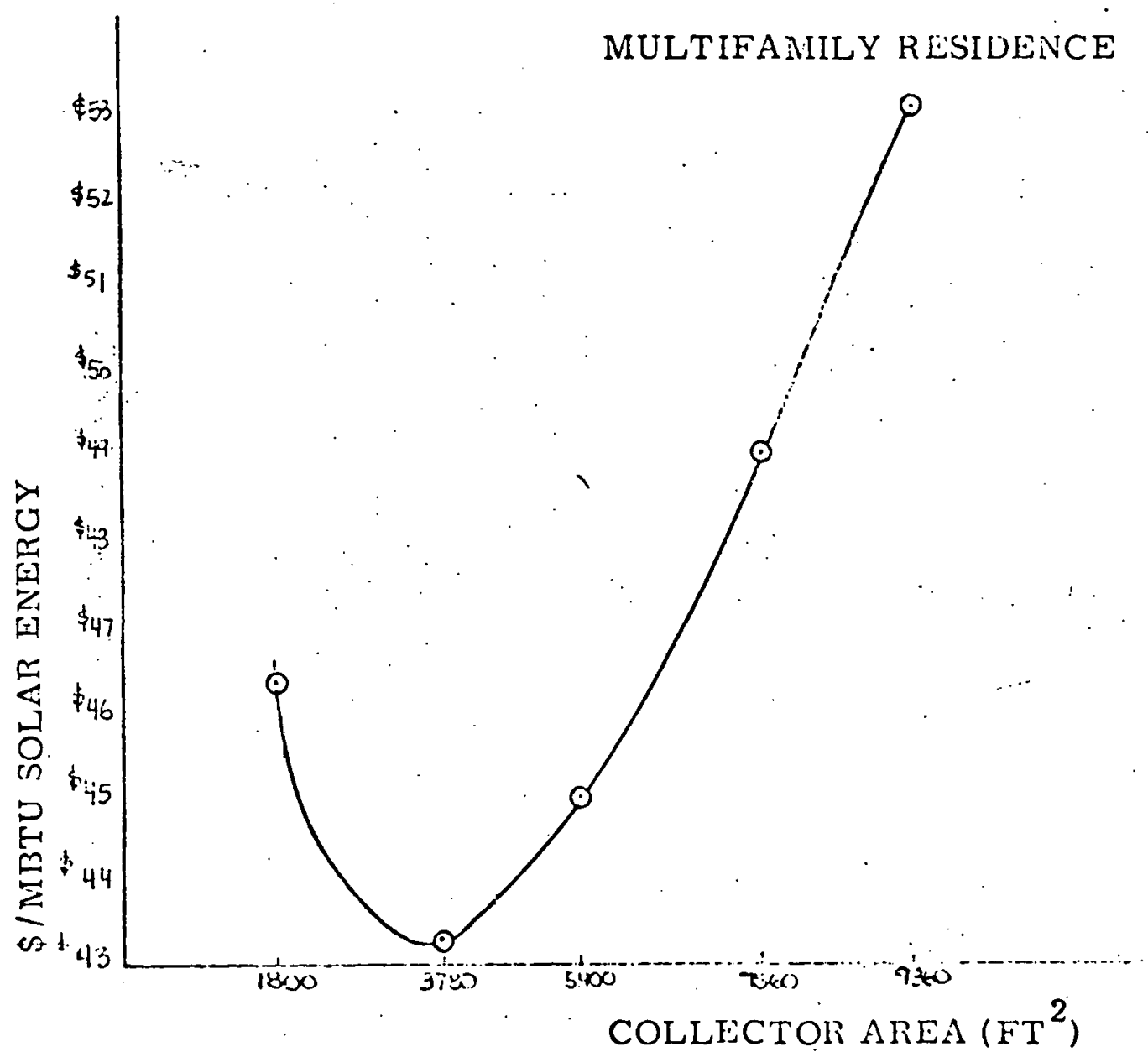

Figure 5.5.2-1
Mpls., 1957

Collector Tilt: $55^{\circ}$

No storage loss

Amortization: 20 yrs @ $7 \%$

Storage Tank: $1.5 \mathrm{gal} / \mathrm{ft}^{2}$ of collector

2 Collector covers

2 Collectors in series 
5

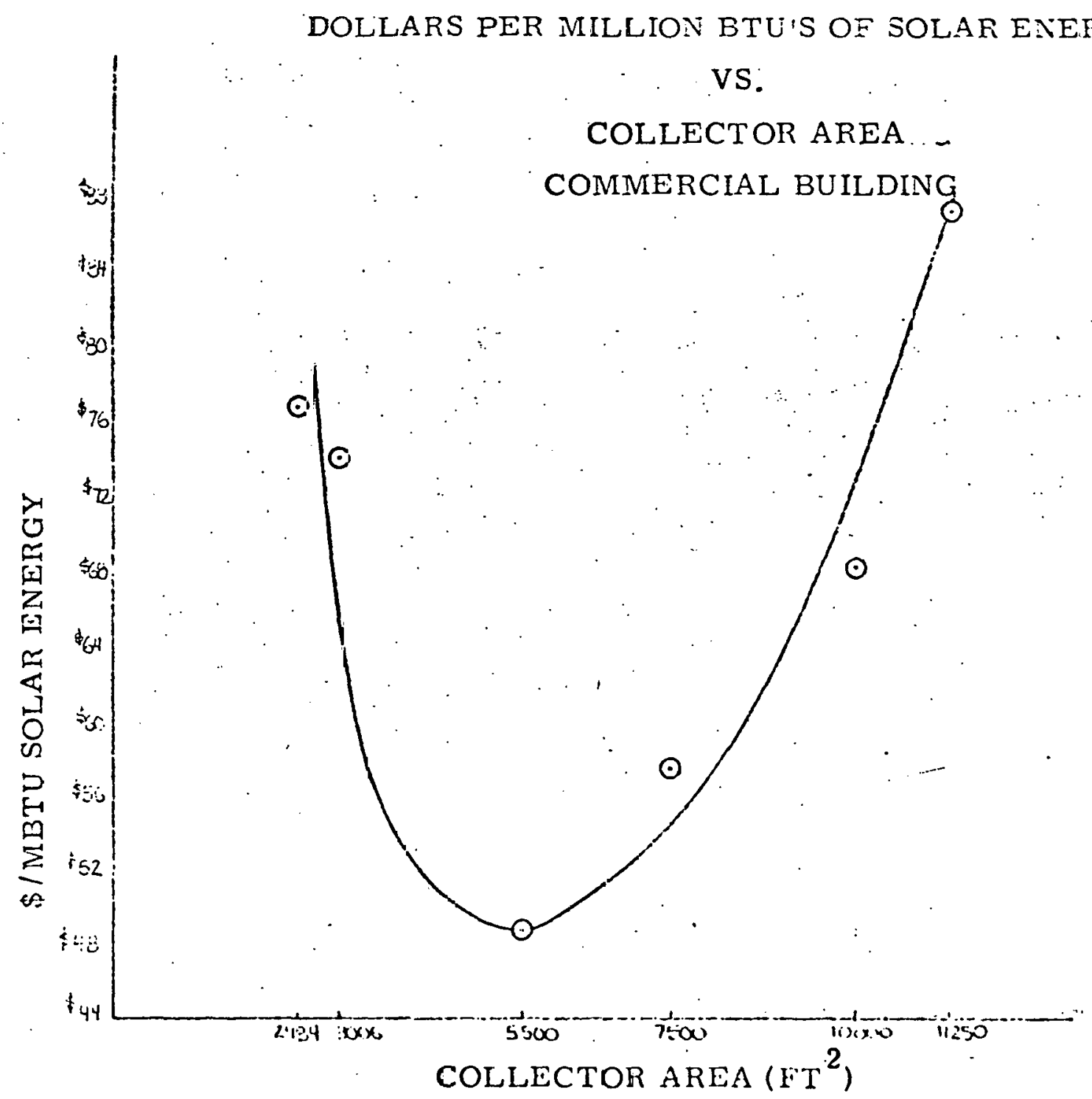

Mpls., 1957

Collector Tilt: $55^{\circ}$

No storage loss

Amortization: 20yrs @7\%

Storage rank: $1.5 \mathrm{gal}^{\mathrm{ft}}{ }^{2}$ of Collector

1 Collector cover

2 Collectors in series

Figure 5. 5.3-1 
6.0 Recommended Design

\subsection{Single Family Residence}

The recommended solar assisted heating system for a single family residence is a hydronic-to-warm air system with domestic hot water preheat. The system consists of the following major components:

- 540 square feet flat plate collectors (1 cover)

- Collectors assembled in series-parallel network

- 1000 gallons storage (water)

- Warm air furnace with hot water coil unit

The performance of this system for a Minneapolis $1500 \mathrm{ft}^{2}$ house. is shown in Figures 6.1-1 and 6.1-2: The space heating load for a typical year is $106.6 \times 10^{6}$ Btu of which $45.4 \times 10^{6}$ Btu or 42 percent is supplied by solar energy. The yearly service hot water load is $3.4 \times 10^{6}$ Btu of which $2 \times 10^{6}$ Btu or 60 percent is supplied by solar.

The operation of the pumps and furnace fan for the system consume $2358 \mathrm{KWH}$ electricity. The auxiliary fuel cost for a gas furnace is $\$ 153$.

This system is applicable to new construction as well as retrofit buildings.

As an alternate, an oil furnace could be installed as an auxiliary. The cost of its operation, based on $40 \$ /$ gallon oil prices would be approximately $\$ 218$ per year. If an electric resistance furnace is installed, the auxiliary fuel costs per year would be about $\$ 638$ based on $\$ .0356 / \mathrm{KWH}$. 
A heat pump could also be used to supply the auxiliary energy. Assuming the air-to-air heat pump has a seasonal performance factor of 2.5 , the auxiliary energy costs for heating would be $\$ 255$ per year. 


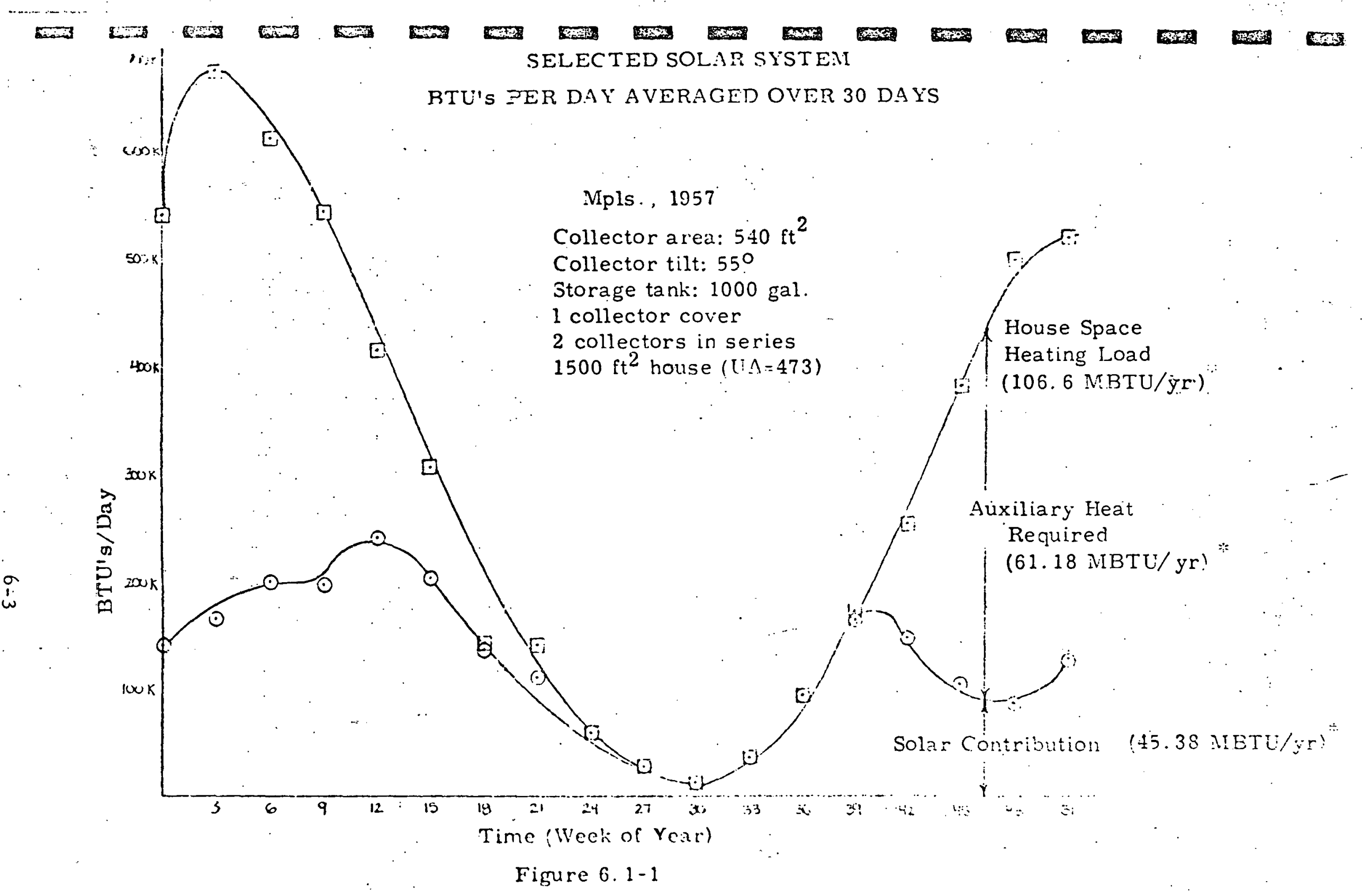




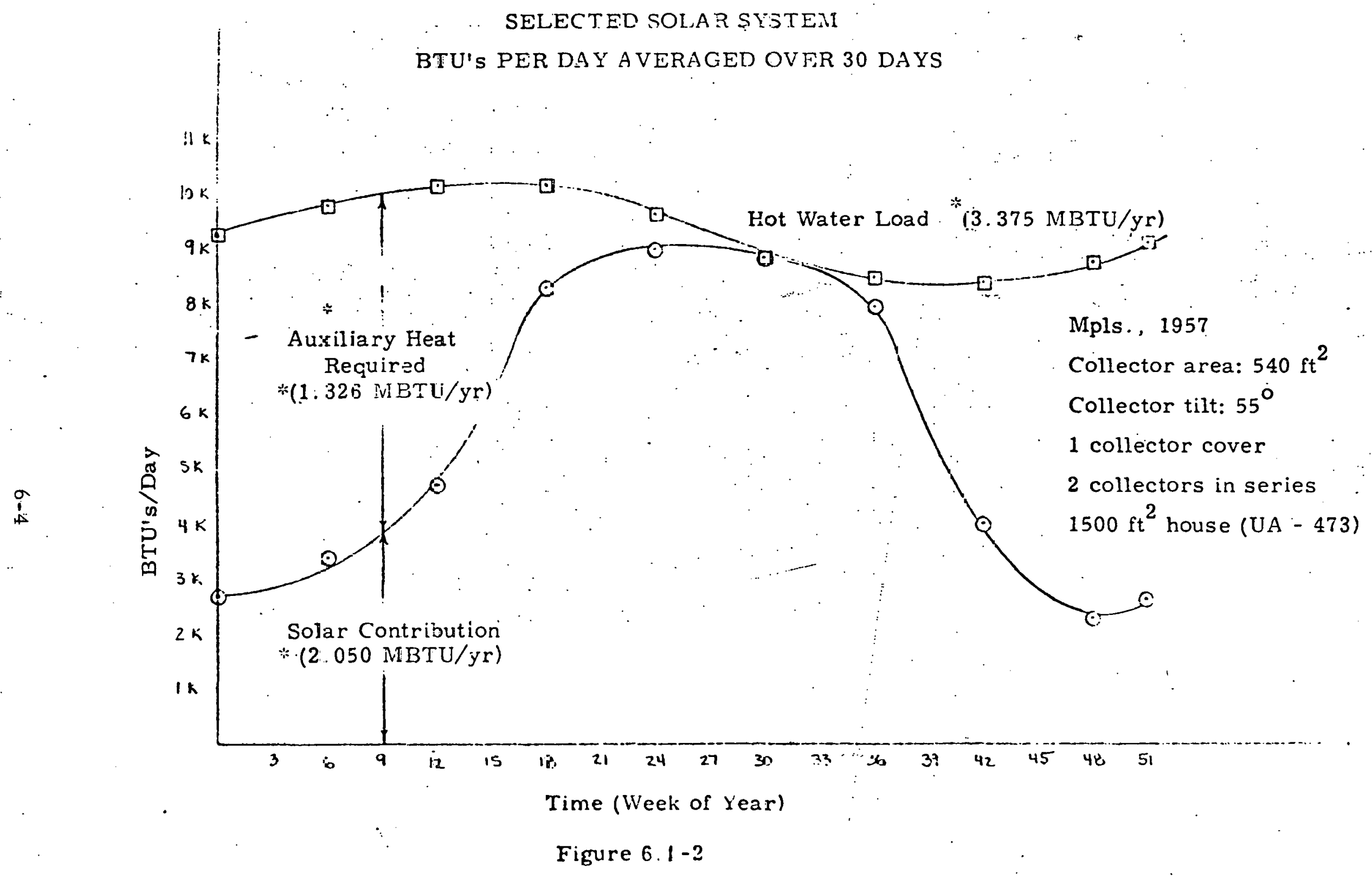




\subsection{Multifamily Residence}

The recommended solar assisted heating system for a multifamily residence is a hydronic-to-warm air system with domestic hot water preheat. The system consists of the following major components.

o. 3780 square feet flat plate collectors ( 1 cover)

o Collectors assembled in series parallel network

- Water storage ( 1.5 gallons $/ \mathrm{ft}{ }_{\mathrm{c}}^{2}$ )

- Warm air furnace with hot water coil unit

The performance of this system for a Minneapolis multifamily residence is shown in Figures $6.2-1$ and $6.2-2$. The space heating load for a typical year is $721.0 \times 10^{6}$ Btu of which $339 . \times 10^{6}$ Btu or 47 percent is supplied by solar energy. The yearly service hot water load is $38, \times 10^{6}$ Btu of which $23 . \times 10^{6} \mathrm{Btu}$ or 60 percent is supplied by solar.

The operation of the pumps and furnace fan for the system consume $29362 \mathrm{KWH}$ electricity. The auxiliary fuel cost for a gas furnace is $\$ 955$ per year.

The system is applicable to new construction as well as retrofit buildings.

As an alternate, an oil furnace could be installed as an auxiliary. The cost of its operation, based on $40 \xi$ /gallon oil prices, would be approximately $\$ 1364$ per year. If an electric resistance furnace is installed, the auxiliary fuel costs per yeat would be about $\$ 3989$. based on $\$ .0356 / \mathrm{KWH}$.

A heat pump could also be used to supply the auxiliary energy. Assuming the air-to-air heat pump has a seasonal performance factor of 2.5 , the auxiliary energy costs for heating would be $\$ 1595$. per year. 


\subsection{Commercial Building}

The recommended solar assisted heating system for a commercial building is a hydronic-to-warm air system with domestic hot water preheat. The system consists of the following major components:

- 5500 square feet flat plate collectors (1 cover)

- Collectors assembled in series parallel network

- Water storage ( $\left.1.5 \mathrm{gal} / \mathrm{ft}_{\mathrm{c}}^{2}\right)$

- Warm air furnace with hot water coil unit

The performance of this system for a commercial building in Minneapolis is shown in Figures 6.3-1 and 6.3-2. The space heating load for a typical year is $438.0 \times 10^{6}$ Btu of which $352 . \times 10^{6}$ Btu or 80 percent is supplied by solar energy. The yearly service hot water load is $46.3 \times 10^{6}$ Btu of which $41.9 \times 10^{6}$ Btu or 90 percent is supplied by solar.

The operation of the pumps and furnace fan for the system consume $22007 \mathrm{KWH}$ electricity. The auxiliary fuel cost for a gas boiler is $\$ 215$.

This system is applicable to new construction as well as ret rofit buildings.

As an alternate, an oil furnace could be installed as an auxiliary. The cost of its operation, based on $40 c /$ gallon oil prices, would be approximately $\$ 307$ per year: If an electric resistance furnace is installed, the auxiliary fuel costs per year would be about $\$ 899$ based on $\$ .0356 / \mathrm{KWH}$.

A heat pump could also be used to supply the auxiliary energy. Assuming the air-to-air heat pump has a seasonal performance factor of 2.5 , the auxiliary energy costs for heating would be $\$ 360$ per year. 
SELECTED SOIAAR SYSTEN

BTU'S PER DAY AVERAGTI NYFR 30 DAYS






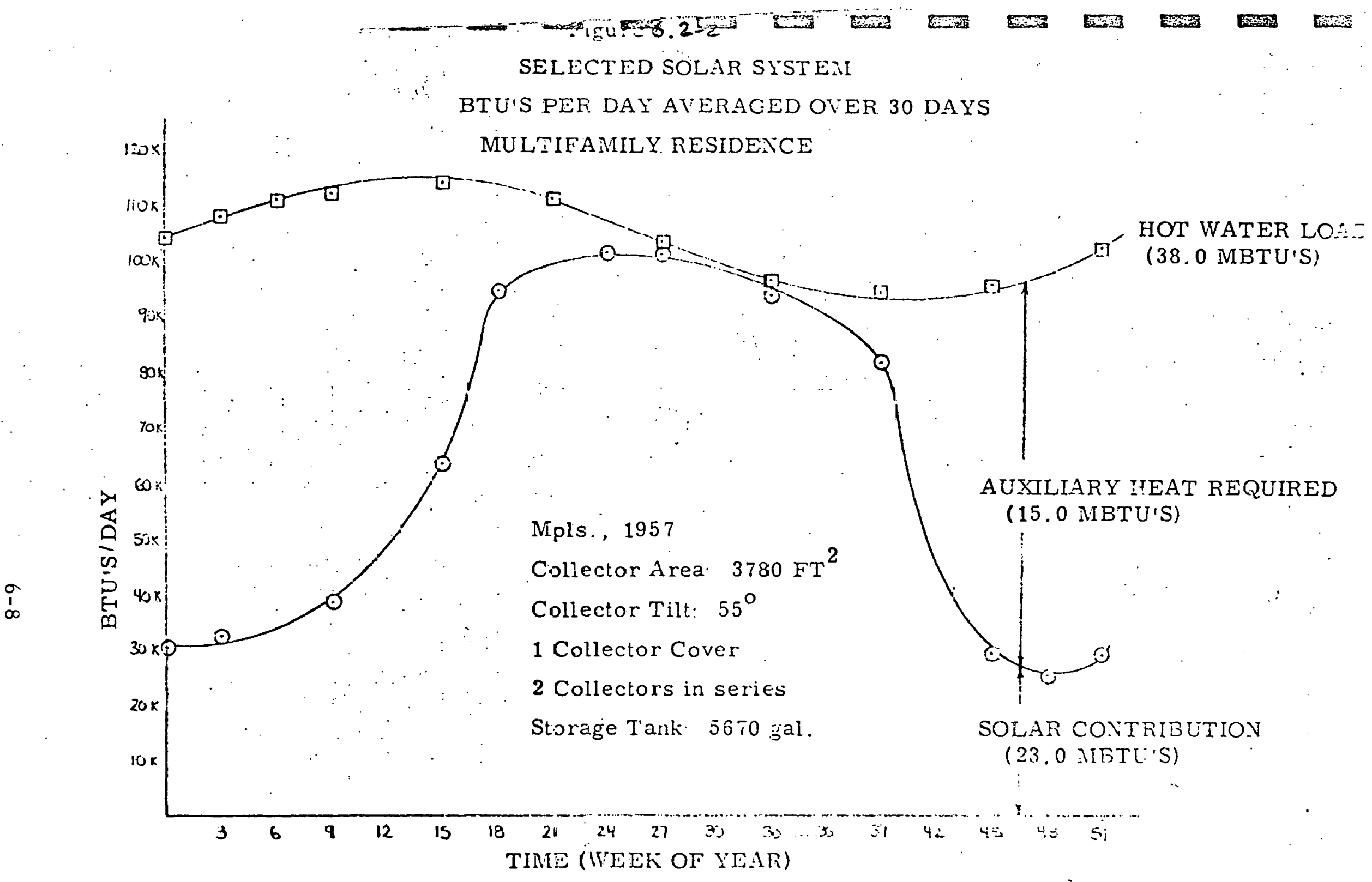




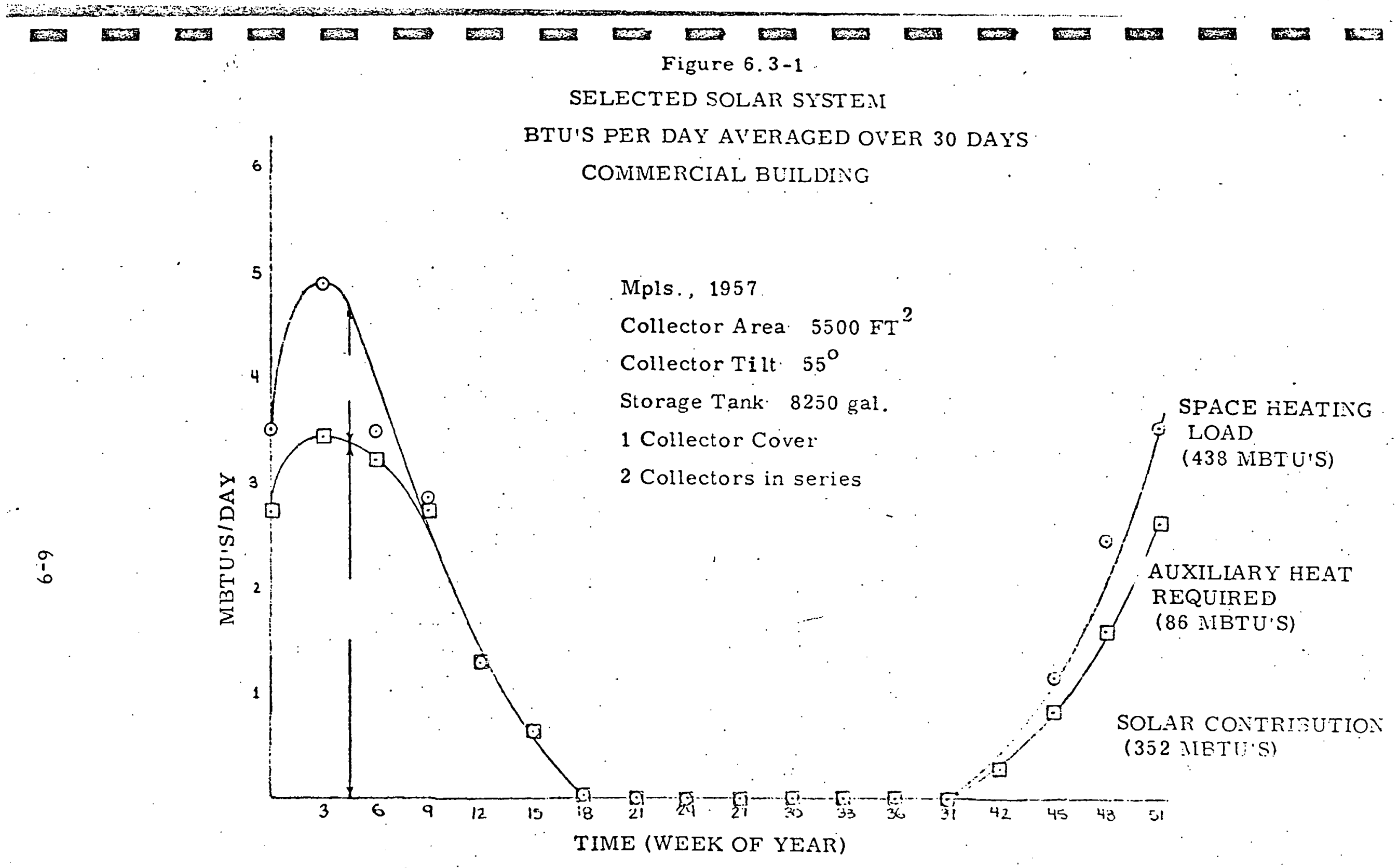



7.0 Design and Development Approaches

\subsection{Int roduction}

Honeywell's approach is to effectively sequence and combine technical efforts to provide the most cost effective prototype system within the schedule guidelines of the statement of work. We have incorporated, as much as possible, subsystems that are "standard" or al ready have bcen proven in similar system applications. This will expedite design maturity and keep system development costs low.

With the similarity of subsystems and the varied degrees of performance maturity, Honeywell has laid out a program that maximizes the effective combination of manufacturing development, qualification, and acceptance efforts. This combining and coordination of efforts is reflected in the overall program schedule which includes as parallel effort, the development of residential, multifamily and commercial systems.

The Development Plan (DR 500 Item 1) summarizes the approach, detailed plans for developing the subsystems and a plan for system installation and evaluation.

\subsection{Detail Design Procedure}

Following the selection of specific sites, the subsystem designs will be completed for cach system. These detailed designs begin with a systematic study of the Interim Performance Criteria and codes and standards for application to the particular subsystem being designed. Next, the particular design iasks which assure compliance with the criteria are completed. Consideration during design is given to modularity, retrofit versus new construction, utilization of off-the-shelf components and designing for a 
wide variety of subsystem sizes. Upon completion of the subsystem designs and the subsystem integration tasks, the heating systems will be complete to the extent that the drawings and specifications will form a completed design package.

7.3 Interim Performance Criteria and Standards

The Interim Performance Criteria for solar heating and combined heating $/$ cooling were developed to provide a baseline design criteria for the large number of solar applications being developed at the present time. These criteria will be used to:

- Assure minimum levels of health and safety consistent with similar standards for conventional systems.

- Ensure consistent performance over time.

- Verify that design performance levels will be met.

- Ascertain that systems will be durable, reliable, maintainable and conform to good engineering practice.

The IPC will not be used to take the place of existing standards of good engineering practice or to supplant local or national codes or test and material specifications. The IPC will be used as a framework for applying these codes and standards to solar system design.

Honeywell has used the framework provided by the IPC to consolidate the design standards shown in Table 7-1 to be used in developing solar systems.

Good engineering practice will be guided by the extensive ASHRAE Handbooks. The Handbook of Fundamentals will be used for guidance in material data, psychrometrics, weather data and methodology of heat load calculations. The Systems Handbook can be utilized for design information 
Table 7-1

APPLICABLE DESIGN ST ANDARDS AND SYMIOLLOGY

Reference

ASHRAE Handbook, Fundamentals, 1972

ASHRAE Handbook, Systems, 1973

ASHRAE Handbook, Applications, 1974

ASHRAE Equipment Guide and Data Book, 1972

National Plumbing Code, ASA, A 40.8

HUD Minimum Property 'Standards

4900.1 Single Family

4910.1 Multi Family

4930.1 Acceptable Practices

ANSI A58.1 1972 Building Code Requirements for Minimum Design Loads in Buildings and other Structures

Uniform Building Code, International Conference of Building Officials, 1973

NBS, Building Science Series 23, 1969

NFPA, National Electric Code

NFPA No. $89 \mathrm{M}$

NFPA No. $90 \mathrm{~B}$

Fire

NFPA No. 211

Standards

NFPA No. 54

NPPA No. 101

Public Hcalth Scrvice Drinking Water

Standards, HEW, 1962
Hail Resistance

Electrical Installation

\section{Application}

System Performance

(H, HC)

System Performance (DIIW) :

Plumbing

Residential System Installation and Structural

Commercial

Structural

Structural

Installation

HW Subsystem 
on ducting systems, hydronic system principles, water heaters, heat pumps and systems testing while Applications Handbook can provide solar system guidelines.

The mandatory codes which will be studied and utilized fall into three categories. First the structural codes which dictate structural form and integrity. An example is the HUD Minimum Property Standards which is applicable to Residential and Multifamily installations and deals with structural and asthetic values. It is primarily applicable to roof mounted collectors. The Uniform Building Code is more detailed in mechanical installations and is applicable to both Residential and Commercial structures. The second category of codes covers the installation of mechanical systems. Two examples are the National Electric Code and the National Plumbing Code. The NFPA National Electric Code has gained national acceptance at this time. In 1975; it became an ANSI standard, ANSI C1 - 1975 and it will be used in all installation designs. The National Plumbing Code, on the other hand, has not gained universal acceptance. The closest thing to a national code is the American Standards Association ASA A40.8 Code sponsored by ASME. Accordingly, ASA A40.8 will be used as a guide but local codes peculiar to the site selected will also be checked for compliance.

A third category of codes are the health and safety codes. The National Fire Protection Association has a number of codes influencing the design of hot water heaters, auxiliary healing, high temperature solur equipment, electric motors and controls. In addition, the integrity of potable water will be protected. The guidelines for potable water standards will be taken from HEW Department of Public Health. 
As opposed to mandatory controls, there will be the need to draw on standards that affect material selection for the purposes of efficient selection. It is expected that extensive use will be made of material specifications developed by the American Society of Testing of Materials. These same sources will be used whenever appropriate to design tests of materials and components for the sake of standardization. Where appropriate standard tests do not exist, test procedures will be developed.

\subsection{Design. Procedures - Collector Subsystem}

The collector subsystem is an example of the design procedures to be used on subsystem design and/or development. This product is presently being manufactured by Lennox Industries and is considered developed to the prototype level. However, collector qualification was not complete. A study of applicable IPC was made of those tasks already accomplished to determine what parameters of the solar collector had been sufficiently investigated already. In the case of the collector, the development activity fell into two main areas: function and mechanical configuration.

During collector development, much effort was expended to design a highly efficient collector. Selective coatings and glass transmittance were investigated thoroughly. Therefore, it was determined that the efficiency of collection was a fixed design characteristic at the beginning of qualification and that efficiency of a newly produced collector was not a relevant qualification criteria. At the same time, however, it was apparent that the affect on efficiency of environmental exposure over time had not been sufficiently investigated so efficiency degradation was determined to be a qualification criteria. 
The mechanical configuration of the collector was investigated during development yielding a design that permitted easy integration with the structure and a long service life. On element of the mechanical configuration which was not verified during development was exposure to mechanical loads inherent in a structural application.

The result of reviewing the work done during development was a determination that the following tests needed to be conducted to complete qualifications of the collector:

Degradation due to:

Solar Exposure

Pollutants

Thérmal Exposure

Outgassing.

Mechanical loads due to:

Internal Pressure.

Roof Loads

Irall

After determination of the parameters to be tested, an investigation was made to find or develop suitable test techniques. Wherever feasible, the approach was to make use of existing standard test techniques. Toward this end, the Interim Performance Criteria was used as a baseline to standardize the tests. Referenced test standards were used whenever practical. This approach resulted in a series of tests set out in the following paragraphs. 
Efficiency tests which will establish a baseline for determining the extent of any degradation due to environmental exposure were designed around a solar simulator. This was done to permit control and consistency of solar nux which is the most important variable in the test. There is not a standard acceptable test for testing with a solar simulator. The standard test sponsored by the National Jurcau of Standards is based on natural sunlight for flux. Because of this, a new procedure was developed using the methodology of the NBS, hitt substituting the solar simulator for a nux source.

The effects of internal pressure is accomplished by a simple hydrostatic test of the collector pressurized to 150 . percent of its rated pressure.

The effect of normal roof loads will be done by determining a uniform load criteria based on standards contained in the HUD Minimum Property Standards. This criteria will be demonst rated by uniformly placing sandbags on the normally supported collector.

The effect of hail on roofing materials is determined by an NBS specification involving propelling a spherical ice ball into the material using a compressed air gun. This procedure will be used without deviation. Collector glass will be considered a roofing material.

The effect of solar flux over an extended time period will be tested in accordance with one of the options in the IPC. Namely, a six month exposure in an area near Phoenix, Arizona where the mean daily solar flux exceeds 500 Langleys. The efficiency of the collector will be measured before and after this exposure to determine if any degradation has occurred. 
The effect of airborne pollutants will be determined by exposing coupon specimens of collector parts to ozone, salt, sulfurous acid, hydrocloric acid, and nitric acid. The exposure will be in accordance with IPC standards and any degradation will be determined by using AST M materials examination techniques.

The effect of the thermal environment will similarly be done using coupon specimens exposed to temperature extremes in environmental chambers. Examination of the coupons will be in accordance with ASTM procedures.

Outgassing of collector insulation will cause a degradation of transmittance of the collector glass. This will be tested by measuring transmittance by ASTM methods both before and after exposure to solar fiux.

Upon completion of these qualification tests, the collector should meet all applicable IPC and standards. Details of the application IPC and the qualification tests procedures are contained in the Verification Plan (DR 500 Item 2), and the Qualification Tests for Collector Subsystem (DR 500 Item 13).

In addition, it was recognized that the collectors are modular, suitable for retrofit or new construction and can be combined to provide any subsystem size. It was also recognized that a study of possible flow configurations for various collector arrays should be studied. Of concern is the possibility of non-uniform flow in the collector arrays which can lead to serious degradation of performance. A simulation program was developed from which guidelines will be established for the number and methods of collector arrangements on the supply and return headers in an array. The results of this study will be presented at the Preliminary Design Review. 
8.0 Special Data for Healing Systems
Preliminary Design Review

This section contains the information requested by $A$ ppendix $B$

para $4.1 .3 \mathrm{~d}, \mathrm{e}, \mathrm{g}$ and $\mathrm{h}$ that is to be included with the data submitted two weeks prior to the Preliminary Design Review.

It includes: 8.1 Hazard Analysis

8.2 Drawing List

8.3 Type I and II Documents

8.4 Prototype Design Review Data Recommendations

8.5 Site Data Acquisition System Schedule

8.6 Symbols

3

8

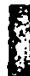

9

(1)

in

3 


\subsection{Hazard Analysis}

This section consists of a copy of the Hazard Analysis submitted 9 September 19.76. This preliminary analysis will be updated at the Prototype Design Review. 
Document F3437-P-103

9 September, 1976

HEATING SYSTEMS

HAZARD ANALYSIS

\author{
DR500 Item 18 \\ Contract NAS8-32093
}

Honeywell Inc.

Energy Resources Center

2600 Ridgway Parkway N. E.

Minneapolis, Minnesota 44513 
Document $F 343_{i} \cdots+103$

9 September, 1976

HEATING SYSTEMS

HAZARD ANALYSIS

DR500 Item 18

\begin{tabular}{|c|c|c|}
\hline & Signatures & Date: \\
\hline Prepared by & 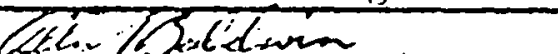 & (lex 251915 \\
\hline Approved by & \& thereedp & $i i x=1,-90$ \\
\hline & $x(-1.0)$ & (..) $+1 ! 10.1$ \\
\hline kreviewed by & Doth $C K_{x}$ & $2 x_{1}=720$ \\
\hline
\end{tabular}

Revisions

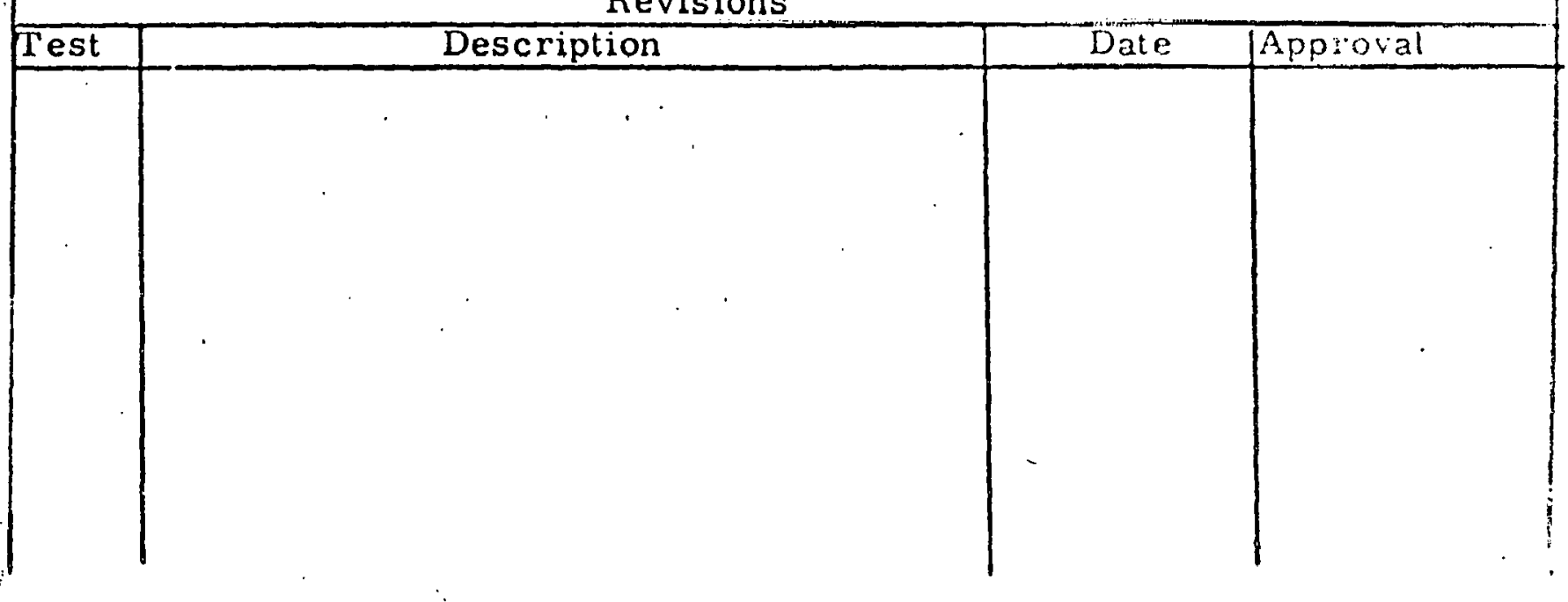




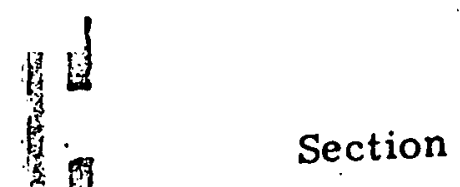

1. 0 INTRODUCTION

2. 0 DICTIONARY

3.0

4.0

\section{CONTENTS}

Page

$8-6$

$8 \cdot 6$

$8-8$

$8-8$ 


\subsection{INTRODUCTION}

This document has a twofold purpose:

- To identify and categorize actual or potential hazards or hazardous conditions in single-family, multiple-family, and commercial solar, heating systems.

- To identify, rationalizc, and document meacures to eliminate or mitigate these hazards.

These precautionary activities will continue through system developrnent, and this document will be revised as necessary to ensure its completeness prior to the heating systems Prototype Design Review. All revisions will be approved by the program manager and will be recorded in the revision $\log$.

\subsection{DICTIONARY}

Hazard - A hazard is any actual or potential condition that could cause injury or death to persons, or damage to or loss of equipment or property.

Hazard Level - A qualitative categorization of hazards in terms of potential consequences.

The following hazard levels which pertain in this program result from conditions such that user error, environment, design characteristics, procedural deficiencies, or component or subsystem failure could cause these types of damage:

$$
\begin{aligned}
\text { Category I - Negligible - Will not result in injury to persoris } \\
\text { or damage to the system. }
\end{aligned}
$$


Category II - Marginal - Can, if not controlled, result in minor injury to persons or damage to equipment or structures.

Category III - Critical - Can if not controlled, result in serious injury to persons or major damage to equipment or structures.

Category IV - Catastrophic - Can, if not controlled cause death to persons or destruction of equipment or structures.

Hazard Control - Actions that eliminate or mitigate hazards. The hazard control techniques below are in descending order of preference. The highest level of practical action will be taken in a given case, with the goal in all cases being to reduce the hazard to the Category I level, or below, i. e., minimize it even further.

(1) Design for Minimum Hazard - The major effort during the design phases will be directed toward selecting appropriate design safety features, e.g. , failsafe, redundancy.

(2) Safety Devices - Known hazards that cannot be eliminated from the design will be reduced to an acceptable level through use of appropriate safety devices.

(3) Warning Devices - When it is not practical to preclude the existence or occurrence of an identified hazard, a device that will detect it and provide timely warning will be used.

(4) Special Procedures - When none of the above is feasible, special operating procedures will be developed to reduce the hazards. 


\section{0 IDENTIFICATION AND CONTROL OF HAZARDS}

This process will, as stated, be continuous during system development, with the goal being to reduce all hazards to the Category I level or below.

Table 1 is a list of identified hazards, the levels to which they are hazards, elements exposed to them [persons (p), equipment (e), and structures (s)], and corrective actions to eliminate or minimize them.

\section{0 RATIONALE FOR CORRECTIVE ACTION}

Class (2), (3) and (4) corrective actions leave residual hazard potential associated with failure of a safety device, failure of or failure to heed a warning device, or failure to follow procedures properly. The rationale for accepting this residual hazard rather than striving for a fail-safe design in all of its aspects is set forth below.

(Will be provided in a future revision). 
Table 1. Hazards and Corrective Action

西

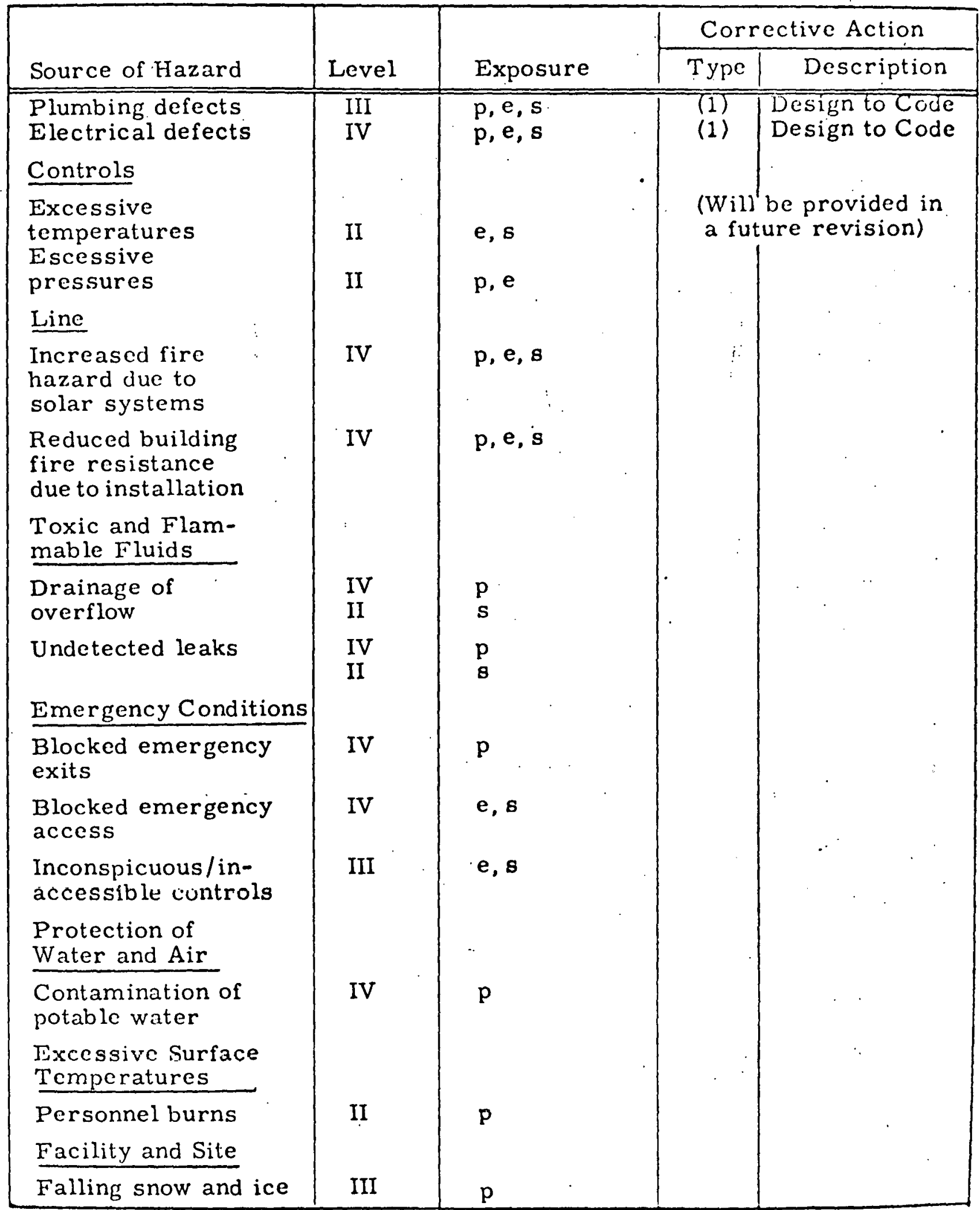


8.2 Drawing List

The attached chart outlines the drawings required to define each of. heating and heating/cooling systems. To date, only top level schematics and a reference to the appropriate appendix of the System Specification SK 140021 are shown as being completed. As the site specific design is accomplished - an installation drawing will be created and identified for each system and assembly drawings prepared for each subsystem. 


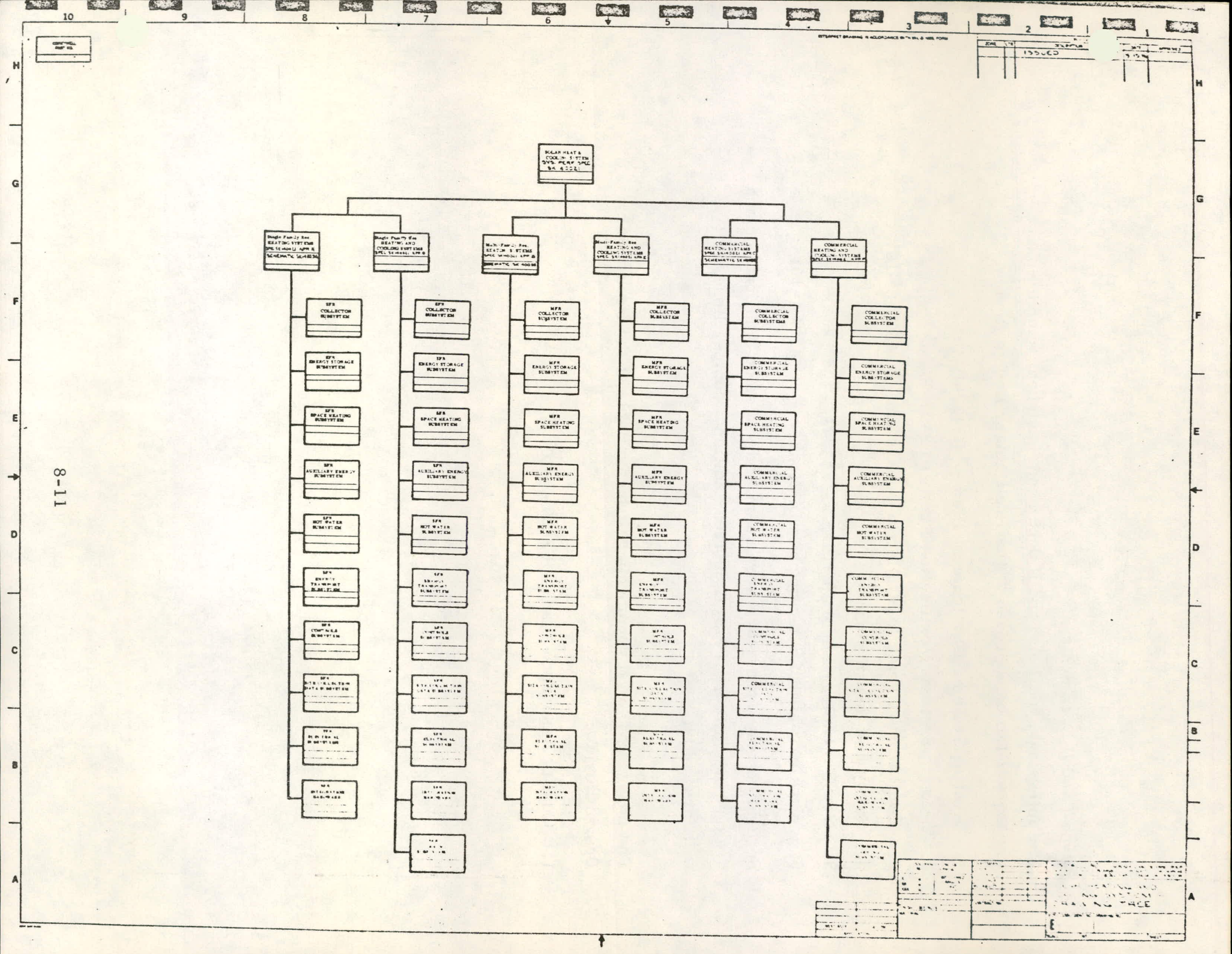


8.3 Type I and II Documents

The following Type. I or Type II documents have been submitted and are expected to be approved at the Preliminary Design Review.

1. Heating Systems Development Plan - F3437-P-101

2. Heating Systems Verification Plan - - F3437-P-102

3. Qualification Tests for Collector Subsystem -- F3437-T-101

4. Safety and Health Plan =-

5. New Technology Reporting Plan -- F3437-P-104

6. Work Breakdown Structure and Dictionary -- F3437-A-101

Several copies of the above were submitted and so no additional copies are now submitted. If MSFC desires additional copies, Honeywell will forward them.

The following Type II documents will be available at the Preliminary Design Review.

1. Quality Assurance Plan -- F3437-Q-101 


\subsection{Prototype Design Review Datà}

The data Honeywell recommends to be used to accomplish the Prototype Design Review is as follows:

- System Specifications for SF, MF, and Commercial

- Installation drawings for each site

- System top assembly drawing or bill of material with site specific callouts

- Subsystem assembly drawing or bill of material with site specific callouts

- Procurement Specifications

- Verification data and status summary

- Final Hazard Analysis.

- List of special handling, installation and maintenance tools

- Review of support philosophy and spare parts requirements

- Proposed format and outlines for installation, operation and maintenance manuals

- Other Type I, II and III documentation

- Results of analysis and trade-off studies 


\subsection{Site Data Acquisition Subsystem Schedule}

The sensors furnished by MSFC as part of the Site Data Acquisition Subsystem will be required for the Heating Subsystcms as listed bclow. These dates are based on the key assumption that the sitc ready date and the contractual delivery date of $11 / 15 / 77$ are approximately coincident. Any significant change in this relationship will alter these dates. HI assumes the balance of the data Acquisition Subsystem to be available (on-site) at site ready date.

Subsystem

Single Family Residentiál

Multi Family Residential

Commercial Applications
Sensor Necd Date

19 May 1977

19 May 1977

24 May 1977 


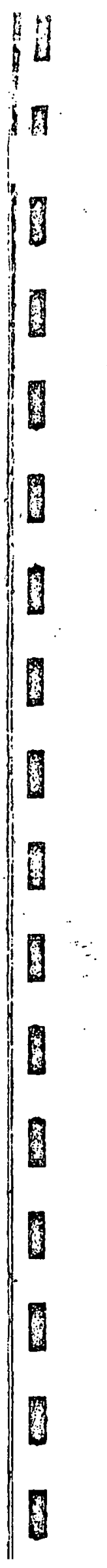

Section 8.6 Symbology -

Honeywell is planning to utilize the ASHRAE abbreviations and symbols as the basis for the III standard for abbreviations and symbols. A copy of the $\triangle$ SHRAI standards is included herein for completeness, i. e., Chapter 28 of Handbook of Fundamentals 


\title{
ABBREVIATIONS AND SYMBOLS
}

\author{
Standard Abbreviations, Leffer Symbols, Grophical Symbols for Piping, Ductwork, Heating and Ventilating, Refrigerating, \\ Identificalion of Piping by Color
}

$T$ IIIIS chapter contains information regarding abbreviations and symbols which are oi particular interest to the ongineer engaged in heating, veulilsting, refrigeratung, and air conditioning.

\section{ABBREVIATIIONS FOR TEXT AND DRAWINGS}

Abbreviations are shortened forms of aames and expressions employed in texts and tabulations. and should not gencrolly be used as symbols in equations. Most of the following abbrevintions have been compiled from a list oi approved standards.1.2.2 In general, the period has been omitted in all abbreviations. except where the omission results in the formation of an English word.

\begin{tabular}{|c|c|c|}
\hline Term & Toxt & Drowings \\
\hline 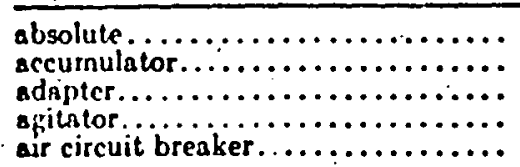 & $\begin{array}{l}\text { abs } \\
\ldots \\
\cdots \\
\cdots \\
\cdots\end{array}$ & $\begin{array}{l}\text { ABS } \\
\text { ACCUM } \\
\text { ADPT } \\
\text { AGTR } \\
\text { ACB }\end{array}$ \\
\hline
\end{tabular}

air condition

(-ing, -eil, er)

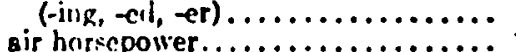

Girm horspower................

glteration.....................

alicroating current.............. ac

shp

AIR COND

.. AL.II

ALTS

altitude. ........................

ambirnt....................

Americun Standard.................

Amrriran wire gage..............

amprern..................

amperr-hnur...............

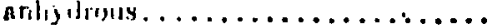

Anjstrom unit.......................

npparulus dew point. . . . . . . .....

agurtment. ..................

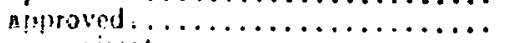

ai!irnximate...............

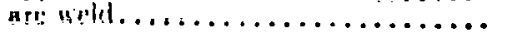

atnosphere................

nutonistir..................

antomatic rheck valve.............

aviren $\ldots \ldots \ldots \ldots \ldots \ldots \ldots$

svoirulumig.................

\section{ALT}

mb AIIB

Amer Std AiIER STIJ

AllG AllG

amp A.IP

amp-hr A.IIP.HR

AIHYD

A

adp ADP

.. APT

.. APPD

anpme APPROX

ARC $/ W$

atm ATII

... AUTU.

$\ldots \quad$ ACV

avg AYG

avip AYDP

Marnneter................. baro BAR()

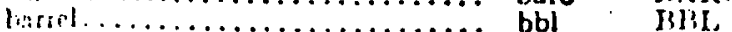

lingintent .......... Birt

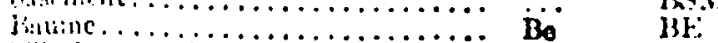

bill of mulerial. ................

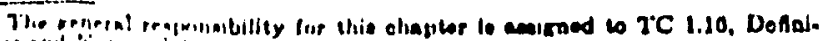

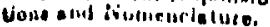

\begin{tabular}{|c|c|c|}
\hline Term & Toxf & Drowings \\
\hline 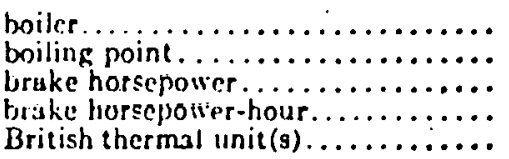 & 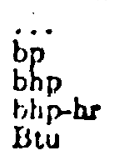 & $\begin{array}{l}\text { BLR } \\
\text { BPP } \\
\text { BIIP } \\
\text { BHP-HR } \\
\text { BTU }\end{array}$ \\
\hline
\end{tabular}

British thermal unire per hour...... Btub BTUH British ther hital mitg

per hour (thousandg) .............

Bromn \& Sharpe wire gage...........

bughel..$\ldots \ldots \ldots \ldots \ldots \ldots \ldots \ldots$.

B-X cable..................

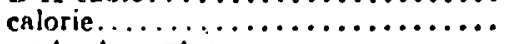
center-to-center................

centigrade heat unit............. centigram....................

centimeter................. cm centimeter-gram-second (system)... Cg

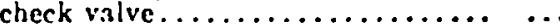

clorkwise. ....................

condenser......................

IIBH

B\&S B\&S

bu $\quad \ldots$

$\therefore \quad B X$

cal CAL

c to c C to C

cg $\ddot{\text { CG }}$

corporation..................

counterclock wise...............

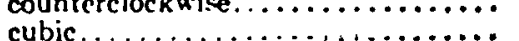

cubio ecntimeter................

cubic fect per minute..........: :

cubic lect per second. ..............

cubic foot....................

cubic inch....................

cylinder .....................

deribel.

ingrese...........................

degree Centigrade...............

degree Fnhronheit. ..............

degrec kiplvin.................

degree Rankine................

dew point tempersture........... dpe

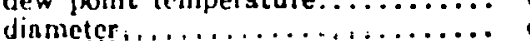

direct connected...............

direct current................ de

discharge ..................

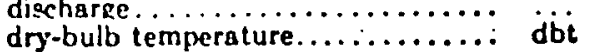

\section{C.M \\ CGS \\ CV}

CIV

COND

conp

CCW

ou

CC

cim CFII

cfo CFS

ruft CU FT

cu in CU is:

cyl CYL

\begin{tabular}{|c|c|}
\hline $\begin{array}{l}\mathrm{db} \\
\mathrm{deg} \text { ir } \\
\mathrm{C} \\
\mathbf{F} \\
\mathbf{K}\end{array}$ & $\begin{array}{l}\text { DB } \\
\text { DEG or } \\
\text { C } \\
F \\
K\end{array}$ \\
\hline$\underset{d p t}{\mathbf{R}}$ & $\begin{array}{l}R \\
D M T \\
D \text { I } \\
\text { D.R.CONN } \\
\text { DC }\end{array}$ \\
\hline
\end{tabular}

DISCH

TAhbreviations for Seientife ood Engineering Terms. 210.1-i9t) (A.geneas National Stanidards Instilu'e." Standards Inalitutel.

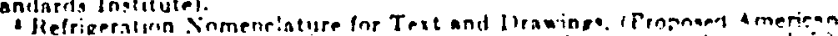

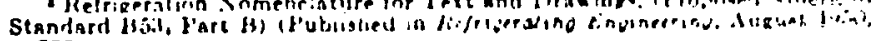

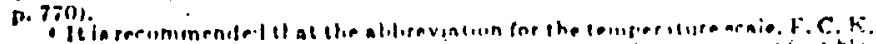

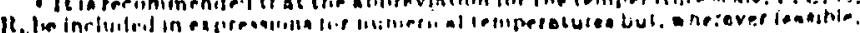

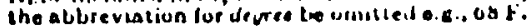




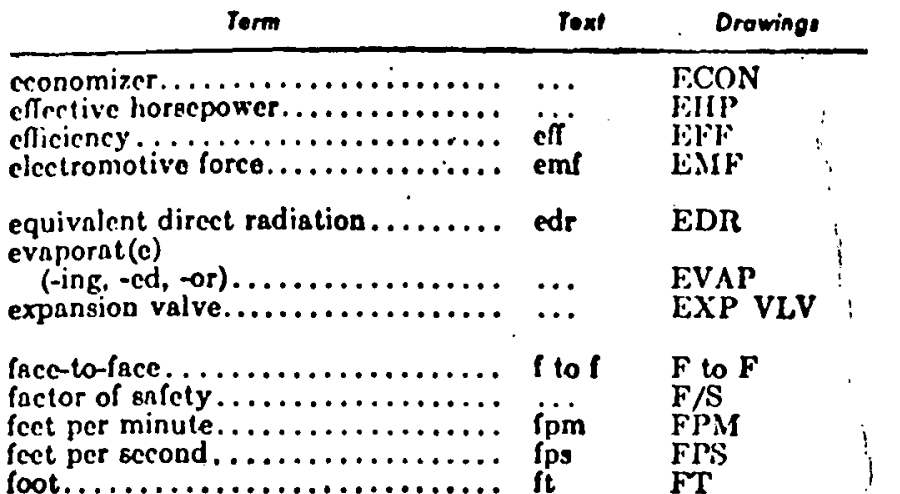

foot pound.................. ft ft lb FT LB foot-pound-sccond (system) ........ frecring point. ................ gnge or gauge. ................ gallon.................... gal

FPS

FP

GA

gallons per hour.............. gph GPH

gallons ner minute. ..............

gallone per second..............

grain.......................

GPMI
GPS

higher herting value............. horsepower.................. borsepower-hour............... hour..................... inch

inch-pound ................ indicnted horsepower............. indicated horscpower-hour........ inside dinmeter................ iron-pipe size................

kilocnlorie. ................ kilogram..................

kilowntt...................

kilowatt hour.......................

linear feet.

liquid $\ldots \ldots \ldots \ldots \ldots \ldots \ldots \ldots \ldots$ lognrithm (natural) ............. logarithm (to base 10)........... lower henting value.............. maintenance. ..................

male and female............... mapq....................... msximum................... menn effectivo................. melting point..................

meter.................... metere per second................ mirron....................... milrs per hour................. milinchcs....................

millimeter..................... minute................... minimum................... molecular weight. ...............

mol......................

Nntional Electrical Code...........

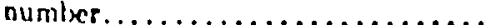

ounce........................

outride dinmrler...................

ports per million...............

pound...$\ldots \ldots \ldots \ldots \ldots \ldots$.

mund per aquines foot. ...........

poundw per supuare font absolute....

poundy lier actuare foot gugo........

pounda per square inch............

gpm
gps
spell out
gcal

GंCAL

hisv iif

hphr HPHR

in. IN.

in.-lh , IN.-LB

ihp IHP

inph IIIPH

ID ID

kesl $\dot{\mathrm{kg}}$

kw $\quad \mathrm{KW}$

kwh KIVII

lin $\mathrm{ft}$

$\operatorname{lin}_{\log } \quad \mathrm{LIQ}$

$\log _{10} \quad \cdots$

LHV MAINT

M\&F

mas MASS

$\max M A X$

mep MEP

mp MP

m $\quad M$

mpe MPS

$\cdots \quad$ U(MU)

$\mathrm{mph} \quad \mathrm{MPH}$

mi MI

mm MII

$\min \quad M I N$

$\min \quad M I N$

mol wt NOL WT

mol MOL

... NFC

no. NO.

$\begin{array}{ll}\text { oz } & \mathrm{OZ} \\ \mathrm{OD} & \mathrm{OI}\end{array}$

ppm PPM

Ib LB

pofa PSFA

prfa PSFG

pa PSI
Torm

pounds per aquner inch ulisolute... pound pere square inch gage.......

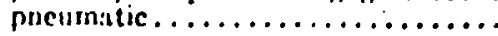
pressure....................

pressure reducing valve...........

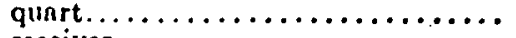
recciver..................... recirculate(d) ...............

relntive humidity revolution.................. revolutions per minute........... revolutions per second...........

Saybolt seconds Furol (oil viscosity). Savbolt seconds

Universal (oil viscosity) ..........

sccond ......................

shaft horscpower.............

epccification................

epccifio gravity................

spccific heat.................

squarc............................

squnre foot....................

square inch $. . \ldots \ldots \ldots \ldots \ldots \ldots . .$.

standard.$\ldots \ldots \ldots \ldots \ldots \ldots \ldots$

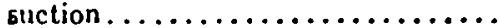

tempcrature................

thermostat.................

thousnnd ...................

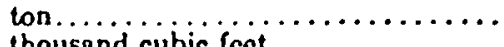

thousand cubic fect..............

ton of refrigeration..............

United States Guge................

United States Standard . . . . . . . .

vacuum..................

valve......................

vapor proof . ................

velocity........................

viscosity.................. vis

volume...................

hatt. ......................

watthour ....................

net-bulb temperature . . . . . . . .

reat

Drowinge

pais PaIA

paig bifl;

PNEU

press. SRlEss.

... PRV

at QT

... IRECIRC

rh IRH

.. REQD

ipon RPM

Ko KPS

SSF SSF

SSU SSU

Bec SFC

shp SHP

.. SPEC

p $R \quad S P G R$

ap bt SP HT

B $S Q$

it $\quad \cdots$

oq in. STiD

.. SUCT

. THERMO

Mi

spell out ijCF

is $\quad$ TR

is3 USS

.. VAC

$\ldots v \quad V$

VAP PRO

VE.L

VISC

VOL

IV

WHR

WBT

yesr. . . . . . . . . . . . . . . .

YK

\section{LETTER SYMBOLS5.8}

1. Letler Symbol. A letter symbol is a single character, such as $t$ for temperature, with subscript or superscript if required, such as $t^{\prime}$ for temperature of saturated liquid, used to designate a physical magnitude in mathematical equations and expressions. Two or more symbols together alarays represent a product.

Letter symbols are to be distineuished from abbrevintions, mathematical signs and operators, graphical symbols and chemical symbols.

2. The Same Symbols should be used for the same physical magnitude regardless of the units employed and recardless of epecial values occurring for different states. points, parts, times, etc. Linits or special values may be distinguished when necessary by subscripts, superseripts, or by upper- and lower-

- Lettar Symbola for Qunntitien uned in Mechanien of Solirl Bndire. Y10.3-

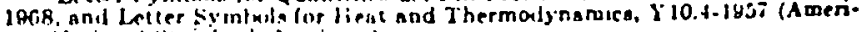
can National sturiatrils Inntitu(r).

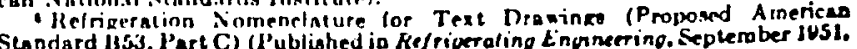
p. B76). 
case letters when both are specifically includer as syminla in a otandard list. The units used should be indicated when necessary. Sometimes different symbols are used for the components of a vector.

3. Subscript. A sulseript preferably should be a single character. It is commonly employed to indicate constancy of a particular physical magnitude, such as pressure or temperature, when there are other variables. A nultiple subeript, sometimes divided by a comma, refers to more than one state, point, part, tinie, etc. A subscript should not be attached to a subseript.

4. Supcrscript. A symbol with a superscript, such as a prime (") or a second ("), should be enclosed in parentheses, braces, or brackets before affixing an exponent-e.g.$\left(D^{\prime}\right)^{2}$. A complicated exponent (or any other expression frequently repented) may be replaced by a single symbol selected to represent it. Reference marks should not be attached to symbols.

5. Unlisted Magniludes. To symbolize a special value of a listed magnitude, sec Item 4 . The symbol chosen by an author for a physical magnitule not appearing in any standard list should be one that does not already have a different meaning in the ficld of the text.

6. When standard symbols in related fields are needed, reference to AXSI standards is recoinmended:

Ietter Symbols for Heat and Thermodynamics, ANS Yil-1957

Letter Symbols for Hydraulies, ANS Y10.2-1058

Ietter Symbols for Chemical Engineering, ANS Y10.121055

Ietter Symbols for Quantities used in Mechanics of Solid IBoxlics, A.NS 710.3-19\%

- Letter Symbols for 1'hýsics. ANS Z10.6-1948

Additional symbols and variations in the standard symbols found necesiary in the individual chapters will be found in lists at the end of Chapters $1,2,3,4,5$, and 22 .

\section{IETTER SYMBOIS}

\begin{tabular}{|c|c|c|}
\hline Symbal & Deteription of ilem & Trpicọl unils \\
\hline 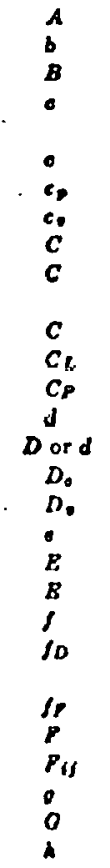 & 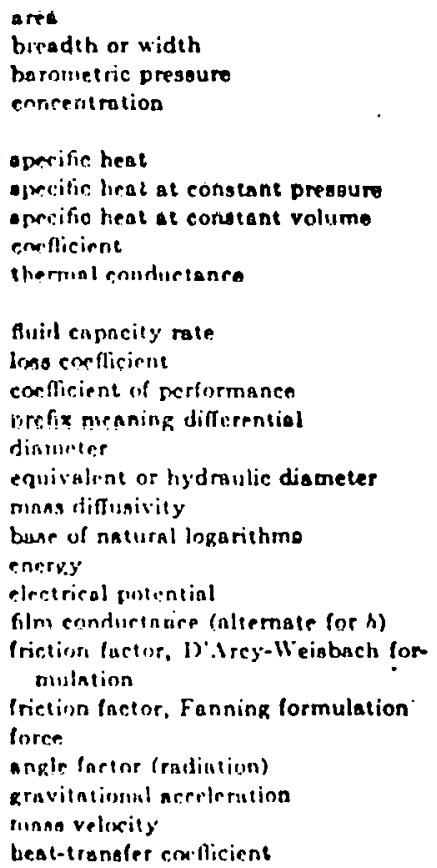 & 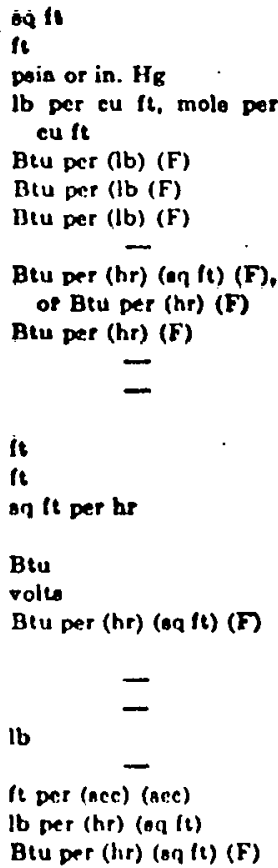 \\
\hline
\end{tabular}

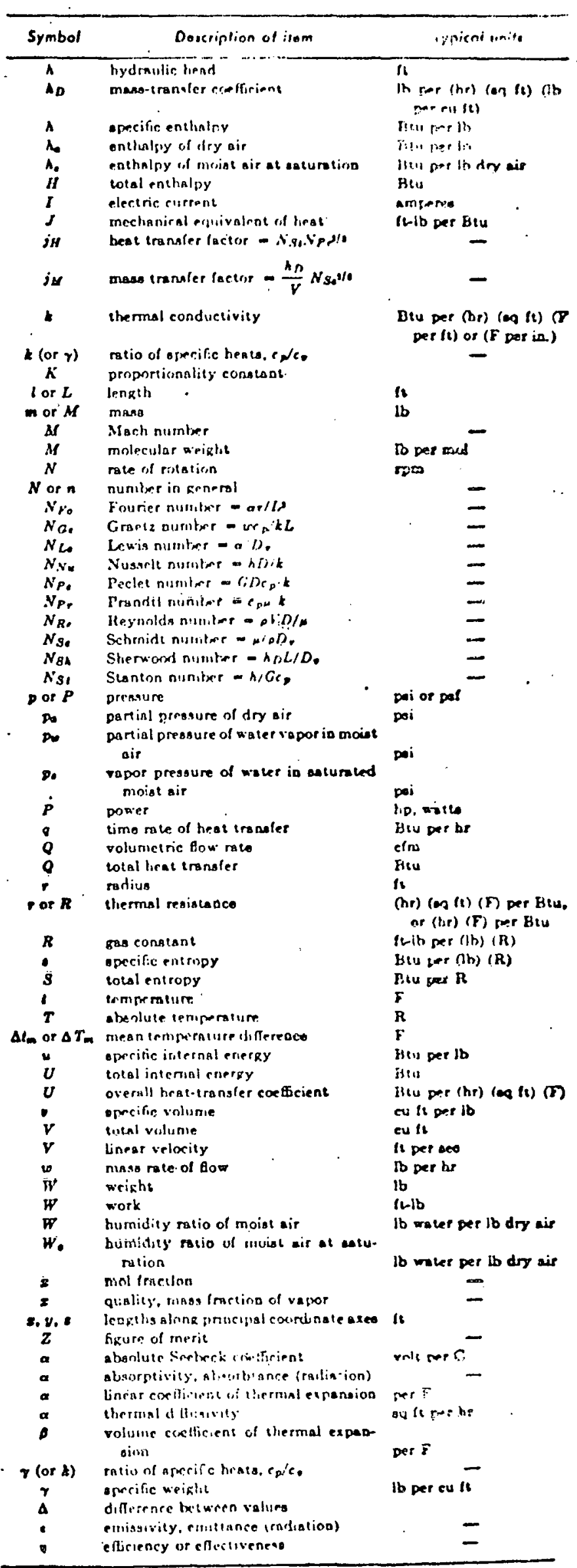




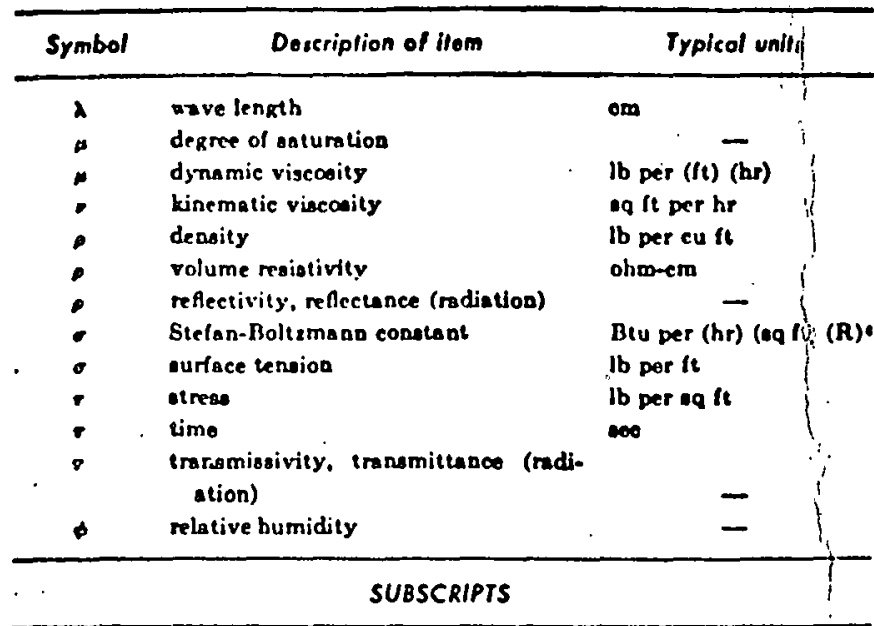

These are to be affixed to the appropriate aymbolo. Several nubseripta'may be used together to denute conibinations of various atates, poince, or patha. Orten the oubecript indicates that a partieular property is to be kept conatant in - proceras.

a,b, - referring to different phascs, statce or phyaical conditione of a oubalarre, or to different oubotances

- oir

- ambieot

b barometric (preasure)

c referring to critical atate or critical value

c convection

do dry bulb

dp dew point

- base of astural logarithms

$f$ releming to salurated liquid

$f$ film

fo relerring to evaporation or condensation

$P$ Iriction

- referring to osturated vapor

a referring to a process having no change in enthalpy

$H$ waker vapor

i reterring to esturated solid

- incernal

if referring tc change of phase in melting

ig relerring to change of phase in aublimstion

- kinetio

$L$ latent

w mean value

Af molar bauio

- referring to initial or otandard states or cu iditions

$p$ neferring to constsnt presaune conditions or proceseses

- Dotential

- refrigerabs

v radient or radiation

- referriog to moist air al saturation

- sensible

- moforina to isentropie conditiviei ui prucesecs

- static (preasure)

- ourlace

- Tolal (presoure)

$\boldsymbol{T}$ referring to isothermal conditione of processes

- veferring to conatant volume conditions or procecenes

- vapor

- velocity (preanum)

- und

- wacor

not net bulb

1,2, - different pointo in a procese, or different instente of timo

\section{GRAPHICAL SYMBOLS FOR DRAWINGS"}

\section{Piping}

Hooling

IIigh-Pressure Stenm

Medium-Pressure Stenm

Low-Pressure Sicam

High-Pressure Retum

Medium-l'ressure Return

Low-Pressure Return

Boiler Blow On

Condensate or Vacuum

Pump Discharge

Feedwater Iump Discharge

Makc-Up Water

Air Relief Line

Fuel Oil Flow

Fuel Oil Return

Fuel Oil Tank Vent

Compressed Air

Hot Water !Icating Supply

Ilot Water Heating Returo
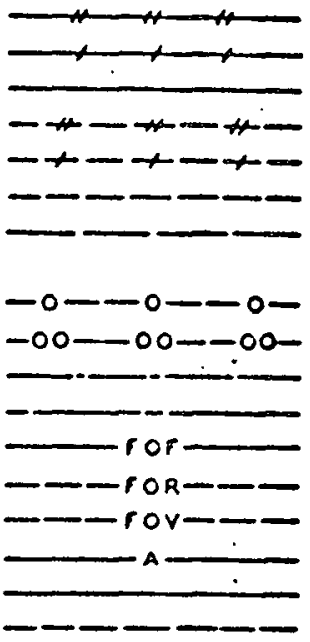

Air Condilioning

Refrigerant Discharge

Refrigerait Suction

Circulating Water Flow

Circulating Wnter Retura

Condenser Water Flow

Condenser Water Returo

Chilled IIater Flow

Chilled Winter Return

Make Up Water

Hlumidification Line

Drain

Brine Supply

Brine Return

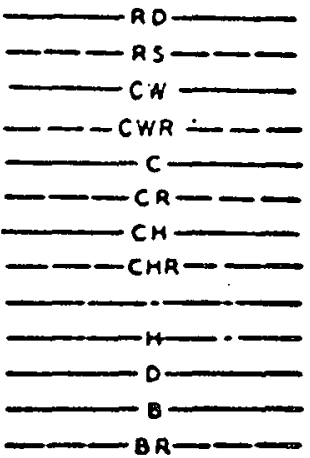

\section{Plumbing}

Soil, Waste, or Leader

(Above Grade)

Soil, Vinstc, or Leader

(Bclow Grade)

Vent

Cold Wnter

Hot Water

IIot liater Return

Fire Lino

Gns

Acid Waste

Drinking Viater Flow

Drinking Water Return

Vucuum Cleaning

Compressed Ais.

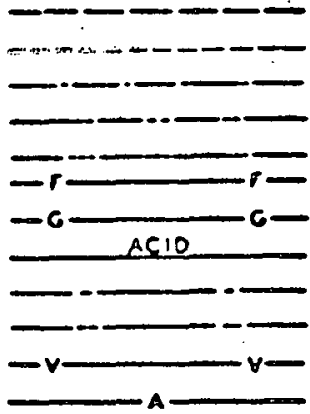

Sprinklere

Main Supplics

Branch and IIead

Drain

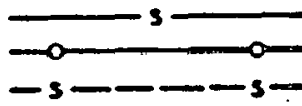

Volves

\section{Check Valve}

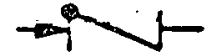

IExtrected Irom: Amprican National Sianderd Granhical symbolo for Pine

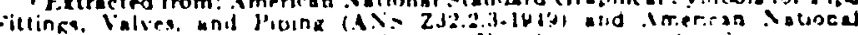

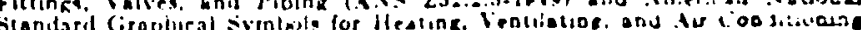

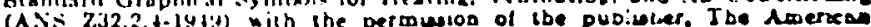

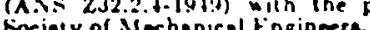




\section{Aoglecheck Valvo \\ stoṕ Cock \\ Valtiej Diaphragm \\ Valver Floal Operated \\ Gateryalve, Elcration \\ Gate Valve, P'lan}

Gatérylive, Molor Opersted

Angla.Gate. Valve, Elevatioa

Anglo.Giate Valve, Plan

GloFo Valve, Elevation

Gloto: Valive, Plan

Gloto:Valive, Motor Operated

Anglo.Globe Valve, Elevation

Angle Globe Valve, Plan

Valva; Lock and Shiold

Valverir Line

Waler Reguliating Valve, Prcsoure-Uperated

Valve; Quick Opening

Safety: Valve
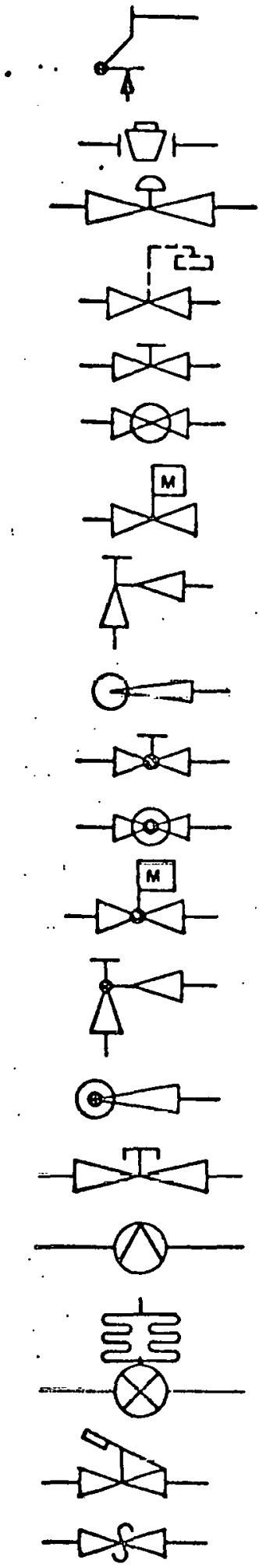

\begin{tabular}{lll}
\hline Filfinge: : & Planos scrom \\
\hline Bushing: & Feld \\
Crases: : &
\end{tabular}

Filtingo (Continued)
Elbow, $45^{\circ}$
Elbow, turned up
Elbow, turned down
Elbow, reducing

Elbow, Inng radius.

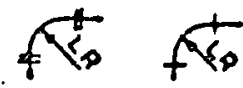

Elbow, double branch

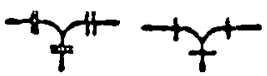

Elbow, eide outlet, outlet up

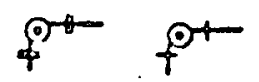

Elbor, side outlet, outlet dow'n

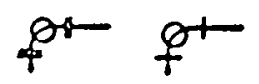

Flange, expansion joint

tEत -

Flange, reducing

Joint

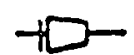

Redurer, connentris

Reducer, eccentric
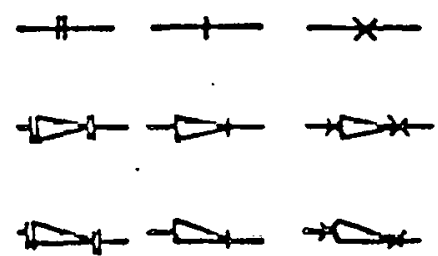

Sleove

Teo

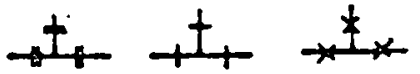

Tee, outlet up

HOt +Ot *OH

Tce, outlet down

Hor tet *A*

Tes, side outlet, outlet up

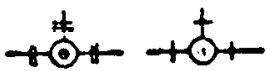

Tee, side outlet, oụtlet donn

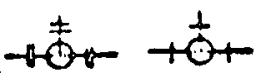

Tee, single owecp

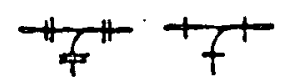




\section{Fillings (Continued)}

Tec, double owcep

Union

Lateral

Heafing

Air Eliminator

Anchor

Expansion Joint

Hanger or Support

Heat Exchanger

Hent Transfer Surface, Plan (Indicate Type Such as Convector)

Pump (Indicate Type Such as
Vacuum)

Strainer

Tank (Designate Type)

Propo

Boiler Return

Blast Thermostatio ...

Float

Flost and Thermostatio

Thermostatic

Unit Heater

(Centrifugal Fan), Plan

Unit Heater (Propeller), Plan

Unit Ventilator, Plan

Pumps

Pump, Servico

Pump, Aip

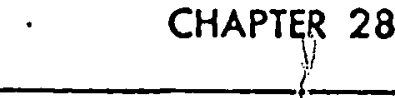

$\frac{\text { Flanoe serno }}{\text { Wdd }}$
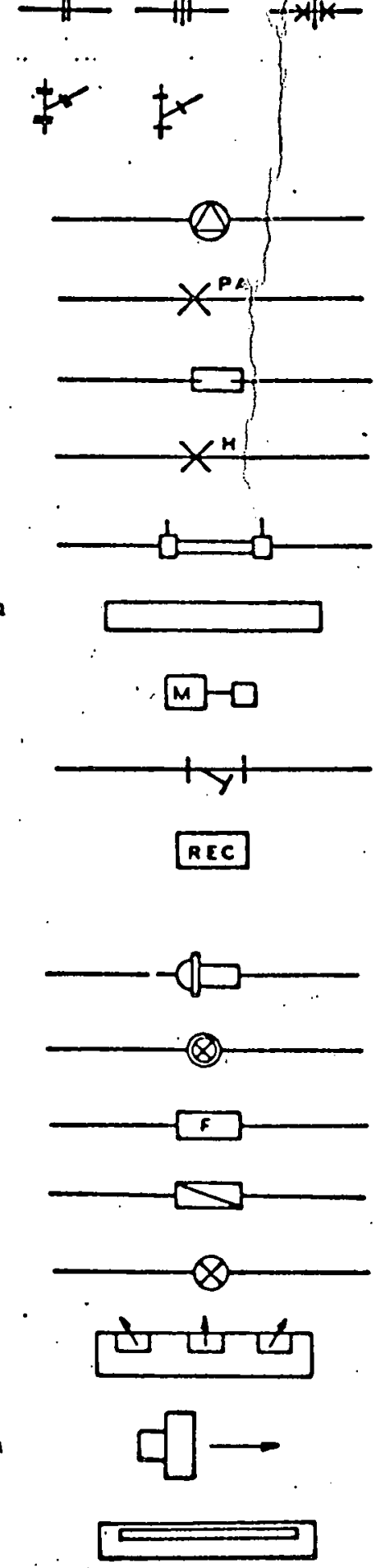

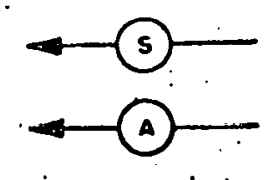

Punp, Circulating Water

Pump, Boiler Feed

Pump, Condensato

Pump, Reciprocating

Djnamic Pump, Air Ejector

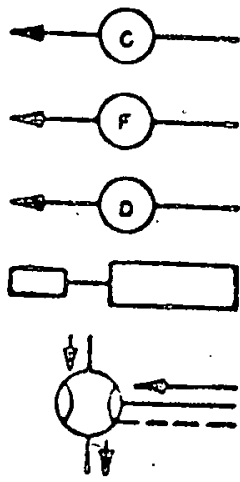

Air Circuloting Equipment

Fans and Ventilotorn

Fan and Molor with Belt Guard

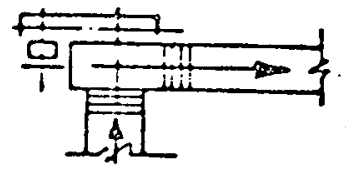

Unit Ventilstor, Plan

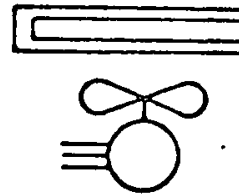

Duetwort

Direction of Flow

Duct, Width $\times$ Depth

Supply Duct, Section
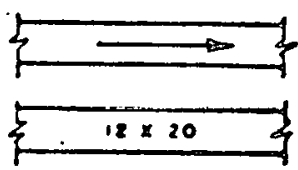

$\int_{-18 \times 20}^{5}$

Exhaust Duct, Section

Fresh Air Duct, Section

Recirculation Duct, Section

Other Ducts, Section

Inclined Rise, in Respect to Air

Inclined Drop, in Respect to Air

\section{Canvas Connection}
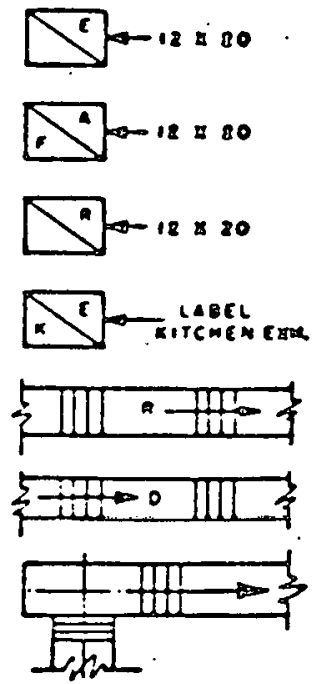

Adjustable Blank-of
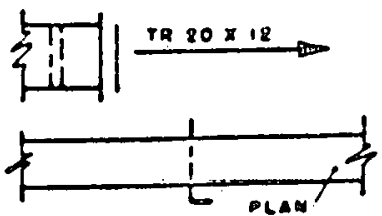

Volume Damper

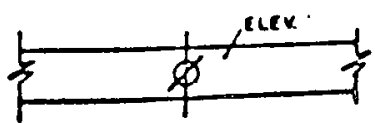


Automatic Damper

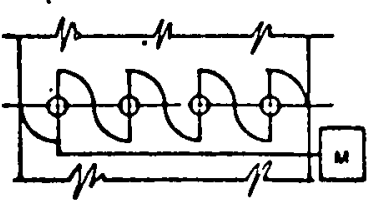

Deflecting Damper

Deflecting Damper Op

Deflecting Damper, Down

Vane
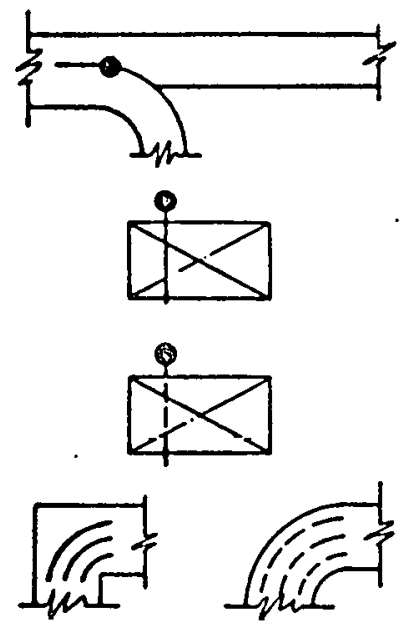

Grilles, Reghters, Diffusors, Etc.

Louver Opening

Intake Louvers and Screen

Adjustable Plaque
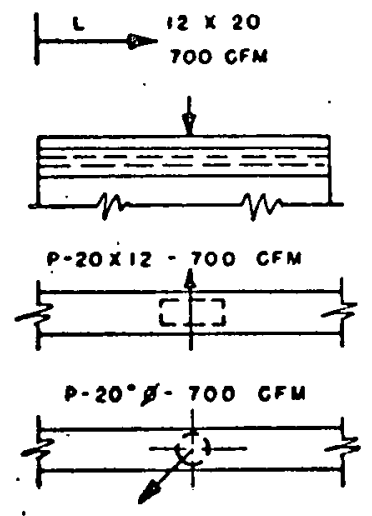

R.

Register

sirille

Top Register or Grille

Center Register or Grille

Bottom Register or Grille

Top and Bottom Register or

Ceiling Ilegister or Grille

Supply outlet

Exhaust inlet

\section{Compressors}

Comprosisors (pump only)

\section{Compressor}

Compressor, Finclosed Crankease, llotary, Belled

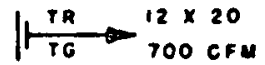

$\mid \frac{C R}{C G} \rightarrow \begin{aligned} & 12 \times 20 \\ & 100 \mathrm{cFM}\end{aligned}$

$\mid \frac{B R}{B 0}-\begin{aligned} & 12 \times 20 \\ & 700 \mathrm{CFM}\end{aligned}$

$\mid \frac{r+8 R}{T+80} 700 \mathrm{crm}$

$\forall \because \sqrt[c R]{C G} 12 \times 20$

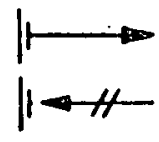

Coinpreasor, Open Crunkrake, lieciprocating, Helted

Compresanor, Opena Crunkraze. Reciprocating, Lirect Urive<smiles>CC1CCC1C</smiles><smiles>CC1=C(C)C(C)C=C1</smiles>

Motor Compressor Units

(oump ond molor only)

Motor-compressor, Fnrloand Crankcase, lleciprocating, Direct Drive

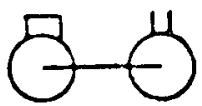

Motor-compressnt, Fneinerd Crnnke:ts: Reciprisutung, Bulted Drive.

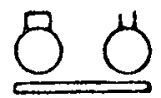

Motor-compreanen, Finrloued

Crankcasc, Loury, IJirect Dirvo

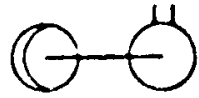

Motor-compressor, Sealed Crankcasc, Reciprocating

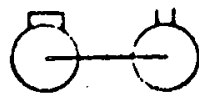

Motor-compressor, Sealed Crankcaso, rotary

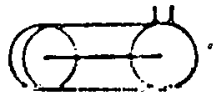

Condensing Unils loump,

molor, and condenserl

Condensing Unit, Air-Cocled

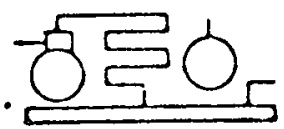

Condensing Unit. Wister-Cooled

Low Sides and Refrigeroted

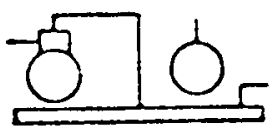
Fixfures

Low Sidos

Pipre ('nil

Evaporator, Plate Coil

Evaporator, Finned 'lype, Natural Convection

Evaporator, Manifululed, Baite Tube, Gravity Air

Evaporator, Manifoided, Finned, Gravity Air
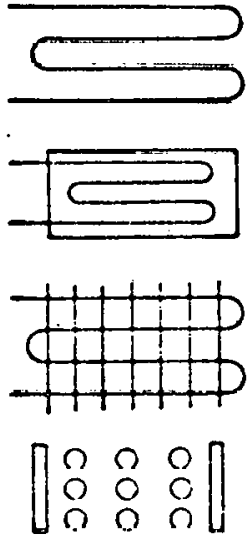

$\left[\begin{array}{l|l|l|l}0 & 0 & 0 \\ 0 & 0 & 0 & 1 \\ 0 & 0 & 0 & 1\end{array}\right.$

Evaporitori, Plate Coils, Headed or Manifolded

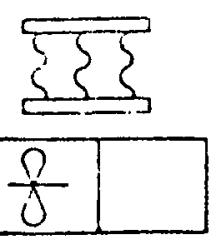

Evaporntor, Manifoldru, Finned forced Convection 

Evaporator, Circular, Ceiling
Type, Finned

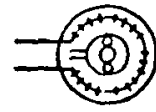

Evaporator. Domeatic or Ice Mraking Unit

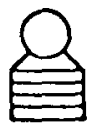

Immersion Cooling Unit

Uleat Transfer Surface, Plan

Water Chiller, Shell and Tubo

Brine Chiller, Shell and Tube

Rolflgoroled fixturos

Refrigerator, Above $32 \mathrm{~F}$

Display Counter

Frecer, Room

Ice Cream Cabinet

Beyerage Cooler

Drinking Fountain, Pedestal

Driaking Fountain, Trough Type

Drinking Fountain, Wạll Typo

Condensers, Cooling Towers, EtC. Condensere

Condenser, Air Cooled, Finned, Static Condenser, Air-Cosled, Finned,
Fnrced Air

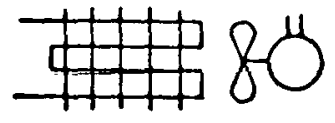

Condenser, Water-Cooled Sbell and Tubo

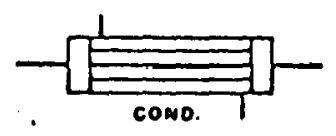

Condenser, Water-Cooled Shell
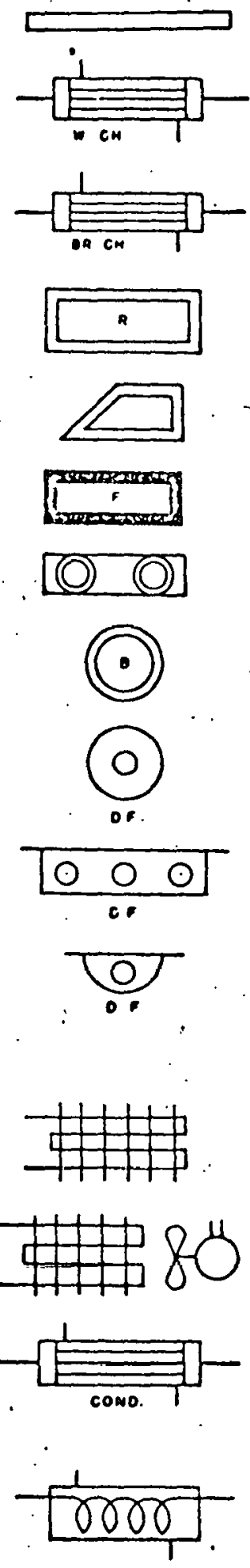

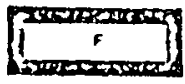
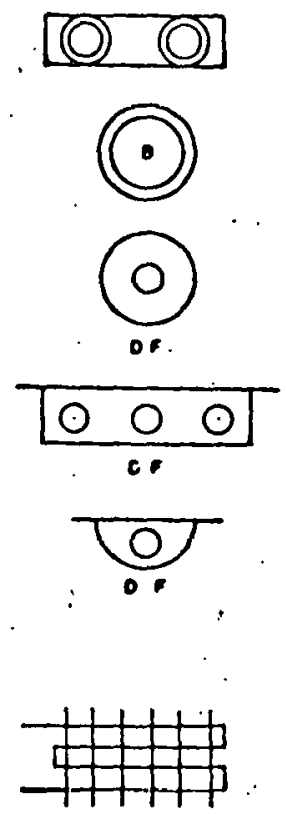

Condenser, Wnter-Cesoled, Concentric Tube in Tube

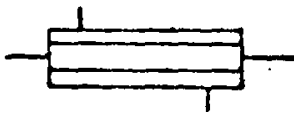

Condenaer, Fvaporativo

Cooling Towore

Cooling Tower

Spray Pond

Rocuivers

Receiver, IIorizontal

Receiver, Vertical

Miscelloneous

Open Tank

Closed Tank
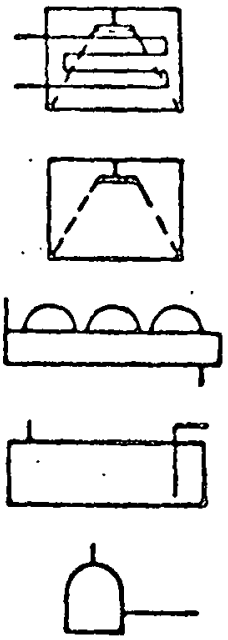

$\equiv \equiv \equiv \equiv$

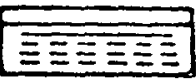

Motors and Other Power Sources oC Motore

DC Motor

DC Compound Mfotor or 2-uire Generator or Stabilized Shunt Mo:or

DC Series Motor or 2-wire Generator

DC Shunt Motor or 2wire Generator

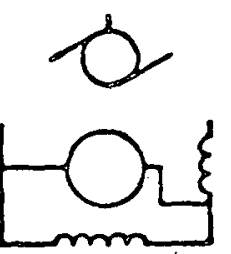

AC Motors

Repulsion motor

1-Phase Shaded Pole Motor

1-Phase Repulsion Start Indua tion Motor
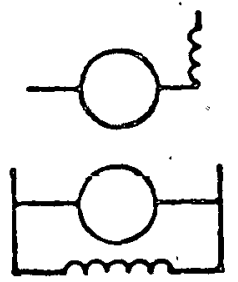

2-Phase 4-uire, or Single phase Split Phase Indurtion .Iotor or Cicticrator or Notary Pbaso Converter

3-phasn or 2-phase, 3-wire Squirrel Cince Induction Notor or Cencrutor
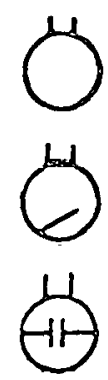

(4)

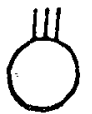


Abbreviations and Symbols

3-pinse Synchronous Motor or Generalor or Condenser

3-phnse Wound Rotor Indurtion Motor, Synrhronous Induction Motor, or Induction Cienerator

\section{Turbinas}

Steam Turbine

\section{Condensing Turbine}

\section{Controls}

\section{cofrigeront Confrols}

Copillary Tube

\section{Expansion Valve, Hand}

Expanision Valve, Automatic

Erpresision Valve, Thermostatic

Float Vulve, High Sido

Float Valve, Low Sido

Thermal Bulb

Golonoid Vnivo

Constant Pressure Valve, Suction

Evaporalor Presaure lengulating Valve, 'Thermostatic, 'Throlting

$$
\text { Type }
$$

Nuapmrator Pressure Reculating Gulve, Thernostitue, Snap detion

Evaporator Pressure Regulating Valve. Throttling Type, Evilporator Side

Compreasor Surtion Valve, Prespure I.muting, Throlting lype, Conipressior Side

Thermasuction Valvo

Srap Action Valvo

Check Valve, Liquid or Suction
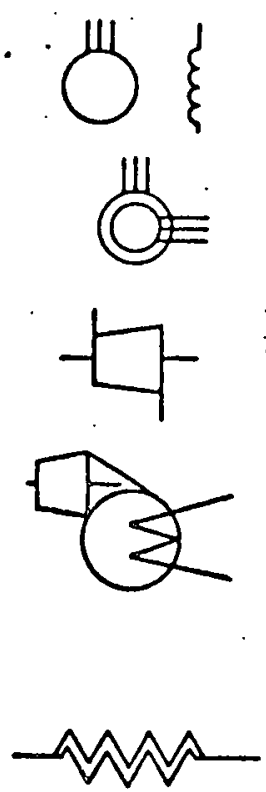

Automatic Reducing Valve

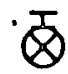

.. 8

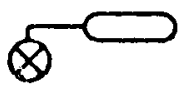

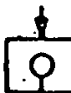
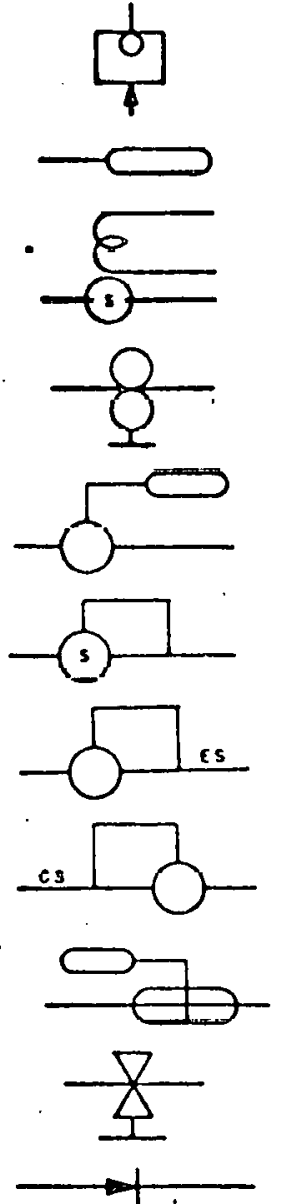

Tomperolure or Temperalure.

Thermostat, Self-contuined

Thermostat, Remotc Bulb

Pressure or Presiluure-Acluoled

Electrical or flow Contrals

Pressure Switch

Pressurestat sure Culoul Governor

Automntic Bypass Valve

Valve; Rizducing-pressure

Auxiliary Equipment

Rotrigeront

Filter

Strainer

Filter and Straioer

Scale Trap

Drier

Vibration Alsorber

Heat Fxchanget

Oil Separator

Sight Glıss

Fusible Plug

Rupture Diso
Actuated flectrical or Flow Controls

Pressure Switch with Iligh-I'res-

(i)

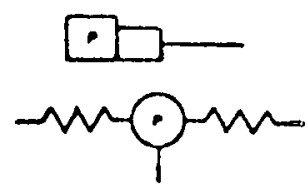

Automatic Valve Opersted by
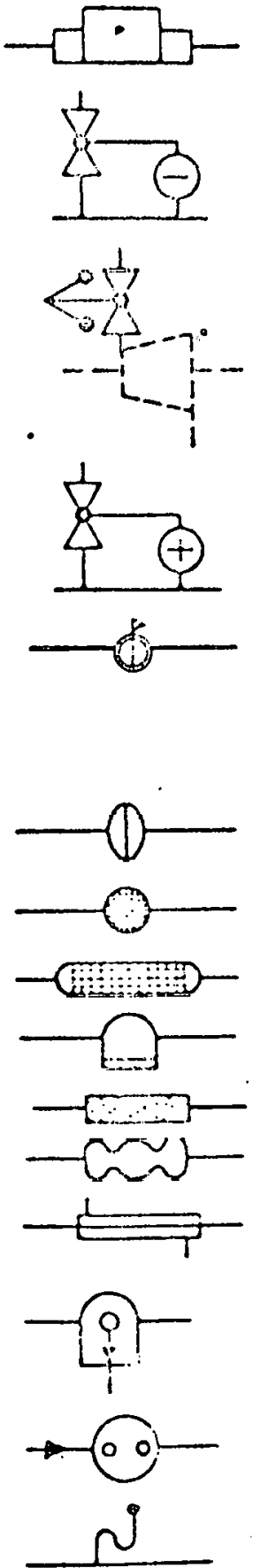

$\longrightarrow$ 
Bectided

Power Switcheo

Poxer Sritches, with Auxiliary Contucts, Normally Open

Disconnect Sritch

Fuse

Fuse, Current Responeive

Indicating Jights, Letters to Indicate Color:

Contact, Normally Closed

Contact, Normally Open

Contacla, Transfer, SPDT

Contact, normally open, with Time Closing Contact, Normally Closed, wịth
Time Opening

Batlery, general

Battery, polarity given

Batlery, one cell

\section{Copacitor}

Circuit breaker, 3-pole single-throw, nithout and with terminals

Circuit breaker, 3-pole doublethrow, without and with terminals

Coils, air core

Coils, magnet core

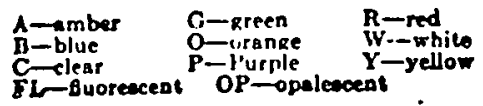

$0<-\frac{0}{\sigma}$
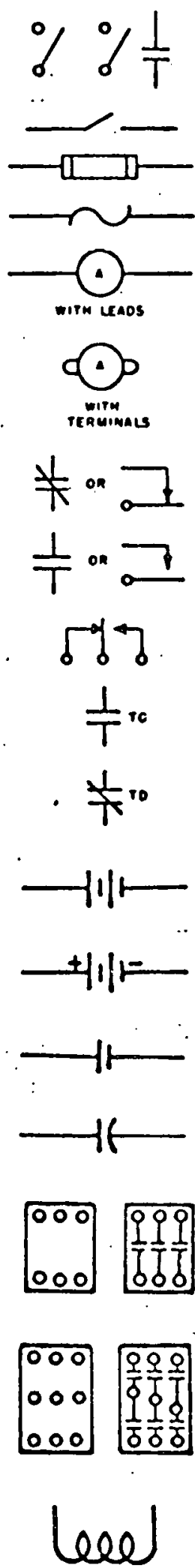

3
Resistor

Rclay, air core with normally open sritch

Relay, magnet core with normally closed owitch

Relay, overcurrent of overvoltage relay, I normally open contact

Relay, overload, having 2 current coils and 1 normally closed contact nith time opening

Relay, thermil overlosd, having 2 serics heating elcments and i nor. mally closed contact

Thermal overload with normally. closed switch

Contactor, 3-pole, manually operated. nithout blopiout coils

Contactor, 3-pole, electrically operated, with blowout coils, 2 normally open and 1 normally closed auxiliary contacts ated, with blowout coils, 2 normally open and 1 normally closed maio contacte and i normilly open auxiliary contact with time closing
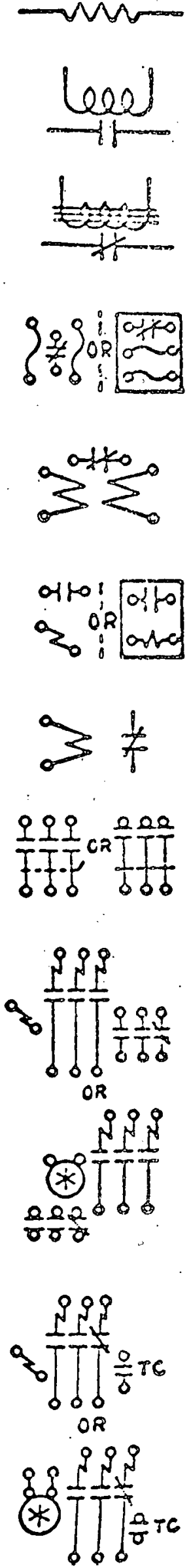
Contactor, double-throw, electrically operited, I wormally open and cal normally closed main contacts 1 normilly choserection: 3 normally open and I normilly closed auxiliary contacts, spring or gruvity retura

Conturtor, 3-poles, clectrically nperated with oil-immer-erl comblitets and

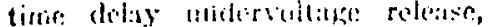
inrentansme trip from trip roil,

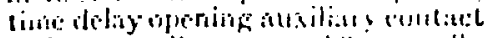
and 3 normally open and 3 hormally clescid unsiliary contuets with comwow points

Conevirtar, sinelia-pole, eloctrically

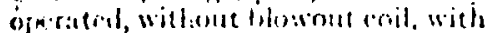

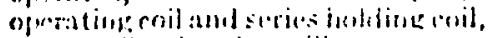
1 notmally slosed atusilisty contace

Gontactor, sinste.uphle, clectrically opreatcit, with bloitotit coul :amb 1 nnrmally open auxiliury coutact

Contartar, 2-pole, electrically nper-

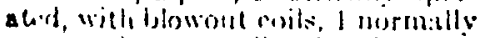
oncu and 1 normally closed auxiliaxy contaiclat

Contactor, 2 single-puld, eluctrim operated with olurertiag enils and bepteritely excitud blemente coils, hown mechanicalty interlosied

Contictor, nustipole, recetrically oixeraterf, with is mormilly opend and 2 notmally cluaded contucts.

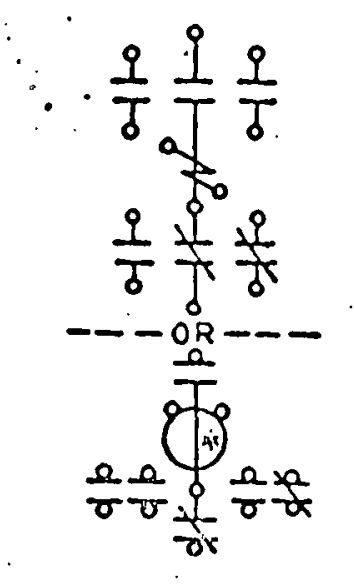

Contactor, double-throw, eiretrically opcrated, with 2 normatily open and 2 normally elosed main contacts with blowout crils und 2 normally open auxiliary contucts with a common connection

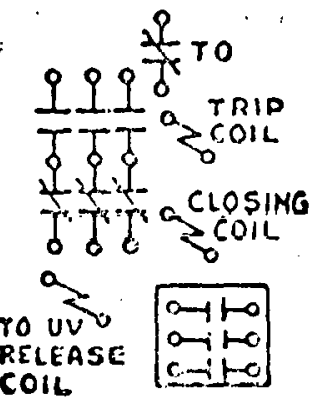

Alsrm, bell

Alarm, buzzer

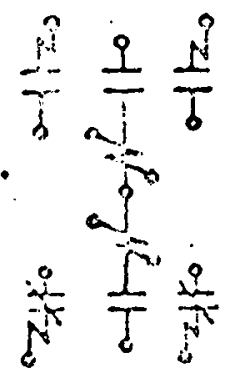

Alarm, annunciator
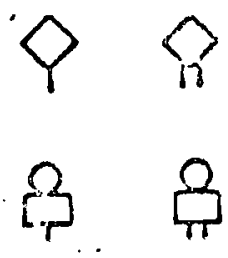

$[i$

Alsrm, horn<smiles>C1=C[Al]1</smiles><smiles>C1C2CN12</smiles>
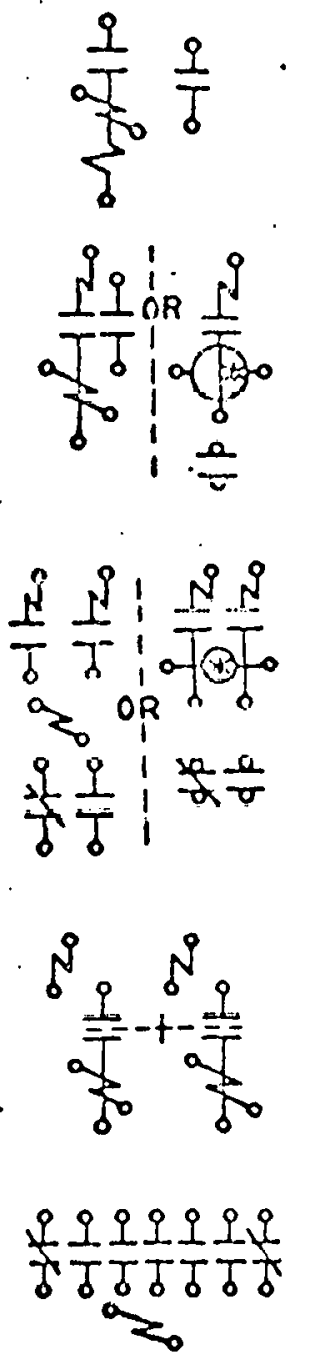

\section{Measurement \\ Indications of Mealure}

Square inclies

Square fect

Cubic feet

Pounds

Mensuring Deviens

Nieter

Cage

Thermometer

Thermocouplo

Ammeter

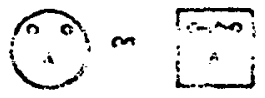

Voltmeter

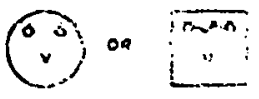

Wathour Meter

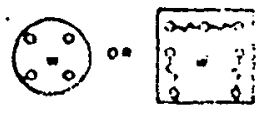

DC Wietliour Meter

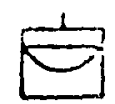




\section{IDENTIFICATION OF PIPING SYSTEMS BY COLOR}

The color schenc for identification of piping sustems, bașed on material carried, as listed in the following table and shown in Fig. 1, is reprinted from I'art V, Fifth Edition (1050), of the Engincering Standards of the Mechanical Contractors Association of America.

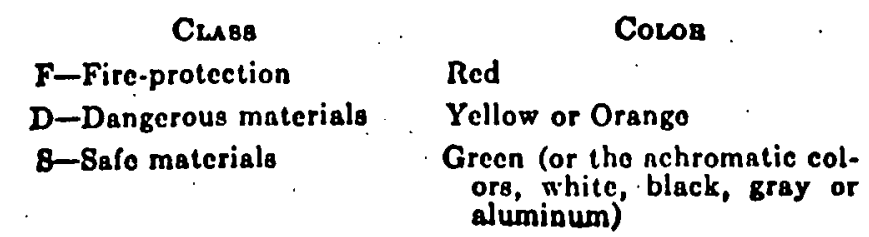

ond, when required

P-Protective materials Bright blue

V-Extra valuable materials Deep purple

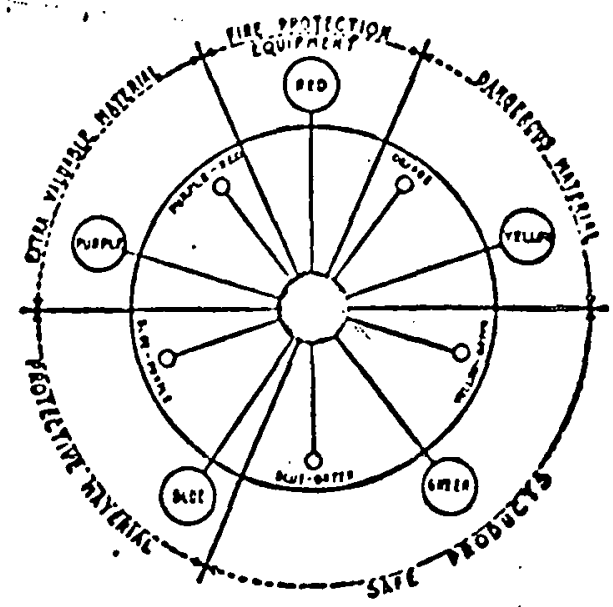

Fig. 1.... Main Classification by Color

THE GREEK ALPHABET

\begin{tabular}{|c|c|c|c|c|c|c|c|c|c|}
\hline . & $\begin{array}{l}A \alpha \\
B \beta \\
\Gamma \gamma \\
\Delta \delta \\
E_{E} \\
2 \zeta\end{array}$ & $\begin{array}{l}\text { Alpha } \\
\text { Beta } \\
\text { Gamma } \\
\text { Delta } \\
\text { Epsilon } \\
\text { Zeta }\end{array}$ & $\begin{array}{l}H \eta \\
\theta \vartheta \theta \\
I_{\theta} \\
K \dot{x} \\
\Lambda_{\dot{\lambda}} \\
M_{\mu}\end{array}$ & $\begin{array}{l}\text { Eta } \\
\text { Theta } \\
\text { Iota } \\
\text { Iiappa } \\
\text { Lambda } \\
\text { Mu }\end{array}$ & $\begin{array}{l}N y \\
\Xi \xi \\
00 \\
\Pi_{\pi} \\
P_{p} \\
\sum \sigma s\end{array}$ & $\begin{array}{l}\mathrm{Nu} \\
\mathrm{Xi} \\
\text { Omicron } \\
\mathrm{Pi} \\
\text { Rho } \\
\text { Sigma }\end{array}$ & $\begin{array}{l}T \varphi \\
T u \\
T_{\varphi \phi} \\
X x \\
\Psi \psi \\
\Omega_{\omega}\end{array}$ & $\begin{array}{l}\text { Tau } \\
\text { Upsilon } \\
\text { Phi } \\
\text { Chi } \\
\text { Psi } \\
\text { Omega }\end{array}$ & \\
\hline
\end{tabular}

